UNIVERSIDADE DE SÃO PAULO FACULDADE DE FILOSOFIA, LETRAS E CIÊNCIAS HUMANAS DEPARTAMENTO DE ANTROPOLOGIA PROGRAMA DE PÓS-GRADUAÇÃO EM ANTROPOLOGIA SOCIAL

\title{
ENTRE O ESPETÁCULO E A DEVOÇÃO: A FESTA DO DIVINO ESPÍRITO SANTO EM MOGI DAS CRUZES (SP)
}

Herbert Rodrigues

Dissertação apresentada ao Programa de PósGraduação em Antropologia Social da Faculdade de Filosofia, Letras e Ciências Humanas da Universidade de São Paulo, para obtenção do título de mestre em antropologia.

Orientador: Prof. Dr. John Cowart Dawsey

São Paulo

2006 
UNIVERSIDADE DE SÃO PAULO FACULDADE DE FILOSOFIA, LETRAS E CIÊNCIAS HUMANAS DEPARTAMENTO DE ANTROPOLOGIA PROGRAMA DE PÓS-GRADUAÇÃO EM ANTROPOLOGIA SOCIAL

ENTRE O ESPETÁCULO E A DEVOÇÃO:

A FESTA DO DIVINO ESPÍRITO SANTO EM MOGI DAS CRUZES (SP)

Herbert Rodrigues

São Paulo

2006 


\section{RESUMO}

Localizada às margens da grande metrópole paulistana, a cidade de Mogi das Cruzes realiza uma espetacular festa para o Divino Espírito Santo. Esta dissertação focaliza as formas expressivas de devoção que ocorrem na superfície da cidade e busca penetrar em camadas mais profundas da experiência dos devotos na tentativa de desvendar os elementos aparentemente arredios que surgem como força transformadora durante os dias de festa.

Palavras-chave: Divino Espírito Santo, devoção, expressão, experiência

\section{ABSTRACT}

Located on the edges of the great paulistana metropolis, the city of Mogi das Cruzes carries through a spectacular celebration for the Holy Ghost. This master thesis focuses the expressive forms of devotion that occur on the surface of the city and search to penetrate in layers deeper of the experience of the worshippers in the attempt to unmask the apparently timorous elements that appear as transforming force during the days of celebration.

Key Words: Holy Ghost, devotion, expression, experience 
MOGI DAS CRUZES: TERRA DE FESTA, TERRA DE RELIGIOSIDADE 16

A CIDADE: MOGI DAS CRUZES 20

A FESTA NA CIDADE 24

ASSOCIAÇÃO PRÓ-DIVINO: RELIGIÃO, CULTURA E EMPRESA 36

A CASA DA FESTA 40

O TRADICIONAL DISCURSO DA TRADIÇÃO 44

PERSONAGENS DEVOTOS 49

VIVA O DIVINO ESPÍRITO SANTO! 59

O DIVINO ESPÍRITO SANTO 64

EXPRESSÃO GERA EXPERIÊNCIA 70

as alvoradas 70

o milagre do pão 72

direções e olhares 73

as missas da novena 77

missa afro-brasileira 79

missa carismática 82

passeata das bandeiras 83

na tv 85

no jornal 85

na universidade 86

última passeata das bandeiras 86

A RELAÇÃO ENTRE PEDIDOS E GRAÇAS ALCANÇADAS 87

RUÍDOS E DESARRANJOS 94

ENTRE PALMITOS E PENTECOSTES: MONTAGENS E IMAGENS 99

A ENTRADA DOS PALMITOS 101

o cortejo 103

na fila do "afogadão" 108

o lugar da comida 110

ENTRE O SONO E A VIGÍLIA 117

A PROCISSÃO DE PENTECOSTES 118

o cortejo 119

a queima dos pedidos 125

MONTAGENS CRIADORAS DE IMAGENS

127

NHÁ ZÉFA: ENTRE A VIRGEM E A ONÇA

NHÁ ZÉFA: UMA MULIER FORTIS

VIRGEM MARIA: A MÃE DOS FRACOS

A VIRGEM E A ONÇA NO ESPELHO MÁGICO DA PERFORMANCE

132 


\section{INTRODUÇÃO}

Esta dissertação trata da festa do Divino Espírito Santo da cidade de Mogi das Cruzes (SP). O tema da pesquisa e seu objeto não são inéditos; muito já foi escrito e estudado sobre esse assunto nas ciências sociais. Conforme balanço realizado por Paula Montero (1999), o apogeu dos estudos sobre o catolicismo popular e suas festas se deu na década de 1970. Antes disso, na primeira metade do século XX, encontramos uma vasta produção bibliográfica sobre festas religiosas, sobretudo nos estudos de folcloristas, em que há um verdadeiro inventário das mais variadas manifestações populares no território nacional. Após esse período, não houve mais esforços de realizar trabalhos de maior fôlego que buscassem entender a religiosidade em outras bases e propor um novo olhar sobre a devoção popular. No 
entanto, essas festas, assim como outros fenômenos religiosos, ainda são observadas em diversos lugares do país e fazem parte da vida das pessoas.

O ponto de partida deste trabalho é um conjunto de debate sobre o assunto que será retomado, em sua maior parte, sob a perspectiva teórica de uma antropologia da performance e da experiência inspirada nos escritos de Victor Turner $^{1}$. Na busca de realizar um trabalho alinhado a esta perspectiva teórica, conduzimo-nos até a cidade de Mogi das Cruzes por conta de sua posição estratégica em relação à cidade de São Paulo (localizada às margens da grande metrópole), da religiosidade como motor da articulação de diferentes pólos em disputa, e das particularidades da festa do Divino Espírito Santo em Mogi das Cruzes no conjunto de outras festas no Brasil. Esta festa, conforme veremos nos quatro capítulos que compõem a dissertação, contém uma riqueza de significados (do ponto de vista antropológico) e concentra em torno dela formas de expressão (verbais e não-verbais), de reflexão e de representação do consciente e do inconsciente dos devotos, dos agentes e atores que dela participam. Assim, nossa problemática está em compreender as idiossincrasias dessa festa, o modo como cada papel é experienciado, como os eventos e os movimentos são vividos, como seus significados operam para a população devota e como imagens de elementos suprimidos irrompem na superfície da cidade nos dias de festa.

O problema inicial exigiu que nos situássemos concretamente no interior do grupo estudado, a partir de suas historicidades e particularidades, entendendo a cidade de Mogi das Cruzes como uma terra de religiosidade e festa. Em seguida, observamos as formas de expressão de devoção e a relação estabelecida entre os devotos e o Divino Espírito Santo. Além disso, analisamos de perto os cortejos e as procissões, o ato de peregrinar pela cidade, bem como os elementos aparentemente arredios que surgem durante a festa.

O foco deste trabalho recai numa festa localizada em um tempo e espaço específicos. O percurso que nos leva em direção à cidade de Mogi das Cruzes se inicia numa estação de trem no centro de São Paulo. Para se chegar ao destino, a

\footnotetext{
${ }^{1}$ As principais referências são The Anthropology of Experience (1986), coletânea publicada em parceria com Edward Bruner, e The Anthropology of Performance (1987).
} 
viagem urbana leva cerca de uma hora para atravessar parte da zona leste da capital e mais três cidades da Região Metropolitana de São Paulo (Ferraz de Vasconcelos, Poá e Suzano). Pela janela do trem percebe-se a paisagem mudar a cada quilômetro percorrido; ora a cidade se revela rica e exuberante, ora pobre e degradada. No vagão do trem, razoavelmente cheio, desfilam vendedores ambulantes que exibem suas mercadorias aos trabalhadores que retornam às suas casas e aos estudantes que freqüentam as universidades localizadas naquela cidade. Depois de uma baldeação na estação de Guaianazes (necessária para a continuação da viagem), chega-se à estação terminal de Estudantes em Mogi das Cruzes.

Tivemos a oportunidade de acompanhar a festa do Divino Espírito Santo em Mogi das Cruzes em quatro ocasiões. A observação empírica teve como ponto de partida os deslocamentos das pessoas nos espaços da cidade que nos levaram para o interior da festa, como as alvoradas, as passeatas das bandeiras, a entrada dos palmitos, a procissão de Pentecostes etc. Entre os interlocutores de pesquisa, buscamos identificar quem produz as narrativas, quem monta o contexto, quem dá sentido àquilo tudo, ao que é lembrado e ao que é esquecido. Deixamos os sujeitos falarem na busca de documentar o não-documentado da realidade social.

Diante disso, a etnografia tornou-se central na análise. Ela nos auxilia a descobrir os sentidos empregados nos múltiplos eventos da festa. Vale dizer que nossa interpretação não se dissociou daquilo que concretamente acontece na cidade durante os dias de festa. A observação, a descrição, a postura do pesquisador em campo, o diálogo com os interlocutores, os dados históricos e a estratégia narrativa buscaram compreender os lugares de transformações e as tensões não resolvidas na festa de Mogi das Cruzes. Com o trabalho de campo aprendemos que na vida social os principais enigmas não são decifrados apenas no que é dito, mas também no nãodito, no que muitas vezes está silenciado e suprimido. Daí a importância de empregar uma análise que privilegiasse o uso dos corpos, dos gestos e da linguagem expressiva.

Muitas vezes o que se ganha na descrição, perde-se na interpretação. De qualquer maneira, tentamos descrever e interpretar de modo equilibrado, sem muitos prejuízos na compreensão, pois entendemos que "fazer etnografia é a tarefa 
de quem conta a história daquilo que foi ou que está prestes a ser esquecido" (Dawsey, 1998, p.67).

Portanto, a etnografia apresentada consiste numa crítica etnográfica cujos dados qualitativos trazidos do campo indicaram os possíveis caminhos de interpretação percorridos. Caminhamos por vias que buscaram entender a história da festa, sua configuração, seus corpos e sentimentos. As representações e percepções estéticas dos devotos formaram a matéria-prima deste trabalho.

A importância da pesquisa de campo está no fato de expor e desvendar algumas incoerências de trabalhos que trataram do tema em outros momentos. Mais do que fazer uma alusão ao universo pesquisado, propomos uma problematização teórica articulada à etnografia. Assim, a ordem de apresentação dos dados empíricos não seguiu necessariamente a ordem em que estes apareceram na seqüência dos acontecimentos da festa. Seguiu, por um lado, a ordem de representações dos sujeitos e, por outro, a estratégia de nossa narrativa na medida em que elucidava as questões colocadas.

Para Walter Benjamin, "método é caminho indireto, é desvio" (1984, p.50). Há nessa formulação afinidades com a antropologia de Victor Turner que sugere um "desvio metodológico" ${ }^{2}$ em relação aos procedimentos consagrados por Radcliffe-Brown e outros representantes da Antropologia Social Britânica. Esse "desvio" consiste em compreender a vida social a partir daquilo que se encontra às margens, ou seja, acentua as possibilidades de investigação encontradas no limbo da vida social.

Ao longo dessa dissertação, as questões teóricas foram incorporadas à discussão por meio dos dados etnográficos. Os aspectos etnográficos ocupam uma posição central. Em segundo lugar, entram os aspectos interpretativos. $\mathrm{Na}$ introdução há uma breve discussão teórica que ilumina o texto como um todo.

2 Para uma problematização da idéia de "desvio metodológico" em Victor Turner, ver especialmente Dawsey (2000; 2005a; 2005b). 
Nesse primeiro momento, apresentamos os principais conceitos e noções da antropologia da experiência e da performance que nos ajudaram a conceber o trabalho. Nas considerações finais, retomamos a questão do catolicismo popular para saber até que ponto contribuímos para compreendê-lo melhor. Como últimas palavras, buscamos realizar uma síntese teórica dos capítulos. Na tentativa de construir um texto "leve", sem muitas citações longas, segue um anexo com os principais cantos e orações executados na festa.

Como ponto de partida, consideramos o principal questionamento da antropologia de Victor Turner que consiste em problematizar o modo como as sociedades se constituem, se mantêm, resolvem suas pelejas e se renovam. Para o autor, as sociedades são responsáveis por inaugurar os momentos de crise, que são programados para que as mesmas se revitalizem. Assim, não há como entende-las apenas através da estrutura observável: é preciso encontrar sua fonte de constituição indo às margens, àquilo que não está documentado e problematizar o que está de fora dos processos políticos e econômicos hegemônicos.

Turner lança mão de importantes conceitos e noções para pensar suas questões. A noção de liminaridade, nesse sentido, é teoricamente importante para compreender as relações sociais, pois a centralidade é algo construído e delimitado, constantemente sob o risco de ser desmontada. A idéia de liminaridade não está somente nos processos de transição, mas também nos fenômenos marginais e antiestruturais, ou seja, essa noção é generalizada, perpassa todos os fenômenos sociais e culturais e não apenas os ritos de passagem como se convencionou pensar. A liminaridade é o que há de comum em todos os fenômenos transformadores.

O conceito de drama social é central na discussão de Victor Turner conforme podemos observar em diversos trabalhos (1974a; 1974b; 1982; 1996). Seguindo o modelo elaborado por van Gennep sobre os ritos de passagem como uma seqüência de três estágios - separação, transição e reagregação -, o drama social consiste em um modelo com quatro fases que se desenvolvem de forma processual. São elas: 1. quebras ou rupturas, 2. crise, 3. ação reparadora, e 4. reintegração ou desfecho.

O drama social representa uma fase do processo de contestação evidente em todos os níveis de organização social que surge em situações de conflito. Para 
Turner, o drama social, gerado nos momentos de ruptura da vida social de um grupo, é um tipo específico de unidade de experiência. Tais cismas derivam geralmente de uma série de questões sociais não resolvidas que irrompem em conflitos. Essas erupções formam dramas sociais cujo processo segue as quatro fases de desenvolvimento.

A noção de drama social foi muito criticada, principalmente por Clifford Geertz que a chamou de "uma fórmula para todas as estações" (2004, p.46). Reconhecemos a relevância da crítica de Geertz; no entanto, nessa dissertação, o drama social não é uma fórmula, mas uma luz que ilumina o material etnográfico em diversos momentos dado que o drama social é essencial para a formulação da antropologia da performance. Victor Turner não entende a performance como uma seqüência de papéis desempenhados por indivíduos ou grupos, mas o resultado da suspensão de papéis. Sendo assim, o drama social, como uma irrupção ao nível da superfície de questões não resolvidas da vida social, torna-se reflexivo e expressivo. A partir dos dramas sociais derivam os gêneros de performance.

A performance para Turner (1987) é uma forma de expressão reflexiva, um modo de brincar com o perigo, ou seja, aquilo que "é" vira "como se" e ocorre numa seqüência complexa de ação. Para ele, a matéria básica da vida social é a performance. Ela é o paradigma do processo social, uma espécie de arte aberta, interminável, descentralizada e liminar. A performance não seria meramente o "reflexo" da configuração cultural ou do sistema social, mas uma forma reflexiva e freqüentemente crítica de escancarar as idiossincrasias de uma sociedade. Através do "espelho mágico" (Turner, 1987, p.22), cuja imagem refletida é irradiada de um a outro, o significado total da performance emerge da união dos papéis e da relação entre os atores e o público num certo momento dos processos sociais - geralmente em áreas indeterminadas e ambíguas - subjacentes ao grupo. A performance é o olho pelo qual uma sociedade vê a si própria.

Richard Schechner, um dos principais interlocutores de Victor Turner, fala em termos de uma "seqüência total da performance" (1985). Essa seqüência total possui vida própria, ou seja, ação e conservação da ação coexistem no mesmo evento. Para Schechner, a performance tem o poder de transformar, gerar empatia, 
causar espanto e provocar efeitos lúdicos e/ou críticos sobre atores e espectadores. A performance é o lugar de transformação do ser e da consciência, ou seja, o "não-eu" vira "não não-eu" (Dawsey, 2004). Segundo Schechner, as fases de uma seqüência total da performance consistem em: treinamento, oficinas, ensaios, aquecimento, performance propriamente dita, esfriamento e desdobramentos. Schechner, ao dividir a performance em fases, realiza uma analogia em relação aos ritos de passagem descritos por van Gennep: 1. separação (treinamento, oficinas, ensaios e aquecimento); 2. transição (performance propriamente dita - estado liminar); e 3. reagregação (esfriamento e desdobramentos). Essa analogia permite a Richard Schechner estabelecer pontos de contato entre o ritual e o teatro.

Da mesma maneira, Victor Turner, a partir do conceito de drama social, estabelece uma conexão entre a antropologia e o teatro que, conseqüentemente, contribui para sua antropologia da performance. Para o autor, o mundo não é um palco, como diria Goffman, mas as fases dramatúrgicas surgem quando a crise irrompe no fluxo da vida social ordinária. A performance é a manifestação social par excellence.

As experiências são partilhadas através da participação nas expressões culturais e nas performances que não são meros reflexos da sociedade, mas metacomentários. A experiência, segundo Turner (2005), a partir de Dilthey, chega até nós não apenas verbalmente, mas por imagens e impressões. A experiência se refere a uma atividade do eu para com os seres humanos não apenas dos que estão envolvidos nas situações, mas nas expressões. A relação de articulação da experiência se dá através da performance. Os participantes de uma performance partilham uma experiência comum. A performance é, portanto, a realização de uma experiência.

Em resumo, a antropologia da performance, como parte da antropologia da experiência, vê as pessoas como agentes ativos de um processo histórico que constrói seu próprio mundo. A experiência do mundo sensível se dá em choques que evocam imagens do passado e dão um colorido especial e novos contornos ao presente. A experiência incita a expressão e a comunicação, afinal, "somos seres 
sociais e queremos dizer o que aprendemos com a experiência" (Turner, 2005, p.180).

A antropologia da performance e da experiência, nesse sentido, são importantes para iluminar nosso material etnográfico, pois o estudo de uma festa envolve diversas unidades constitutivas da vida social como os corpos, os ritmos, as danças, os sons, as cores, os movimentos, a iconografia etc. A "festa total" apresentada aqui é um momento de performance.

Os devotos estão envolvidos totalmente naquilo que fazem através do "fluxo", noção que Victor Turner (1982) tomou emprestado de Csikszentmihalyi, isto é, uma sensação holística presente no momento em que agem em conjunto, mas que acontece no indivíduo e não entre os indivíduos, conforme lembra Dawsey (2005a). Num livre fluir das emoções, as pessoas se sentem envolvidas por um sentimento comum e livre das amarras sociais. Ao estarem juntos, a palavra operativa é o "ser" e não o "fazer". Para Turner, "todos os homens, e até mesmo todas as coisas, são sentidos como um todo, subjetivamente, na experiência de fluxo" (1982, p.57, tradução minha).

Entre o espetáculo e a devoção nos remete ao movimento que vai do liminar ao liminóide exposto num artigo de Victor Turner, do livro From Ritual to Theatre (1982), em que o autor compara sistemas simbólicos de sociedades pré e pósindustriais. Os fenômenos liminares seriam aqueles localizados supostamente às margens e de caráter ambíguo; os liminóides seriam o modo como as sociedades modernas se apropriam desses fenômenos e os transformam em produtos de consumo voltados para um público interessado (o "-óide" vem do grego -eidos, uma forma, um modelo, e significa "semelhante", ou seja, "liminóide" é semelhante sem ser idêntico ao "liminar").

Nas sociedades pós-industriais, os elementos liminares foram reduzidos a gêneros de entretenimento. Fenômenos artísticos, esportivos e religiosos se transformaram, nas "sociedades complexas", em atividades optativas, ou seja, livres de obrigações e constrangimentos. Nas sociedades modernas coexistem ambos os fenômenos numa espécie de pluralismo cultural. Para Turner, “a opção está impregnada nos fenômenos liminóides, a obrigação impera nos liminares" (1982, 
p.43, tradução minha). Para algumas pessoas, o liminóide é sentido como mais livre do que o liminar, uma questão de escolha e não de obrigação. Para o autor, “o liminóide é como uma mercadoria - na verdade, é uma mercadoria, que se seleciona e se paga -, mais do que o liminar, que exige lealdade e está colado aos membros ou aos desejos dos membros de grupos corporativos. Um trabalha para o liminar, o outro brinca com o liminóide" (1982, p.55, tradução minha).

Para Victor Turner, “os gêneros pretensamente de 'entretenimento' da sociedade industrial são freqüentemente subversivos, satíricos, fazem chacotas, são burlescos, ou sutilmente colocam abaixo os valores centrais do essencial, a esfera do trabalho da sociedade, ou pelo menos os setores selecionados daquela sociedade" (1982, p.41, tradução minha). Portanto, “o artista solitário cria o fenômeno liminóide, a coletividade experiencia símbolos liminares" (Turner, 1982, p.52, tradução minha).

Assim, procedendo à maneira de Victor Turner, buscamos no espetáculo o lugar privilegiado para observar os momentos de performance em que a sociedade brinca com o perigo, aproveitando-se do caos, que se manifesta no limen, para revitalizar o cosmos e assimilar os processos sociais. As propostas teóricas de Victor Turner propiciam uma narrativa entrelaçada entre o nosso objeto de estudo e a problemática teórica. Propicia, fundamentalmente, um diálogo entre o espetáculo e a devoção. As formulações de Victor Turner permitem-nos um duplo deslocamento: é preciso ir às margens das margens, pois eventos e figuras liminares são a garantia da vitalidade de vida social.

Ao modo do arqueólogo, que busca nos restos e resíduos de materiais descartados a compreensão de uma sociedade do passado ou que está prestes a ser esquecida, procuramos no emaranhado da vida social escavar as camadas de acontecimentos da festa do Divino Espírito Santo em Mogi das Cruzes. Para o arqueólogo, o trabalho de escavação é uma atividade lenta e minuciosa que envolve o registro e a análise de vestígios encontrados no sítio arqueológico. Para o 
antropólogo não é diferente. Estudar os fenômenos sociais exige um parcimonioso cuidado na apresentação dos dados empíricos e na análise teórica.

O procedimento arqueológico nas ciências humanas evoca inevitavelmente a figura de Michel Foucault. O filósofo francês pensava numa arqueologia do saber para desvendar a produção do discurso como efeito de verdade. Outros autores também utilizaram a arqueologia como um paradigma, entre eles, Walter Benjamin, Marcel Mauss, Clifford Geertz e outros. O paralelo estabelecido com a arqueologia nessa dissertação é meramente estilístico. Trata-se apenas de uma forma de apresentar os capítulos ao modo de uma escavação em direção àquilo que se encontra submerso nas camadas profundas de uma sociedade. Busca-se "transcender a observação empírica e alcançar realidades mais profundas" (LéviStrauss, 1974, p.21). Assim, procuramos nas margens, nos espaços ambíguos, no suprimido, soterrado e esquecido as fontes vitais que nutrem a existência de uma população devota.

Seguiremos em direção àquilo que se encontra soterrado abaixo da fina camada da superfície para abrir subterrâneos e explorar desvios. Poderíamos dizer que cada capítulo corresponde a uma camada.

No primeiro capítulo - a primeira camada - apresentamos a festa do Divino Espírito Santo no plano da superfície. A partir da apresentação de um museu barroco da cidade mergulhamos na abertura da festa e identificamos os usos inventivos da tradição por parte dos agentes produtores da festa que se reúnem sob o teto de uma instituição leiga. Através da análise daquilo que fazem e daquilo que dizem sobre o que fazem foi possível desvendar algumas rupturas e descontinuidades na construção discursiva sobre a origem da festa na cidade. Agrupamos a vizinhança de certos elementos estabelecendo relações e especificidades numa cadeia de acontecimentos, articulando etnografia e história, entrecruzando eventos sem reduzi-los a um esquema linear.

No segundo capítulo - a segunda camada - penetramos em estratos mais profundos por meio da etnografia compreendendo, num primeiro momento, um certo movimento regular de expressão da devoção como um simples levantamento de mastro. Num segundo momento, recuamos na história e na teologia para saber o 
que é o Divino Espírito Santo. Em seguida, descrevemos a relação entre pedidos e graças alcançadas (central na formulação da devoção) e deixamos os sujeitos falarem sobre o poder transformador do Espírito Santo. Ao final, apresentamos quebras e rupturas no interior da festa que surgem em forma de ruídos.

No terceiro capítulo - a terceira camada - discutimos dois eventos realizados numa área espaço-temporal circunscrita na cidade de Mogi das Cruzes e protegida por lei como "patrimônio cultural e paisagístico". Este capítulo trata fundamentalmente do cortejo da entrada dos palmitos e da procissão de Pentecostes, que ocorrem respectivamente no sábado e no domingo de encerramento da festa. Além disso, falamos do lugar da comida na festa e de montagens criadoras de imagens.

No quarto capítulo - a última camada - tratamos do suprimido, de algo soterrado e esquecido que está fora dos cânones oficiais da festa e irrompe como força revitalizadora da superfície. Apresentamos uma mulher chamada Nhá Zéfa Onça e Nossa Senhora como personagens brechtianos. Resgatamos algumas notas biográficas de Nhá Zéfa captadas na etnografia para falar sobre as esperanças depositadas pelos devotos em Nossa Senhora. Da mesma maneira, recuperamos na história e na antropologia a imagem da Virgem Maria como figura mediadora entre os donos do poder e as classes subalternas (a grande mãe dos filhos bastardos). Ao final, colocamos a Virgem e a Onça de frente ao espelho mágico da performance para compreender como ocorre a irrupção de estratos profundos do universo social na superfície de uma cidade.

O fazer antropológico hoje em dia (talvez desde sempre) é uma experiência no sentido etimológico da palavra, conforme ressalta Victor Turner, derivada do indo-europeu per, que significa "tentar, aventurar-se, arriscar" e se relaciona ao cognato germânico que remete à "passagem", ao "medo", ao "transportar-se", que em latim também significa "passar através", com implicações em ritos de passagem. Aqui, estamos correndo riscos. 


\section{MOGI DAS CRUZES: TERRA DE FESTA, TERRA DE RELIGIOSIDADE}

Ao observar a cidade de Mogi das Cruzes nos dias de hoje, temos uma sensação parecida com a de Clifford Geertz quando falou da Indonésia na década de 1970 cujos "artefactos de diferentes camadas de um local arqueológico há muito ocupado, ao serem espalhados sobre uma mesa, resumem num relance milhares de anos de história humana" (Geertz, 1980, p.13). Assim, com os olhos voltados para os fragmentos de uma cidade localizada às margens da grande metrópole paulistana, 
observamos Mogi das Cruzes, que se formou em torno de um aldeamento indígena durante o período colonial em meados de 1560. Os livros de história da cidade contam que o povoado começou a crescer em 1601 com a chegada do colonizador Gaspar Vaz, que abriu os primeiros caminhos de acesso a São Paulo. Em 1611, o pequeno aldeamento tornou-se vila. No ano de 1633, foi construída a igreja da Ordem Primeira do Carmo e, em 1762, construiu-se a igreja da Ordem Terceira do Carmo.

Atualmente, nas dependências dessas igrejas está instalado o Museu das Igrejas do Carmo com peças de arquitetura, pinturas a óleo e esculturas do barroco e do rococó. Ao caminharmos pelo museu encontramos, na primeira sala, peças de ornamentos com anjos, mensageiros, altares e oratórios feitos em madeira policromada. Na segunda sala, há peças sobre a família de Jesus como a anunciação, Nossa Senhora do Ó, Nossa Senhora do Leite, São Joaquim, Santana, São José, Santa Emerenciana, São João Batista, também esculpidas em madeira e barro. Na terceira sala, há elementos sobre a difusão do cristianismo no mundo, imagens de Nossa Senhora do Carmo, Santa Bárbara, Nossa Senhora do Rosário, São Bento, São Francisco de Assis, São Domingos e telas representando a Paixão de Cristo.

Neste museu estão depositadas imagens fragmentadas de difícil compreensão e interpretação que impressionam os sentidos do observador pelo predomínio da dramaticidade nos contrastes entre as formas visuais. Nas obras barrocas há um predomínio do emocional sobre o racional que buscava atingir a fé através dos sentidos, tratava-se de um modo de ver, sentir e relacionar a arte e a fé. Pois, como sabemos, o estilo barroco traduz uma tentativa de articular forças antagônicas como o bem e o mal, o céu e a terra, a pureza e o perigo, a alegria e a tristeza, o pró e o contra, o espírito e a matéria.

Para Maria Lúcia Montes (1998a), encontramos no barroco uma “infinidade de projeções". O espírito barroco reúne, ao mesmo tempo, o erudito da arte sacra e o profano e orgiástico das celebrações populares. O barroco brasileiro agrega algo de extravagante e grotesco, mas também algo pleno de riqueza e significado, que, ao 
ser explorado, releva camadas profundas de nossa história e mentalidade. Para além da compreensão do barroco como instrumento de doutrinação cristã no Brasil, sua herança simbólica nos propicia penetrar nas profundidades de nossa cultura, pois “o que a designação de barroca assinala talvez seja, antes de tudo, uma forma de sensibilidade e uma visão de mundo que, no caso brasileiro, conformam, na longa duração da História, o ethos de uma cultura desde os primórdios da nossa formação" (Montes, 1998a, p.144, grifos da autora).

Descolando-se do Museu das Igrejas do Carmo em direção a uma praça central da cidade, saímos do museu barroco e encontramos o império do Divino Espírito Santo (uma espécie de metáfora barroca) montado e ornamentado em uma cabana especialmente levantada para os onze dias de festa do Divino, na praça da catedral de Santana. Essa capela é renovada a cada ano sob a orientação do festeiro e com execução de artistas plásticos. Na porta revezavam, 24 horas por dia, dois soldados do Tiro de Guerra em posição de guarda durante os dias de festa.

No interior do império do divino ficam guardadas as bandeiras do festeiro e do capitão do mastro, além da coroa e do cetro, que sempre estão nas mãos das respectivas esposas em todas as procissões da alvorada e das passeatas noturnas das bandeiras. Ainda no interior desse recinto, a imagem do Divino Espírito Santo, a pomba, está colocada num oratório de madeira emprestado do museu barroco. Ao lado desse oratório, que ficava apoiado numa base de ferro, anjos e castiçais também vindos da igreja barroca. Em frente, o genuflexório, onde as pessoas se ajoelhavam e rezavam o dia todo. Antes da saída, havia uma mesa com papéis e canetas para que se pudessem fazer os pedidos e duas caixas ao lado, uma para colocar os pedidos e outra as doações em dinheiro.

A desmontagem do museu e a remontagem a cada ano do império do divino consistem numa justaposição de imagens fragmentadas e arbitrárias que relaciona épocas e contextos diferentes. Há algo fossilizado na festa do Divino de Mogi das Cruzes que identifica na "fisionomia de uma 'outra' época, a do seu tempo" (Bolle, 1994, p.109). Willi Bolle discute a noção de historiografia alegórica de Walter 
Benjamin apresentada no livro Origem do drama barroco alemão relacionando os contornos e entrelaçamentos entre a alegoria barroca e a alegoria moderna. Para Benjamin, diz Bolle, a alegoria barroca é uma forma caótica e fragmentária de sobrepor diferentes camadas sedimentadas de história num mesmo tempo, assim como a alegoria moderna que combina simultaneamente fragmentos inesperados e paradoxais.

A alegoria barroca busca preservar em forma de "ruído" a memória daquilo que está prestes a ser esquecido. De modo que interpretar a relação entre o museu barroco e o império do divino "é ingressar nas ruínas de uma época em outra, ruínas que se convertem na permanência inconsciente de uma época em outra" (Matos, 1998, p.44).

Tensão de elementos contrários, portanto, marcam as épocas, os movimentos artísticos, o pensamento e a religiosidade. Fragmentos inesperados e antíteses incompreensíveis estão presentes na abertura da festa do Divino Espírito Santo em Mogi das Cruzes que ocorre na quinta-feira da Ascensão, dia em que se iniciam as festividades. A solenidade de abertura conta sempre com a presença do bispo diocesano de Mogi das Cruzes, do prefeito da cidade, dos casais de festeiros e capitães do mastro, além de outras autoridades reunidas num palanque em frente ao império do divino. Na praça, diante desse palanque, os devotos aguardam do bispo a benção de suas bandeiras. Bandeiras dos devotos abençoadas, bandeiras da cidade, do estado de São Paulo e do Brasil hasteadas, os casais de festeiros e capitães do mastro, juntamente com os devotos, seguem em procissão para um lugar chamado Centro de Integração Profissional Deputado Maurício Nagib Najar onde é realizada a quermesse. Assim, temos a abertura "oficial" (as aspas são por conta do caráter oficialesco que gira em torno deste cerimonial) da festa do Divino Espírito Santo.

Nesse mesmo local são montadas várias barracas que servem comida e bebida, além de algumas barracas de publicidade e de uma tenda, onde artistas 
plásticos da cidade expõem obras sobre o Divino Espírito Santo ${ }^{3}$. Esse lugar se divide em duas partes: uma interna e outra externa. Na parte interna, são servidos o yakissoba, o "afogado" e os caldos. Na parte externa, ficam as barracas de publicidade (incluindo os patrocinadores, um jornal e um canal de televisão local), cerca de quatorze barracas de comida (que servem doces, bolos, salgados, pão de queijo, pizza, pastel, crepe, tempurá, yakitori, fogaça, sanduíches, churrasco, entre outros) e três com bebidas (com cerveja, refrigerante, sucos de fruta e choconhaque). Há também um bingo beneficente, os caixas para a compra de fichas com os valores dos produtos, a tenda da mostra de arte, um café com produtos da culinária caipira (como broa de milho, bolo de fubá etc), um parque de diversões e um palco onde se apresentam artistas regionais. No centro desse espaço há uma praça de alimentação com mesas e cadeiras. Tudo isso conta com uma boa infra-estrutura de estacionamentos, banheiros químicos, seguranças particulares, a presença da Polícia Militar, posto médico com ambulância, saídas de emergência e uma rádio especialmente montada no local na ocasião da festa, a "divina rádio".

\section{A CIDADE: MOGI DAS CRUZES}

Mogi é uma alteração de Boigy que, por sua vez, vem de M’Boigy, que significa rio das cobras, denominação que os índios ${ }^{4}$ davam a um trecho do rio Tietê. Quando a vila foi criada em 1611, devido ao costume de adotar o nome do padroeiro, passou a ser denominada Sant'Anna de Mogy Mirim.

\footnotetext{
${ }^{3}$ Mostra de arte "Denerjânio Tavares de Lyra - A Festa do Divino através da arte". Exposição organizada pela Coordenadoria Municipal de Cultura de Mogi das Cruzes.

${ }^{4}$ Esses índios são chamados, nos livros de história de Mogi das Cruzes, de Guaianazes. Segundo John Monteiro (1994), os índios Guainá eram um povo jê que habitava a região de São Paulo e convivia com os Tupiniquim, de língua tupi, que juntos se enquadravam no esquema dicotômico Tupi-Tapuia (povos que foram aniquilados nos primeiros anos de aldeamentos ou então se diluíram numa população cabocla). O que se sabe realmente é que muitos dos nomes de cidades e lugares de São Paulo vêm do Nheengatu que era uma língua falada em tupi, regulada pela gramática portuguesa e disseminada pelo trabalho missionário entre os séculos XVI e XVIII.
} 
Mogi das Cruzes é o 2o maior município, em área, da Região Metropolitana de São Paulo (RMSP), menor apenas do que a capital. São 721 quilômetros quadrados $\left(\mathrm{km}^{2}\right)$ de extensão territorial. Para se ter uma visão comparativa, a área total da RMSP é de $7.944 \mathrm{~km}^{2}$. A cidade está localizada na região Leste do estado, a 61 quilômetros do centro de São Paulo, portanto, às margens da grande metrópole. Apesar de sua extensa dimensão territorial, grande parte da cidade encontra-se em áreas de proteção ambiental (mais de 65\% do território), como a Mata Atlântica, e áreas de mananciais, como o vale do Alto Tietê e outras importantes bacias hidrográficas que abastecem a RMSP e parte do vale do Paraíba. O município fica justamente no compartimento hidrográfico do Alto Tietê-Cabeceiras, aproximadamente a 50 quilômetros da nascente do rio Tietê, no município paulista de Salesópolis, localizado numa vertente da Serra do Mar. Segundo a última projeção da Fundação Sistema Estadual de Análise e Dados - SEADE, a população de Mogi das Cruzes está em torno de 361.350 pessoas; a RMSP tem uma população de quase 20 milhões de habitantes.

A cidade que nasceu em torno de um aldeamento indígena, hoje se constitui como um pólo econômico importante da região do vale do Alto Tietêt. O setor industrial de Mogi das Cruzes é expressivo, assim como o número de estabelecimentos comerciais, de empresas prestadoras de serviços e do agronegócio, que é considerado referência nacional na produção de hortícola. São quase 100 anos de horticultura na cidade, introduzida pelos imigrantes espanhóis, italianos e, sobretudo, japoneses, a partir da década 1920.

Mogi das Cruzes é uma cidade dividida em oito grandes distritos (Jundiapeba, Braz Cubas, Guatinga, Taiaçupeda, Biritiba-Ussu, Sabaúna, César de Souza e o Distrito Sede, onde se localizam o centro da cidade e os principais bairros). Observando o mapa localizado no sítio da prefeitura na internet, percebese que a mancha urbana da cidade espalha-se ao longo da ferrovia que corta a

\footnotetext{
${ }^{5}$ Região formada por 10 municípios, incluindo Mogi das Cruzes São eles: Aruja, Biritima-Mirim, Ferraz de Vasconcelos, Guararema, Itaquaquecetuba, Poá, Santa Isabel, Suzano e Salesópolis, sendo este último o único que não pertence à RMSP.
} 
cidade a partir de Jundiapeba, passando por Braz Cubas, Distrito Sede, César de Souza e Sabaúna, com uma forte concentração nos três primeiros distritos.

Para além de uma terra de negócio ${ }^{6}$ (na indústria e no comércio), Mogi da Cruzes é também uma terra de festa e de religiosidade. Em todos os distritos da cidade há festas em homenagem aos santos padroeiros nas paróquias como a de Santo Alberto, no bairro de Itapeti, ou de Santo Ângelo, em Jundiapeba. Há também festas para o Divino Espírito Santo, como em Taiaçupeda, Biritiba-Ussu, Sabaúna e César de Souza, com seus festeiros, cerimoniais próprios, levantamento de mastros, missas, procissões e distribuição de "afogado", tudo organizado pelas pessoas das comunidades.

Além dessas, há registros de outras festas, sobretudo ligadas à agricultura, como a Festa do Caqui, da Ponkan, do Pêssego, das Flores etc. Nos jornais antigos, encontrados no Arquivo Histórico Municipal, o sucesso da festa do Divino começou a ser divulgado a partir da década de 1960. Há também notícias sobre as festas da colônia japonesa, que se concentra no bairro da Cocuéra.

Ao consultar alguns livros de historiadores locais (Grinberg, s.d.; Campos, s.d.; Filho \& Filho, s.d.) na Biblioteca Municipal de Mogi das Cruzes, encontramos uma ata da Câmara Municipal, datada de 4 de maio de 1613, acerca do Espírito Santo: “E assiñ requereo mais o dito percurador que ho digo que na dita Camana requereo mais que todos os moradores desta dita Villa Se ayunte despois do Espírito Santo pêra renovarẽ aquele caminho real Visto o qual ouverão os ditos osficiais oSeu requerimento eSeasinão aqui y Eu Ant' glz Escricão da câmara que o Escrevi". Esse documento de 1613 é tido como o primeiro registro da festa do Divino Espírito Santo da vila fundada em 1611, que adquiriu o nome de Vylla de Snõra Santa ana em 1612.

Há outros registros encontrados que mostram referências históricas da festa do Divino na cidade, como o exemplar do periódico O Ypiranga de 1899, que cita nominalmente o festeiro daquele ano. Além disso, um historiador apresenta uma

\footnotetext{
${ }^{6}$ Os conceitos “terra de negócio" e “terra de trabalho" são discutidos por José de Souza Martins (1982).
} 
carta do capelão de Jundiaí, datada de 1723 e endereçada ao governador da capitania de São Paulo por ocasião da festa do Divino (Campos, s.d.). Causa estranheza o historiador utilizar a referência de uma outra cidade para falar de Mogi das Cruzes, mas ele justifica dizendo que o importante é que esses e outros registros são encontrados em livros de tombo das igrejas no estado de São Paulo e estão citados em várias publicações de folcloristas como Luís da Câmara Cascudo e Alceu Maynard Araújo, dando conta de que a festa do Divino está presente no interior do estado desde o século XVII como prova de que a devoção ao Espírito Santo existe há mais de trezentos anos.

Em outro registro bem mais recente (e já num outro contexto) encontramos uma lei promulgada em 1985 (lei n. ${ }^{\circ} 2.890$ de 25 de fevereiro) que coloca a festa do Divino no calendário turístico da cidade como uma festividade tradicional de caráter folclórico. No conjunto dessa lei, incluem-se a Festa da Ponkan e do Verde, a Semana da Pátria, o aniversário da cidade, a Semana do Consumidor, a Festa do Pêssego e da Avicultura, o dia de la Hispanidad, o dia da imigração japonesa em Mogi das Cruzes e a Festa das Nações. Nessa mesma seqüência de registros oficiais, há uma avaliação da Comissão Paulista de Folclore, ligada à Secretaria de Estado da Cultura, que reconhece a festa do Divino de Mogi das Cruzes como uma festa que encontrou um equilíbrio "saudável" entre o folclore e a religião.

Citamos acima alguns poucos exemplos da busca obsessiva de historiadores locais pela origem da festa do Divino como marca de autenticidade e originalidade. Idéias reforçadas pelos meios de comunicação da cidade que publicam e divulgam, ano após ano, textos, artigos, fotos, reportagens especiais e até editoriais dogmáticos acerca da festa. Suas imagens são também exploradas pela TV local que transmite boletins a todo instante durante os dias de festa. Tais textos e imagens não se limitam a reportar a festa, mas buscam interpretá-la na chave da chamada teoria do folclore ${ }^{7}$. Não são poucos os lugares em que se fala sobre a festa do Divino Espírito Santo de Mogi das Cruzes como uma "tradição importada" da Europa, mas com

\footnotetext{
${ }^{7}$ As referências mais recorrentes são: Mário de Andrade, Frazer, Herder, os irmãos Grimm, Garret e Sílvio Romero.
} 
características próprias com mais de trezentos anos de história. Discurso reproduzido inclusive em recente trabalho acadêmico em que o autor analisa a festa do Divino de Mogi das Cruzes como uma manifestação folclórica no contexto de uma sociedade de massas (Moraes, 2003).

Portanto, há todo um aparato racional composto por pesquisas históricas, livros, artigos, desenvolvimento de teorias, panfletos, encartes de jornal, livros de orações e de cantos, cartilhas, receitas, entrevistas, narrativas orais, documentários, sítios da internet, entre outros meios, que reforçam o orgulho ufanista de ser original. De modo que esses instrumentos práticos de normatização da festa, divulgados em sua maioria na forma de textos, funcionam como uma espécie de roteiro, um ponto de apoio para que os organizadores evitem extravagâncias e excentricidades e para que haja, sobretudo, um controle daquilo que faz parte e daquilo que não faz parte da festa, daquilo que é lembrado e daquilo que é suprimido, sustentando assim a suposta relação saudável entre folclore e religião mencionada acima.

\section{A FESTA NA CIDADE}

Em Mogi das Cruzes, os devotos do Divino Espírito Santo participam fielmente da festa do Divino durante os onze dias de sua celebração, que em 2006 ocorreu entre os dias 25 de maio a 04 de junho. Os eventos da festa do Divino de Mogi das Cruzes estão, basicamente, divididos em duas partes que ocorrem concomitantemente. Essa divisão é encontrada na "programação oficial" distribuída em folhetos de divulgação da festa fornecidos pelos organizadores. De um lado, está a "programação religiosa" com as alvoradas, as passeatas das bandeiras, as missas da novena, a procissão de Pentecostes, a cerimônia de incineração dos pedidos; de outro lado, está a "programação folclórica" que engloba as figuras dos festeiros e dos capitães do mastro, o império do divino e as dezenas de subimpérios, a 
quermesse, os folguedos infantis, a entrada dos palmitos, a distribuição do "afogado", o levantamento do mastro, o tapete ornamental, a folia do divino (chamada de "os violeiros") e os grupos de congada e de moçambique (as chamadas “atrações folclóricas"). Enfim, quase tudo que compõe a festa, segundo a igreja católica e os organizadores, está do lado "folclórico".

A separação entre religioso e folclórico encontrada na "programação oficial" está presente na maioria das festas do Divino no Brasil desde o século XVIII, como aponta Carlos Rodrigues Brandão (1978). Para o autor, é possível entender a festa “como um acontecimento coletivo que oscila entre as fronteiras do religioso e as do folclórico, trabalhando, quase sempre, em um território na verdade comum e pouco diferenciado, em que se mistura o que veio da igreja com o que foi trazido pelo povo" (p.49). Além disso, ao longo dos anos, elementos tidos como tradicionais são abandonados e outros são incorporados ou variam de ano a ano. Em Mogi das Cruzes não é diferente. Mas a questão aqui é pensar quem diz o que é religioso e o que é folclórico, quem constrói essa divisão, como isso é sustentado - trata-se de pensar nos agentes que definem o que está dentro e o que está fora. Para se ter uma idéia de como esse corte opera em Mogi das Cruzes, numa das capas de um livro sobre a origem da festa estão dispostas duas fotos, a primeira traz, na parte superior, o andor do Divino Espírito Santo exibido durante a procissão de Pentecostes e a outra, na parte inferior, um carro de boi da entrada dos palmitos.

Essa cisão entre folclore e religião opera na ordem do sagrado e do profano. Entretanto, nem mesmo Durkheim considerou essas categorias como distintas de fato. Para ele, ao sagrado caberia tudo aquilo que é cercado de interditos e tabus, que é objeto da fé (mitos e dogmas), que é contagiante, sublime, digno, poderoso e que envolve uma natureza supra-empírica. O sagrado também seria alvo de rituais (a maneira como o homem prostra-se diante de seu deus) e se caracterizaria como um fenômeno que envolve os fatos da tradição e da consciência coletiva (a moral). O homem designaria objetos e outros homens como sagrados. Uma pedra, por exemplo, pode ser mística e possuidora de poderes especiais não por sua dureza e 
coloração, mas porque o homem assim a considera. A mesma coisa com animais (totens) ou santos. As coisas sagradas se definiriam em relação às coisas profanas na medida em que "são aquelas que os interditos protegem e isolam; as coisas profanas, [são] aquelas às quais esses interditos se aplicam e que devem permanecer à distância das primeiras" (1989, p. 72). Poderíamos classificar de profanas as formas de conhecimento empírico, as técnicas (modos práticos de atuar no ambiente), a natureza empírica (o "real"), aquilo que é cotidiano e trivial, de caráter facultativo, que diz respeito à consciência individual, que é provisório, mutável e livre de interdições. A religião estaria conectada ao sagrado por ser um sistema coletivo de crença em coisas sagradas. Enfim, a religião seria a sacralização da sociedade, ou seja, todas as características encontradas na religião seriam vistas também na própria vida social, assim como o folclórico no religioso e vice-versa.

Portanto, trata-se de um corte meramente formal pois os elementos que compõem a festa estão entrelaçados num feixe de acontecimentos e não estão separados em categorias opostas e distintas. Pensar na idéia de um feixe entrelaçado é importante porque demonstra como as coisas estão juntas, tanto do ponto de vista dos elementos concretos da festa, como dos processos abstratos de elaboração e expressão da devoção. A etnografia da festa do Divino de Mogi das Cruzes que propomos busca justamente acompanhar esse movimento, descrever e analisar o seu funcionamento, seus corpos, seus gestos, práticas e expressões. Sendo assim, segue abaixo uma descrição da chamada "programação religiosa" e da “programação folclórica" encontrada num panfleto de divulgação da festa, além da descrição de outros elementos que fazem parte da festa.

Os devotos ${ }^{8}$ do Divino Espírito Santo, sempre com suas bandeiras nas mãos, são, em sua maioria, católicos que moram na cidade de Mogi das Cruzes. A bandeira é o símbolo sagrado que representa o Espírito Santo para os devotos. De cor vermelha e com um desenho de pomba branca no centro, traz desenhos do Divino sobre raios, geralmente em número de sete, que simbolizam os dons do

\footnotetext{
8 Pensa-se a figura do devoto na perspectiva de Geertz em que “... ser devoto não é estar praticando algum ato de devoção, mas ser capaz de praticá-lo" (1978, p.110).
} 
Espírito Santo. Espalhados ao redor do centro e nos cantos, são dispostas flores de diversos tipos e cores, ou mesmo rostos de anjos. Os mastros das bandeiras ostentam em seus topos uma imagem do Divino pousado sobre uma esfera armilar (o equivalente celeste do globo terrestre), que é esculpida em madeira, metal ou gesso. Interessante observar que, no mastro dos festeiros, o Divino apresenta-se sem ornatos, enquanto no dos devotos ele é todo enfeitado com flores em arcos. Na base são atadas fitas coloridas de tamanhos diferentes, como ex-votos de graças recebidas. Há o costume, também, de os devotos darem nós nas fitas a cada pedido feito. A pomba branca como representação sensível do Divino Espírito Santo está por toda parte da festa e aparece em algumas passagens da bíblia, em especial, no batismo de Jesus Cristo: “Depois de ser batizado, Jesus logo saiu da água. Então o céu se abriu, e Jesus viu o Espírito Santo, descendo como pomba e pousando sobre ele" (Mateus: 3, 16). Em outra passagem, encontramos uma descrição muito parecida: “Todo o povo foi batizado. Jesus, depois de batizado, estava rezando. Então o céu se abriu, e o Espírito desceu sobre ele em forma corpórea, como pomba. E do céu veio uma voz: Tu és o meu Filho amado! Em ti encontro o meu agrado" (Lucas: 3, 21-22).

Os dons do Espírito Santo são favores e características espirituais de ordem sobrenatural que atingem a vida do ser humano que se entrega a Deus, que se une teologicamente com Deus. São sete os dons que aparecem na festa do Divino de Mogi das Cruzes e estão divididos, segundo um sacerdote da cidade, em dois grupos. No primeiro grupo, estão os dons da sabedoria, do entendimento e da ciência: esses dons procuram conteúdos e verdades e estariam ligados à inteligência, enquanto que os do segundo grupo, os do conselho, da fortaleza, da piedade, e do temor a Deus estariam ligados à vontade, à uma vida em santidade.

Esses sete dons do Espírito Santo têm, em Mogi das Cruzes, sua cor característica: o dom da sabedoria é de cor azul; o do entendimento, prata; o da ciência, amarelo; o do conselho, verde; o da fortaleza, vermelho; o da piedade, azulmarinho; e o do temor a Deus, roxo. Não se sabe exatamente a origem desses dons 
na festa do Divino, tampouco a associação entre o dom e a cor. Na bíblia, encontramos algumas referências aos dons, mas não aos sete dons como aparecem em Mogi das Cruzes e nem sua relação com as cores. Aliás, na liturgia aparecem inúmeros dons que não estão associados a nenhuma cor. As cores que aparecem na liturgia dizem respeito a outros fatos, sobretudo, ligados à época da quaresma e da Semana Santa. Evidentemente, o vermelho e o branco têm uma grande força simbólica no catolicismo no que diz respeito à pomba, à pureza de Nossa Senhora e ao fogo do Espírito Santo.

Ainda sobre a relação entre os dons e as cores na festa do Divino de Mogi das Cruzes, há um depoimento de um bispo da década de 1980, colhido num livro sobre as origens da festa, tentando explicar os equivalentes cromáticos dos dons. Segundo o bispo, o dom da sabedoria é de cor azul porque a verdadeira sabedoria vem do céu. O dom do entendimento, de cor prata, diz que a compreensão do sentido da vida do homem deve ser clara como a prata. $\mathrm{O}$ dom da ciência, de cor amarela, representa o ouro que conduz ao ato da fé. O dom do conselho, de cor verde, está ligado à esperança, ou seja, quem dá e recebe bons conselhos alimenta esperanças. O dom da piedade, de cor azul-marinho, está associado aos perigos do mar, pois a piedade associa-se à oração, daí para vencer as tempestades do mar é preciso usar a força da oração. O dom da fortaleza, de cor vermelha, está associado ao sangue dos mártires e sela o testemunho dos que são movidos pelo Espírito Santo. O dom do temor a Deus, de cor roxa, diz que o homem, que com verdadeira fé confia e crê na misericórdia de Deus, não abusa da justiça divina.

Poderíamos dizer que a associação entre os dons e as cores é, aparentemente, arbitrária. Evocando a figura de Marcel Mauss, diríamos que se trata de um esquema classificatório. Para Mauss, “toda classificação implica uma ordem hierárquica da qual nem o mundo sensível nem nossa consciência nos oferecem o modelo" (2001, p.403).

Marshall Sahlins diz que o ser humano não vive sem significar o mundo. $\mathrm{O}$ imperativo da ordem opera como um mecanismo classificador na medida em que as 
coisas ganham significado na posição em que ocupam em relação às outras coisas. As culturas têm suas gramáticas e suas lógicas próprias. Em Cultura e razão prática (1979), o autor discute a sociedade ocidental como uma cultura que tem suas estruturas simbólicas de significação. Sahlins se interessa particularmente pelas cores, tanto no vestuário norte-americano como no sinal de trânsito em que descarta a aparente arbitrariedade na seleção das cores e desnaturaliza o vermelho como um símbolo universal de perigo (que em outros momentos pode representar força, virilidade, fertilidade, sexualidade etc).

Em outro texto em que fala sobre as cores, Sahlins (2004) diz que os seres humanos dispõem de uma percepção cromática limitada. Para ele, "essas estruturas perceptuais são desprovidas de significado, são meras combinatórias formais de oposição e correlação. Como tais, são apenas a matéria-prima da produção cultural, mantendo-se latentemente disponíveis e incompletamente realizadas até que um conteúdo significativo seja atribuído aos elementos do conjunto cultural. Assim, ao se objetivar num sistema de cor, um grupo humano realiza o ato cultural essencial de criar uma ordem conceitual a partir de uma ordem natural. Mas esse código deve ser socialmente acessível: o sucesso do projeto cultural depende da apropriação coletiva dos traços e relações objetivas que geralmente se fazem presentes para os sentidos" (2004, pp.173-174, grifo do autor). Em suma, o conteúdo e o significado da cor emana da cultura e não da cor em si mesma e toda escolha implica numa ordem classificatória segundo relações muito especiais de cada cultura.

O festeiro é a pessoa responsável pela organização da festa - uma espécie de mecenas religioso. Ele faz um investimento pessoal na festa (como um dever em forma de atuação) e recebe bens simbólicos em troca (como um direito em forma de prestígio). É o festeiro quem paga e assina o cheque das despesas, mas também recebe homenagens: carrega consigo a coroa e o cetro e substitui a tradicional figura do imperador do divino. Para Mário de Andrade, "O Imperador não é apenas o homem que organiza e paga os festejos semi-religiosos do seu culto do Divino: é principalmente, pro povo, o homem do qual todos comem e bebem, às vezes por 
vários dias" (1937, p.63). Segundo Luís da Câmara Cascudo, o prestígio do imperador do divino era tão grande que o "título de imperador do Brasil foi escolhido, em 1822, pelo ministro José Bonifácio de Andrada e Silva, porque o povo estava mais habituado com o nome de Imperador (do Divino) do que com o nome de Rei" (2000, p.199). Para a historiadora Martha Abreu (1999), a afirmação de Câmara Cascudo tem uma dose de exagero e de ironia, mas ressalta a interessante (e estreita) relação entre o mundo da política e o da religião. De qualquer maneira, nos dias de festa do Divino em Mogi das Cruzes, o festeiro tem status de aristocrata: ocupa lugar de destaque ao lado do prefeito e do bispo nos principais cerimoniais, e também na entrada dos palmitos e na procissão de Pentecostes.

No entardecer do sábado que antecede o dia de Pentecostes, há um cerimonial para o cortejo de levantamento do mastro. O capitão do mastro (auxiliar direto do festeiro) tem a responsabilidade de conduzir o mastro e posiciona-se em destaque à frente, acompanhado pela esposa e pelo casal de festeiros, carregando a bandeira que será colocada na ponta do mastro, seguido pelos ex-festeiros e devotos. Assim que o cortejo chega à catedral, normalmente às $17 \mathrm{~h}$, ao pé do mastro, seguindo a tradição de Mogi das Cruzes, é servido aos devotos um tipo de licor chamado rosa-sol9 ${ }^{9}$, que deve ser bebido após um pedido feito ao Divino Espírito Santo. O momento de levantamento do mastro representa a abertura simbólica da festa, pois o dia da festa do Divino seria apenas o domingo de Pentecostes e não os onze dias como ocorre atualmente.

As alvoradas são cortejos que saem em procissão pelas ruas do centro de Mogi das Cruzes às 5h da manhã. $\mathrm{O}$ percurso inicia-se com a abertura do império do divino pelo festeiro e o capitão do mastro, juntamente com a folia do divino. Os percursos das alvoradas são afixados na parede do império e são representados através de um mapa projetado pela Secretaria Municipal de Transporte, assinado por um engenheiro da Divisão de Engenharia de Tráfego, discutido e liberado meses antes da festa. Antigamente não se falava em alvorada, era uma procissão ${ }^{9}$ Bebida de baixo teor alcoólico feita a partir de uma calda de açúcar, cachaça, cravo da Índia, canela, semente de
erva doce, noz moscada e casca de limão. Adiciona-se anilina para que a bebida adquira uma cor avermelhada. 
conhecida como "folia" que caminhava grandes distâncias de madrugada, mas no final da década de 1970 um sacerdote exigiu que se mudasse o nome de folia para alvorada. Atualmente percorre-se somente as ruas do centro. No final de cada alvorada é oferecido o "café do divino" no salão paroquial da catedral.

A novena do Divino Espírito Santo consiste em nove missas celebradas às 19h na catedral de Santana. A primeira missa ocorre na sexta-feira, um dia após a abertura oficial da festa e a última no sábado anterior ao domingo de Pentecostes, que encerra a festa. Ao final de cada missa da novena, os devotos, com suas bandeiras e acompanhados pela folia do divino, realizam a passeata das bandeiras, partindo da catedral de Santana. Esse cortejo, cujo formato é parecido com a alvorada, percorre novamente as ruas do centro durante a noite. Porém, desta vez, o objetivo é visitar as casas dos devotos, sobretudo os mais idosos e enfermos, além de locais escolhidos pelos festeiros e organizadores. Os devotos recebem a visita da folia do divino em casa e oferecem comida e bebidas para todos. O núcleo central das passeatas seria visitar as casas das pessoas impossibilitadas de ir às missas, alvoradas etc., mas a maioria das casas visitadas é de pessoas que poderiam perfeitamente acompanhar a festa. A lista das casas é elaborada pelos coordenadores leigos da parte religiosa. De modo geral, são visitadas as casas de exfesteiros que moram perto da catedral.

Chama a atenção, no folheto da programação oficial, um evento aparentemente isolado, que ocorre no primeiro sábado à tarde, chamado de Culto Ecumênico pela Unidade dos Cristãos, com representantes de igrejas cristãs. Poderíamos pensar que se tratava da mais alta expressão do Espírito Santo, dado que todas as igrejas cristãs, de certa forma, partilham da doutrina do Espírito Santo, na unidade de um Deus Pai. Na liturgia, o Espírito Santo está ligado à comunicação, à capacidade de falar e entender em outras línguas: “E cada um de nós em sua própria língua os ouve anunciar as maravilhas de Deus!" (At: 2, 11). Porém, surpreendentemente, o culto ecumênico, no lugar de ter representantes da maioria das igrejas cristãs, tinha apenas um da igreja metodista e um da igreja luterana. Para 
a igreja de Mogi das Cruzes, os "outros cristãos" são os metodistas e os luteranos, aliás, estes últimos nem possuem templos na cidade.

O império do divino, como foi dito anteriormente, é uma capela montada no centro da cidade em frente à catedral de Santana. Antigamente era montado na casa do festeiro ou em alguma casa ao redor da catedral. De uns dez anos para cá, tem sido montado numa tenda especialmente construída para este fim na praça em frente à catedral, na praça Coronel Almeida. No império, é realizada a oração da coroa do Espírito Santo durante o dia todo. Além disso, é de lá que parte o cortejo da alvorada. Os subimpérios são altares montados pelos devotos em locais mais afastados do centro. O número de subimpérios cresceu nos últimos anos e têm sido montados inclusive nas escolas. A inauguração de um subimpério é uma festa em particular, e conta com a presença dos festeiros, ex-festeiros e membros da comunidade do bairro.

A quermesse ocorre durante dez noites num espaço amplo cedido pela prefeitura. O espaço é um pouco distante do centro da cidade, tem estacionamento e atende diariamente cerca de 40 mil pessoas. Nela, é vendido o "afogado", um prato típico da festa do Divino em Mogi das Cruzes, que consiste basicamente em um cozido de carne e alguns legumes. É tradição distribuí-lo, gratuitamente, ao final da entrada dos palmitos.

Os folguedos infantis ocorrem no terceiro dia de festa, num domingo, no mesmo espaço onde é feita a quermesse e contam com a participação de crianças das escolas da cidade. São realizadas antigas brincadeiras de criança como quebra potes, corrida de saco, corrida do ovo na colher, cabra-cega, cabo de guerra, entre outras.

A entrada dos palmitos é realizada no penúltimo dia da festa e constitui, segundo o folheto de divulgação, o auge dos rituais da festa porque representa a chegada da população rural à cidade trazendo os palmitos da Mata Atlântica para participar do dia de Pentecostes. Em relação a outras festas no país, a entrada dos palmitos é uma peculiaridade da festa do Divino de Mogi das Cruzes. As pessoas contam que o Espírito Santo abençoava a casa onde era colocada a palmeira. Após a 
festa, os palmitos eram distribuídos entre os devotos. Hoje - apesar de não se cortar mais o palmito - esse ritual é o mais esperado pela população que assiste ao cortejo ao longo das ruas da cidade.

O tom festivo, para não dizer carnavalesco, da entrada dos palmitos é marcado pela participação dos grupos de congada e de moçambique. O desfile desses grupos é uma espécie de bailado dramático, com danças coreografadas, muita cor, música e alegria, configurando um verdadeiro teatro de rua na cidade.

O tapete ornamental é feito em ocasião da procissão de Pentecostes realizada no último dia da festa. Cinqüenta por cento do material utilizado no tapete é doado pela Associação Pró-Festa do Divino Espírito Santo e os outros cinqüenta pelas escolas. O trabalho de preparação envolve entre 700 e 800 pessoas. O tapete é montado a partir de quadros intercalados por uma "passadeira" cujo desenho é padronizado e projetado por um artista plástico da cidade. Os quadros são desenhados pelos alunos com temas representando a festa, ou seja, a bandeira, o lema do ano (no caso de 2005, família, fé e caridade; em 2006, Família: construtora da fraternidade e paz), os sete dons do Divino Espírito Santo, o folclore da cidade e outros temas geralmente ligados à bíblia e à campanha da fraternidade da igreja católica. Os principais materiais usados são: serragem, areia, tingimento para colorir a areia e a serragem, quartzo em pó, terra, pó de café, além de outros materiais como papelão, tampinhas de garrafa, plástico etc. Há um cuidado para não se usar pedras, nem galhos de árvores para evitar acidentes.

O tapete ornamental é uma tradição inventada há pouco mais de dez anos e é executado pelos alunos e professores das escolas da cidade. Não se sabe exatamente como e por que esse tapete foi criado, dizem que foi idéia de um artista plástico da cidade. Enfim, tradicional nas celebrações de Corpus Christi, foi introduzido na festa do Divino de Mogi das Cruzes em 1994. O tapete encerra o caminho que conduz o bispo até a catedral de Santana ao final do percurso da procissão de Pentecostes. Passado o cortejo, uma empresa de limpeza contratada 
pela prefeitura é responsável pelo recolhimento do material que, ao final, fica completamente retorcido e desfigurado.

O ponto alto da devoção na festa do Divino de Mogi das Cruzes é a procissão de Pentecostes realizada no domingo - dia em que se comemora, segundo a liturgia cristã, a descida do Espírito Santo sobre os apóstolos. Na procissão, é dado destaque especial ao andor. Todo enfeitado, ele traz a imagem que representa o Divino Espírito Santo: a pomba.

A incineração dos pedidos ocorre no domingo de Pentecostes como ato de encerramento da festa do Divino. Em frente ao império do divino, acende-se um fogo num grande tambor onde são queimados milhares de pedidos feitos durante a festa e ao longo do ano. Essa cerimônia começou na época em que o bispo que explicou o significado das cores estava à frente da diocese de Mogi das Cruzes. Conta-nos uma das rezadeiras que os pedidos ficavam acumulados e não se sabia o que fazer após a festa. Então o bispo resolveu dar um fim a eles queimando-os. Acredita-se que a fumaça é o contato direto com o Espírito Santo.

A descrição apresentada acima servirá de contextualização para a leitura dos próximos capítulos em que esses elementos serão discutidos e analisados, bem como a relação dos devotos com o Divino Espírito Santo. Antes, porém, voltemo-nos aos lugares de produção da festa, ou seja, aos lugares onde são pensados e elaborados elementos importantes da festa, tendo em mente que as coisas não estão simplesmente divididas entre religiosas e folclóricas, mas assim se apresentam. A questão é entender como e quem processa as coisas dessa maneira e por que faz desse modo e não de outro. 


\section{ASSOCIAÇÃO PRÓ-DIVINO: RELIGIÃO, CULTURA E EMPRESA}

A Associação Pró-Festa do Divino Espírito Santo, também chamada de Associação Pró-Divino, foi criada em 1994 por um grupo de ex-festeiros e ex-capitães do mastro com o intuito de preservar o patrimônio material da festa do Divino, levantar fundos para a realização da festa através de eventos culturais e religiosos, dar suporte ao festeiro e ao capitão do mastro na organização, bem como manter sob controle de um mesmo grupo a hegemonia da festa. Além disso, dizem que a idéia de uma associação como esta seria difundir a devoção ao Divino Espírito Santo, pesquisar e realizar levantamento de dados sobre a festa do Divino com o objetivo de construir num futuro o Museu do Divino na cidade de Mogi das Cruzes. Mas percebemos que a relação entre a Associação Pró-Divino e a festa do Divino está para além dos assuntos que envolvem a devoção ao Divino Espírito Santo. Vejamos.

O principal papel desta associação, na nossa acepção, está na sistematização e na moralização das práticas e representações religiosas, no sentido de Pierre Bourdieu (1999) ao falar da religião como uma empresa que detém o monopólio dos bens de salvação. Mas a religião não opera numa estrutura una, necessita de diferentes instâncias religiosas, de um corpo de especialistas e de instituições responsáveis pela gestão desses bens e pelo exercício legítimo do poder religioso cujo objetivo é inculcar nos devotos (consumidores) um habitus religioso que garanta um ajuste a uma visão política do mundo social.

A Associação Pró-Divino não seria necessariamente uma empresa de bens de salvação. Ela funciona como uma espécie de administradora de bens religiosos, ou seja, expande de maneira organizada a produção e a difusão desses bens. A igreja, detentora do monopólio do "capital religioso", não a vê como uma concorrente, mas como uma auxiliar legítima do serviço religioso, uma gestora desse capital. Nas palavras de Bourdieu compreendemos melhor esta relação: “o capital de autoridade propriamente religiosa de que dispõe uma instância religiosa depende da força 
material e simbólica dos grupos ou classes que ela pode mobilizar oferecendo-lhes bens e serviços capazes de satisfazer seus interesses religiosos, sendo que a natureza destes bens e serviços depende, por sua vez, do capital de autoridade religiosa de que dispõe levando-se em conta a mediação operada pela posição da instância produtora na estrutura do campo religioso" (1999, p.58).

Mas a Associação Pró-Divino não pode negociar religião; então, ela negocia cultura, ou melhor, negocia e administra "folclore". A associação tem o controle leigo da festa, ao passo que a igreja detém o controle religioso. Sem poder se organizar como uma instituição religiosa, a associação foi declarada de utilidade pública por meio da lei municipal n. ${ }^{\circ} 4.828$ de 29 de outubro de 1998, de acordo com o projeto de lei n.․ㅡ 285/98, de autoria do vereador José Antônio Cuco Pereira, que foi festeiro no ano de 2003. Atualmente, a associação está estruturada da seguinte maneira: uma diretoria executiva dividida entre presidente, vice-presidente, primeiro e segundo secretários, primeiro e segundo tesoureiros; diretoria de assuntos religiosos; diretoria de assuntos culturais e folclóricos; diretoria de patrimônio, vice-diretoria de patrimônio; e diretoria de assuntos sociais. Além disso, possui um conselho fiscal e um conselho consultivo com membros efetivos e suplentes. Em todos esses cargos estão situadas pessoas que foram, em algum momento, festeiros ou capitães do mastro. Além disso, há pessoas ligadas aos serviços das pastorais da igreja católica, aos grupos de pequenos empresários e comerciantes, aos grupos de assistência social e aos políticos da cidade. A estrutura que distribui os instrumentos de produção da festa está de acordo com a "competência" e a "qualificação" de cada pessoa.

O organograma de funcionamento da festa do Divino em Mogi das Cruzes tem características empresariais com delimitações explícitas das áreas de competência, com funções, nomeações e regras organizadas da seguinte maneira:

No topo da hierarquia está a diocese, na figura do bispo, que nomeia o festeiro e delega a este o dever de organizar a festa, que, por sua vez, chama um auxiliar, que é capitão do mastro. Mas alguns festeiros - quase sempre - não têm 
experiência para organizar a festa. Então, em paralelo, entra o trabalho da Associação Pró-Festa do Divino Espírito Santo, que não interfere na autoridade do festeiro, mas o auxilia e o apóia, mantendo o patrimônio material durante o ano todo e colocando-o a serviço da festa.

Através da Associação Pró-Divino, em conjunto com o festeiro, são delineadas algumas coordenadorias cuja função é dar suporte à festa. São elas: religiosa, folclórica, casa da festa, quermesse, ornamento e marketing. Há sempre vários coordenadores e subcoodernadores em cada um desses lugares. Na casa da festa, por exemplo, um casal de ex-festeiros coordena os trabalhos. A quermesse tem quatro coordenadores e cada barraca tem seus próprios coordenadores. Nos assuntos religiosos, há uma pessoa que coordena o trabalho das rezadeiras, as alvoradas, as novenas (articulado com as paróquias), as procissões, as passeatas com a folia do divino e também decide os trajetos a serem percorridos. A coordenadoria de ornamento cuida da produção do império e da procissão de Pentecostes. A coordenadoria de folclore cuida fundamentalmente da entrada dos palmitos. Em suma, todas essas coordenações dão assessoria à pessoa que estiver no papel de festeiro naquele momento.

Todas essas instâncias têm suas despesas. Desse modo, os coordenadores elaboram um orçamento e o levam para o festeiro, que avalia e libera a verba. $\mathrm{O}$ festeiro abre uma conta no Banco do Brasil em nome da Mitra Diocesana e busca, juntamente com a coordenadoria de marketing, recursos com os patrocinadores, que recebem espaço de publicidade nos cartazes espalhados pela cidade e na quermesse durante os onze dias. Para se ter uma idéia, os patrocinadores de um determinado ano foram: a GM, que doou um carro zero quilômetro; o D'Avó Hiper, que doou vinte mil reais em produtos alimentícios; a Brahma, os equipamentos (máquinas) e cadeiras da praça de alimentação; o Papel Suzano, os panfletos. Além deles, o Habib's, o Banco do Brasil, a Oscar Calçados, Itaipu Shopping Construção e a Universidade Mogi das Cruzes fizeram doações em dinheiro. É preciso explicar um pouco esse fluxo de recursos. O valor doado pelo supermercado foi em produtos ao 
preço do consumidor, ou seja, o festeiro comprou no supermercado uma quantia alta de produtos e recebeu em troca um desconto, no valor mencionado, que corresponde a $20 \%$ do valor gasto. Os materiais utilizados na logística vieram da loja de material construção, mas nem tudo, pois uma parte foi comprada. E assim com os outros patrocinadores e colaboradores.

A prefeitura entra com toda a logística da quermesse e da entrada dos palmitos, através da Secretaria de Serviços Urbanos. Há toda uma estrutura operacional que sustenta a festa. Para a entrada dos palmitos, por exemplo, buscamse nas cidades vizinhas os animais e os carros de boi usados no desfile, sobretudo nas cidades de Salesópolis, Guararema e Santa Isabel. Os bois vêm em caminhões, em gaiolas, e ficam um dia inteiro descansando num lugar reservado na entrada da cidade.

Enfim, boa parte das despesas é coberta pela receita da quermesse e dos patrocínios, mas, se no final disso tudo houver prejuízo, o festeiro não pagará do próprio bolso, haverá arrecadações durante o ano todo para cobrir eventuais débitos.

Sob uma aparente razão utilitarista, os patrocinadores que colaboram na festa não recebem somente espaço de publicidade nos cartazes espalhados pela cidade. Ocultado nesse gesto está a dádiva que serve para estabelecer relações cujo retorno pode não ser imediato, porém sempre há a contra-dádiva (um presente dado espera sempre um presente em retorno). Mauss, no Ensaio sobre a dádiva (1974), discute, através de diversos exemplos etnográficos, o caráter universal da dádiva. Para ele, o caráter voluntário das prestações ofertadas generosamente é cercado de interesses morais e econômicos. Para Godbout (1999), não se trata apenas da universal necessidade de dar e receber através de um cálculo mercantil ou do poder do estado porque as pessoas não trocam apenas mercadorias, mas trocam palavras, frases e discursos. Ou seja, não somente bens materiais são trocados, mas bens simbólicos. De modo que outras formas de bens e outras relações são estabelecidas. Ademais, na palavra de Mauss, "o que trocam não são exclusivamente bens e 
riquezas, móveis e imóveis, coisas economicamente úteis. Trata-se, antes de tudo, de gentilezas, banquetes, ritos, serviços militares, mulheres, crianças, danças, festas, feiras em que o mercado é apenas um dos momentos e onde a circulação de riquezas constitui apenas um termo de um contrato muito mais geral e muito mais permanente" (1974, p.45).

Não temos notícias sobre eventuais prejuízos financeiros da festa, pelo contrário, nos últimos anos a festa tem dado muitos $\operatorname{lucros}^{10}$. Ao final da festa, o festeiro é obrigado a prestar contas para o bispo sobre o que foi arrecadado e entregar boa parte do dinheiro para a diocese; apenas uma pequena parte é destinada à Associação Pró-Divino (cerca de 5\% dos lucros). Aparentemente não há conflito na relação entre a igreja e a associação, mas as coisas não se dão dessa maneira, essa relação é tensa em alguns momentos. Como a igreja tem o monopólio do sagrado e a associação não pode vender religião - apenas administrar -, todo lucro desse capital fica na conta da diocese de Mogi das Cruzes, que decide sobre os destinos do dinheiro e repassa uma pequena quantia para a associação.

Segundo o depoimento de um ex-festeiro, colhido numa entrevista publicada num jornal da cidade, há um jogo de intrigas e uma luta pelo poder na festa do Divino. A manchete da entrevista dizia: "Estão brincando com o divino". Para o exfesteiro, um dos fundadores da Associação Pró-Divino, a igreja, na figura do bispo, acha que é "dona" da festa do Divino. Para ele, o futuro da festa está ameaçado por conta do que ele chama de "guerra pelo poder". O problema começou quando a associação, após dez anos indicando o festeiro, não pôde fazê-lo num determinado ano, cabendo exclusivamente ao bispo o poder da escolha. (Aliás, até 1979 não havia escolha de festeiro por nenhuma das partes, e sim a realização de um sorteio.) $\mathrm{O}$ exfesteiro fala em nome de uma "comunidade dos devotos" e lamenta: "Não podemos perder tudo o que conquistamos". Ou seja, a hegemonia no controle da festa e a autonomia no uso dos recursos estão ameaçadas, pois com a indicação de um festeiro pelo bispo essa seqüência interrompeu-se e toda a renda da festa foi

${ }^{10}$ Em 2005, a Festa do Divino arrecadou mais de 350 mil reais conforme anunciou o festeiro. 
repassada para a diocese, causando muito desconforto na associação. "Entre todos os que participam da festa fica um clima chato. $\mathrm{O}$ festeiro é obrigado a prestar conta de tudo o que foi arrecadado, o bispo não", desabafa o ex-festeiro.

Há uma rede de articulações entre as instituições para a realização da festa nos moldes apresentados acima. Há um envolvimento com a Prefeitura Municipal, o serviço de limpeza urbana, a Defesa Civil, a Guarda Civil Municipal, a Polícia Militar, o Tiro de Guerra, a Associação Pró-Divino e os festeiros para preparar os deslocamentos de estruturas logísticas que envolvem a festa, garantir a segurança das pessoas e assegurar o controle da cidade.

Além disso, a festa tem uma assessoria de imprensa. Segundo um dos membros da associação, isso é necessário para evitar notícias nos jornais do tipo: “O trânsito de Mogi ficou um caos". Sobre a participação da mídia, percebe-se que a expansão da festa se deu com a entrada da TV Diário e de links ao vivo para todo o estado de São Paulo como aconteceu certo dia no telejornal Bom Dia, São Paulo da Rede Globo.

Para os organizadores, do ponto de vista religioso, a festa está muito bem organizada. Mas na parte folclórica, é preciso ter um cuidado e um preparo especiais para que as coisas não caiam no esquecimento e para que exageros não sejam cometidos. Em suma, a festa do Divino de Mogi das Cruzes é organizada fundamentalmente por uma agência legalmente instituída com estatuto formal e legitimidade para controlar o que faz e o que não faz parte da tradição da cidade. Nessas relações, por vezes conflituosas, são gestados os discursos que produzem a festa.

A CASA DA FESTA

A casa da festa é a sede da Associação Pró-Festa do Divino Espírito Santo. Na casa da festa trabalham entre 60 e 70 voluntárias, também chamadas de "abelhinhas do 
divino", que são responsáveis pela produção dos doces e salgados vendidos na barraca da associação durante a quermesse, que também conta com um bom número de voluntários, cerca de 50 (algumas pessoas chegam a receber uma pequena ajuda em dinheiro). Antes de chegar na sede, que fica nos fundos de um terreno cedido pela prefeitura, passa-se por dois barracões onde são guardados materiais que sobraram de festas anteriores. A casa da festa é um grande salão com uma porta de entrada na frente. Lá dentro têm duas fileiras de mesas onde as "abelhinhas do divino" trabalham. No fundo ficam os fogões a gás e as mesas onde são feitos os salgados. Do lado esquerdo, ao lado dos freezers, tem um depósito, um subimpério e duas salas onde funcionam o almoxarifado e a secretaria. Do lado direito, no alto, estão fotos gigantes sobre os personagens da festa e cartazes de festas anteriores desde 1993. Dentro da secretaria há mais cartazes de festas anteriores, inclusive da festa do Divino de Alcântara, no Maranhão, e do Revelando São Paulo, realizado no Parque da Água Branca.

A denominação "casa da festa" aparece no penúltimo parágrafo do texto de Mário de Andrade publicado em 1937, em que ele discute a entrada dos palmitos e, conseqüentemente, a festa do Divino de Mogi das Cruzes. A descrição de Mário de Andrade é reveladora: “Na festança Mogiana: no dia 29 houve distribuição de carne fresca e de donativo aos pobres no açougue do Quinzinho; no dia 30 distribuição de doces aos presos da cadêia e aos doentes da Santa Casa; e finalmente no dia seguinte, fim de festa, houve distribuição de churrasco e refogado ao povo quasi o dia todo, distribuição de guloseimas á crilada do cinema, e pela noite adiante, na 'casa da festa', distribuiu-se comes e bebes a quem queria em quantidade espantosa" (1937, p.64).

Conversamos com o casal que coordena os trabalhos na casa da festa desde 1994, um ano após terem sido festeiros. Eles disseram como funciona a arrecadação dos produtos usados na produção dos doces e salgados vendidos na quermesse. A principal fonte de arrecadação são as escolas públicas e privadas. Os primeiros contatos são feitos com a prefeitura, através da Secretaria Municipal de Educação, e 
com a Diretoria de Ensino do Estado, para então fazer os contatos diretamente com as escolas municipais e estaduais. Há também o contato com as escolas particulares. As escolas também participam em outros momentos da festa, como a entrada dos palmitos, a produção de subimpérios nas escolas e, principalmente, a confecção do tapete ornamental etc. A casa da festa solicita aos pais, através de uma lista, a doação dos seguintes itens: lata de óleo, margarina, farinha de mandioca torrada, açúcar, chocolate em pó, farinha de trigo, farinha de milho branca, trigo para quibe, arroz, feijão, sagu, groselha, vinho, leite condensado, leite de coco, leite longa vida de caixinha. Os produtos solicitados são colocados aleatoriamente em quatro listas com seis itens cada. Há uma equipe da própria casa da festa encarregada de distribuir as listas e retornar às escolas para coletar os produtos; isso ocorre geralmente um mês antes do início da festa. Quem contribui recebe uma pequena medalha do divino, conhecida como divininho. Quem não contribui...

Além dessas arrecadações, a casa da festa confecciona os salgados e os doces vendidos na quermesse. Os doces são aqueles mais conhecidos da culinária caipira: doce de abóbora, mamão, cidra, batata-doce e sagu. Todos são preparados em tachos de cobre e no fogão de lenha. Os salgados são aqueles encontrados nos bares da cidade: coxinha de frango, quibe, pastel e bolinho de jabá. Além desses, há um salgado especial, muito consumido e com uma técnica toda própria de preparo: é o tortinho. Mais de mil unidades desse salgado são consumidas por noite na quermesse. Esse salgado é especial em relação aos outros porque é feito de farinha de milho branca e recheado com carne moída. Os tortinhos devem ser feitos e consumidos no mesmo dia; nunca se congela. Tudo é feito na casa da festa durante o dia, transportado em gavetas, também chamadas de tabuleiros, com um pano úmido por cima até a quermesse, onde é fritado e vendido por um real. Perguntados sobre o porquê desse cuidado e zelo, justificam que a massa feita de farinha de milho é extremamente delicada e não suporta o congelamento porque endurece muito facilmente. Em segundo lugar, os responsáveis disseram que, de acordo com a tradição caipira, esse salgado - que tem o gosto próximo ao da polenta - tem de 
ser feito e consumido na hora. Se por acaso sobrar algo na quermesse e não puder ser congelado para o dia seguinte, tudo é doado para instituições de caridade, asilos, creches, hospitais, como a Santa Casa.

O "afogado", principal prato consumido durante a festa, é preparado no local da quermesse por uma equipe designada pela casa da festa e pela Associação Pró-Festa do Divino Espírito Santo. Mas o "afogadão", prato distribuído gratuitamente ao final da entrada dos palmitos, é preparado na casa da festa.

Há uma pessoa responsável pela articulação entre as escolas e a festa do Divino. Essa pessoa inclusive foi diretora de escola pública durante muito tempo até se aposentar e também festeira na década de 1990. Segundo ela, a participação das escolas começou no ano 1993 com apenas três unidades (incluindo a que ela era diretora). Em 1994, passou para seis. Desde então, esse número tem crescido e hoje já são mais de cem escolas com subimpérios; número tão grande que nem os festeiros têm condições de visitá-las. Essas escolas contribuem com a doação de alimentos para a quermesse, flores para a entrada dos palmitos e materiais para a confecção do tapete, que teve seu início justamente no ano de 1994. Segundo ela, não há outro evento igual que possa unir a cidade de Mogi das Cruzes como a festa do Divino Espírito Santo. Além disso, segundo ela, a participação das escolas garante a continuidade da festa, pois o envolvimento entre professores, pais e alunos (crianças) começa na sala de aula e extrapola para as ruas da cidade.

As escolas também participam da entrada dos palmitos decorando os carros de boi com flores e desfilando no cortejo - 24 carros de boi desfilam na entrada dos palmitos. Os carros são trazidos de outras cidades, chegam de madrugada e a partir das seis da manhã começam a ser enfeitados. Há um carro especial que abre o desfile chamado de charola que traz os alimentos no alto, suspensos por uma armação de ferro. No final do cortejo, os alimentos da charola são doados para alguma instituição de caridade. É de responsabilidade das escolas e da associação a montagem da charola e de todos os outros carros de boi, incluindo o transporte para os seus locais de origem. 
Todas essas informações foram obtidas nas conversas que tivemos com as pessoas ligadas à Associação Pró-Divino e à casa da festa, inclusive nas visitas que lá fizemos. Tais pessoas também organizam os folguedos infantis, com a ajuda voluntária de estudantes universitários da cidade.

\section{O TRADICIONAL DISCURSO DA TRADIÇÃO}

Em conversa com os membros da diretoria da Associação Pró-Divino, encontramos alguns elementos desse aparato discursivo produtor da festa. Há pessoas responsáveis pela logística que envolve o funcionamento da quermesse, que negociam com patrocinadores, com a prefeitura, requerem autorizações e alterações no trânsito, cuidam do transporte dos grupos que se apresentam, dos carros de boi e dos animais trazidos para a entrada dos palmitos, articulam com as escolas e com as paróquias, há pessoas leigas que coordenam os trabalhos religiosos, pessoas responsáveis pela chamada ornamentação etc.

A primeira imagem que essas pessoas têm do passado da festa do Divino em Mogi das Cruzes remete ao tempo em que a festa ainda era realizada no largo da igreja matriz, hoje praça da catedral. Colhemos depoimentos nos quais as pessoas falam sobre as mudanças da festa ao longo dos anos e da incorporação de mais um dia para a solenidade de abertura do império do divino, como teste para o funcionamento da quermesse, ao mesmo tempo em que justificam esse acréscimo para relembrar a Ordem do Império do Divino Espírito Santo, fundada pela Rainha Isabel de Portugal. Segundo o coordenador da parte folclórica, toda essa idéia de imperador, coroa, bandeira, cortejo etc, vem da corte do império do divino desde a Europa.

Outra imagem evocada é a figura do bandeireiro que fazia a peregrinação o ano todo em busca de esmolas para a realização da festa, como acontece em 
Pirenópolis (GO). O coordenador nos disse que há uma música de uma dupla caipira sobre a bandeira do divino e o bandeireiro peregrino. Hoje, segundo ele, quem faz esse papel é o festeiro ao trazer patrocínios. Um texto de Melo Morais Filho sobre a festa do Divino no Rio de Janeiro traz em suas primeiras linhas essa mesma imagem da bandeira peregrina evocada pelo diretor da Associação PróDivino: "Por vales e serras, por estradas e povoados, meses antes da festa do Espírito Santo, garridos foliões dispersavam-se em bandos no interior da Província do Rio de Janeiro, angariando esmolas para as festas das capitais dos municípios, que se faziam outrora a rigoroso capricho dos festeiros e segundo os donativos das populações devotas". Na seqüência, Morais Filho lembra da figura do festeiro: "A isso, porém, precedia a eleição das mesas das respectivas irmandades e a escolha dos liberais festeiros, à cuja direção e cargo ficavam a solenidade religiosa e os festejos externos" (1979, p.39).

A Associação Pró-Divino é categórica ao descrever o perfil do festeiro nos dias de hoje. Para eles, o festeiro precisa: 1 . ser católico praticante; 2 . ter um relacionamento na comunidade empresarial; 3 . ter capacidade de articulação e gerenciamento. Após revelar esses quesitos básicos, o diretor da associação lamenta que seja assim, pois gostaria que fosse diferente para que pessoas mais "humildes" pudessem ser festeiros, contando, é claro, com o apoio da Associação Pró-Divino e da igreja. A sensação é de que só é festeiro quem faz parte da elite, quando o importante seria ter o conhecimento da festa e a assessoria da associação. Porém, tem sido lugar-comum a presença de pessoas mais proeminentes na sociedade como festeiro, que é anunciado na missa de Corpus Christi pelo bispo.

Sobre a participação dos grupos de congada e moçambique, predominantemente compostos por negros, o discurso evocado é do sincretismo religioso entre o catolicismo e os ex-escravos - discurso freqüentemente acionado pela elite. Para algumas pessoas, a Associação Pró-Divino é responsável pelo resgate desses grupos, que sempre estiveram presentes na festa, mas que estavam dispersos e esquecidos pela cidade. Para Roger Bastide (1971), o mecanismo do 
sincretismo funciona como um sistema coerente de pensamento cuja existência vem do encontro da experiência mística do negro e da tentativa de controle social por parte dos brancos.

O mapa da entrada dos palmitos é preparado pela associação, mas o modo de funcionamento e de montagem é discutido com a prefeitura e com a PM. Todos os momentos são orquestrados do início ao fim, inclusive a dispersão dos cavaleiros e a distribuição do "afogadão" que é feita em dois lugares diferentes para melhor atender a população. Num determinado local, distribui-se para àqueles que desfilam e num outro, para o público em geral.

A entrada dos palmitos é montada da seguinte maneira: em primeiro lugar vem o que ele chama de grupo de apoio, distribuindo bandeirinhas e água. Depois vem o bandeireiro montado num cavalo e os bonecões da AMDEM (Associação Mogicruzense de Defesa do Menor) representando as figuras da festa como o fogueteiro, as doceiras, os lanterneiros. Em seguida, a banda de música, os festeiros, os devotos, os alunos das escolas e da catequese, além dos grupos folclóricos. No final, os animais. Antigamente os animais vinham na frente, mas por uma "questão estratégica", inverteu-se a ordem para que as pessoas não pisassem nos excrementos dos animais.

Abrindo a parte dos animais vem a charola, que representa a origem da festa do Divino porque desfila pelas ruas da cidade carregada de alimentos que são distribuídos para os pobres. Os palmitos também vêm em carros de boi em pequenas mudas trazidas de um viveiro da Companhia Energética de São Paulo (CESP), em Paraibuna (SP), e que depois são doadas para as crianças plantarem. Em Mogi das Cruzes ainda há palmitos na Mata Atlântica, mas de lá é proibido retirar. Então, retiram-se folhas de palmeiras e as fixam nos postes por onde o desfile passa.

Outra coisa "típica", segundo o diretor da associação, seria a participação de tropeiros e da cavalhada. A idéia de resgatar a cavalhada é que, segundo ele, isso acompanha a festa do Divino desde a Europa. O desejo é fazer uma representação como ocorre em Pirenópolis (GO). E explica: “Eu já trouxe três vezes de Guararema 
$(\mathrm{SP})$ ". "A cavalhada representa a luta entre cristãos e mouros como um teatro a céu aberto com Imperador Mouro, Imperador Cristão, os Castelos e as lutas. História que termina com vitória dos cristãos e conversão dos mouros".

Há duas pessoas responsáveis pela coordenação da parte ornamental da festa. Esta instância produz o império do divino, a procissão de Pentecostes e cuidava, até recentemente, da decoração da catedral de Santana. São eles que escolhem os objetos, os materiais, as texturas, as flores e as cores empregadas tanto no império como na procissão. Os materiais utilizados são parte do patrimônio da Associação Pró-Divino. Os bens duráveis são reutilizados e ficam guardados na casa da festa. O trabalho de criação fica a cargo de uma única pessoa que projeta e executa o andor da procissão, as roupas dos componentes, além da montagem da capela do império do divino.

Para os coordenadores, a disposição das diversas alas da procissão segue uma seqüência lógica. A cada ano novas coisas são introduzidas, ou substituídas, mas nunca são deixados de fora as irmandades, os totens dos dons, onde o bispo faz uma pausa para explicar o seu significado e soltar uma pomba, os festeiros, o andor, a banda Santa Cecília e os símbolos Fé, Esperança e Caridade (representados por uma cruz, uma âncora e um coração). As variações giram em torno de crianças vestidas de imperadores, de rapazes como tocheiros e meninas vestidas de anjos. Enfim, são idéias introduzidas pelos coordenadores e que dependem da verba de patrocínio disponibilizada pelo festeiro para serem aplicadas. Os materiais são geralmente reciclados e ficam guardados na casa da festa, juntamente com as roupas.

Eles, os coordenadores, disseram que tomam cuidado com os tons das cores, buscando uma linha mais sóbria, próxima às cores do Divino Espírito Santo, com atenção especial ao vermelho e o branco, pois a procissão de Pentecostes busca demonstrar a religiosidade. O principal conteúdo da festa é a devoção.

Ao longo dos anos, o andor foi aumentando de tamanho e ficou muito pesado para ser carregado nos ombros dos devotos. Então, desde 2000, passou a ser 
transportado num carro com rodas. $\mathrm{O}$ andor deveria levar a imagem do divino, a pomba, mas é montado com uma estrutura de ferro para carregar as flores, os castiçais com luzes e bateria para iluminação etc. A cada ano é feito um andor novo.

Segundo os coordenadores, a ornamentação é fundamental porque não existe festa sem enfeite, por mais simples que seja. Para eles, muitas pessoas vêm até ao centro de Mogi das Cruzes para ver os enfeites do império, a procissão de Pentecostes e a igreja (quando era decorada). Lamentam o fato de não poder ornamentar a igreja (proibido pelo bispo), pois acreditam que, ao entrarem na igreja para ver os enfeites, os devotos têm a chance de assistir a uma missa, ouvir a palavra etc. Isso atrai e complementa a festa que não teria graça sem os ornamentos.

A abertura da festa do Divino se dá com a abertura do império e o encerramento com a procissão de Pentecostes, por isso que a ornamentação é tão importante, dizem os coordenadores e concluem com a seguinte frase: "Nós queremos manter a tradição".

Há um esforço discursivo e nas ações de quem coordena a festa do Divino de Mogi das Cruzes em resgatar a origem da festa, manter a tradição e reconstruí-la a partir de imagens como o quadro do "Moço-Maio" - umas das pranchas de Jean Baptiste Debret ${ }^{11}$-, a música da dupla caipira sobre a bandeira do divino, um filme de Mário de Andrade de 1936 que mostrava a cavalhada em Mogi, as histórias sobre a origem da festa na Europa nos textos de historiadores e de folcloristas, as referências da bíblia, a presença da folia do divino, dos grupos folclóricos e de tudo aquilo que os dirigentes da Associação Pró-Divino chamam de "reminiscências do passado", como o imperador do divino representado por crianças, as bandeiras dos devotos, os carros de boi etc.

O tradicional discurso da tradição é evocado a todo instante pelas pessoas que organizam a festa. Porém, um dos lamentos ouvidos é que os organizadores da

\footnotetext{
${ }^{11}$ Criador da Bandeira Nacional, é considerado uma das principais figuras da missão artística francesa de 1818, trazida pelo governo português para promover no Rio de Janeiro a criação da Escola Real das Ciências, Artes e Ofícios. A prancha em questão é a de número $29 \mathrm{em}$ que aparecem os personagens da folia do Divino carregando um relicário, um saco de esmola e bandeiras com a pomba do Divino estampada. Essas e outras pranchas estão publicadas em Viagem pitoresca e histórica ao Brasil (1989).
} 
festa estão preocupados com o momento do aqui e agora e não pensam em manter a tradição, o que acaba gerando muitas perdas e distorções.

Para alguns críticos, a Associação Pró-Festa do Divino Espírito Santo é uma associação de ex-festeiros para ex-festeiros, uma espécie de "academia". Dizem que a associação, de certo modo, dá sustentação ao palanque político visto na festa e não está preocupada com os devotos. Todos querem fazer parte da associação porque ali está o grande mandato, pois o mandato de um ano como festeiro oficial dá mídia apenas durante um mês e na associação o mandato é quase perpétuo.

Talvez esse tipo de crítica esteja um pouco deslocado do conjunto de operações necessárias para a realização de uma celebração como a festa do Divino. Historicamente, as festas do Divino no Brasil afora - e outras manifestações do catolicismo popular - sempre dependeram da articulação de agentes leigos organizados em confrarias e irmandades religiosas, sem as quais a adesão popular não seria efetiva. Desde o século XVIII, brancos e negros fundaram irmandades como espaços associativos em torno dos santos de devoção (Silva, 2005). Por outro lado, o fato de identificar a Associação Pró-Divino como uma espécie de confraria não a torna menos legítima frente à igreja e aos devotos. Cabe aqui suscitar questões que ajudam a desvendar os processos de produção da festa como um espetáculo em nome da devoção e da manutenção da ordem social em nome da tradição.

\section{PERSONAGENS DEVOTOS}

Antes de prosseguirmos para os próximos capítulos, cabe uma breve apresentação de outros personagens da festa do Divino de Mogi das Cruzes. Essas pessoas estão ligadas, por um lado, à produção da festa como espetáculo e, por outro, à devoção ao Espírito Santo. Também aqui é difícil separar aqueles que fazem a festa daqueles para quem a festa é feita. Claro, está ligada à Associação Pró-Divino uma elite de 
classe média da cidade composta de empresários, comerciantes, funcionários públicos de maior renda e de políticos, ao passo que a grande maioria dos devotos e membros dos grupos que se apresentam na festa é composta de pobres, pequenos comerciantes, agricultores, operários e aposentados.

Como já foi dito acima, na casa da festa trabalham as "abelhinhas do divino". Esse nome carinhoso é dado para as mulheres voluntárias que trabalham incessantemente na preparação dos doces, bebidas e salgados vendidos na barraca da quermesse conduzida pela casa da festa. O trabalho das "abelhinhas" é essencialmente feminino. Dentre as "abelhinhas" há as doceiras, que cuidam somente da produção dos doces. O trabalho é voluntário, mas esse voluntariado é motivado por uma relação de gratidão ao Divino Espírito Santo. Muitas pessoas estão ali retribuindo graças alcançadas.

A divisão sexual do trabalho é marcada no interior da festa, sobretudo no que se refere aos trabalhos na casa da festa e ao trabalho religioso das rezadeiras. Além das conhecidas "abelhinhas", encontramos nas missas da novena assistentes chamadas de "divinetes", que são mulheres responsáveis pela preparação da igreja antes do início da missa, pela distribuição de panfletos na entrada, pelo auxílio às pessoas idosas etc. As "divinetes" são facilmente identificadas pelo uniforme que usam - elas vestem um terno vermelho com um broche do divino pregado na lapela e uma camisa branca, além de um crachá em que está escrito "acolhida". Nesse meio aparentemente inespecífico, onde se situa o trabalho das mulheres, há muitas funções e relações ocultas que delimitam esse meio e organizam a divisão do trabalho na festa do Divino a partir do gênero.

As rezadeiras fazem um trabalho religioso gigantesco junto aos devotos, elas são o elo de ligação entre a devoção ao Divino Espírito Santo e a igreja católica. O trabalho é ditado pelo bispo, pela casa da festa e por uma coordenadora que distribui as rezadeiras de acordo com os bairros e colabora na seleção dos textos bíblicos a serem lidos. As rezadeiras precisam ser registradas na casa da festa; não é 
permitido que qualquer pessoa saia rezando em nome do Divino Espírito Santo sem o aval da coordenação.

A denominação "rezadeira do divino" foi utilizada pela primeira vez em 1984, mas elas passaram a se constituir como um corpo organizado a partir do final da década de 1980. Porém, desde 1994, para ser uma rezadeira é preciso ter permissão e o registro na casa da festa. Hoje são quase setenta mulheres que percorrem as casas dos devotos meses antes da festa. Há dois ou três homens entre as rezadeiras (chamados de rezadores), mas os nomes deles são raramente lembrados. As rezadeiras cuidam do seu bairro, da sua região e atendem as pessoas nas casas. Não há um número específico de casas a ser visitadas, geralmente os trabalhos iniciam em meados de janeiro e terminam no dia primeiro de maio. Uma rezadeira percorre cerca de cento e vinte casas: multiplicando essa quantidade pelo número de rezadeiras (quase setenta) teremos mais de oito mil casas visitadas em Mogi das Cruzes num período de quatro meses.

Normalmente, a imagem do divino é levada no dia anterior para pernoitar com a família. O serviço religioso consiste, basicamente, na reza da coroa do divino (ver anexo), leitura de parte do evangelho indicada pelo bispo ${ }^{12}$ e execução de cantos em homenagem ao Divino Espírito Santo. Mas há algumas variações conforme observamos em campo, pois a prática de uma rezadeira vem da tradição oral e não de textos teológicos, embora haja um esforço em normatizar o trabalho delas por parte da igreja e da casa da festa. No final de uma reza sempre é oferecido café. Antes de ir embora, elas colocam nas caixinhas os pedidos que serão abençoados pelo bispo e queimados no encerramento da festa.

Nos dias nucleares da festa ou em ocasiões especiais, elas são obrigadas a usar um uniforme - terno azul e uma fita vermelha passando pelo pescoço. $\mathrm{Na}$ procissão de Pentecostes, carregam os pedidos em caixas e transportam um

\footnotetext{
$12 \mathrm{Na}$ festa de 2006, os textos bíblicos selecionados foram: Salmos: 22, 1-6; 24, 1-10; Atos dos Apóstolos: 1, 3-8; 2, 1-12; 8, 14-16; Epístola de São Paulo aos Romanos: 5, 1-8; 8, 26-27; Epístola de São Paulo aos Gálatas: 5, 16-26; Epístola de São Paulo aos Efésios: 1, 3-14; 4, 1-6.
} 
estandarte (introduzido em 2004). O trabalho de uma rezadeira tem sido tão eficaz e especializado que as pessoas querem receber sempre a mesma rezadeira em casa.

A festa do Divino Espírito Santo de Mogi das Cruzes conta com a presença de alguns personagens que são essenciais para a realização das cerimônias que compõem a festa. Alguns deles foram apresentados acima, mas outras figuras importantes são: o lanterneiro, o fogueteiro, a folia do divino, a banda Santa Cecília e os grupos de congada e de moçambique.

O lanterneiro organiza as caminhadas e os cortejos. As lanternas foram inventadas numa época em que os caminhos eram muito escuros e perigosos. As lanternas serviam para iluminar alguns obstáculos do caminho e sinalizar a chegada da folia do divino. Hoje, mesmo com a iluminação pública, as lanternas são usadas como o símbolo do fogo do Divino Espírito Santo e estão presentes na maioria dos eventos da festa. Nos cortejos das alvoradas e nas passeatas noturnas das bandeiras, são usadas seis lanternas brancas e uma lanterna vermelha que fica na mão do lanterneiro, que conduz o cortejo. Segundo o lanterneiro, o número sete representa os dons, sendo o branco e vermelho a representação das cores do divino. Em alguns casos, são usadas quatorze lanternas, seguindo a mesma lógica dos dons. Além das lanternas, as procissões contam com o apoio de soldados do Tiro de Guerra, da Guarda Municipal e do Departamento de Trânsito da Secretaria Municipal de Transporte da cidade, que fecha o tráfego para que as pessoas possam caminhar.

O fogueteiro é uma figura cada vez mais ausente da festa. Extremamente importante em outros tempos, nos últimos anos sua atuação tem se restringido à abertura do império e à procissão de Pentecostes.

A folia do divino é um grupo de cantadores e instrumentistas que sempre acompanha os devotos nas alvoradas e nas passeatas das bandeiras. Esses "sacerdotes de viola"13 são portadores de poderes mágicos e por onde passam levam a benção do Espírito Santo. A folia do divino que acompanha os devotos de Mogi das Cruzes é proveniente do bairro rural de Birituba Ussú. Tem sido freqüente

\footnotetext{
${ }^{13}$ Alusão ao livro de Carlos Rodrigues Brandão (1981a) sobre rituais religiosos do catolicismo popular em São Paulo
} e Minas Gerais. 
referir-se a eles como um grupo de "violeiros" no lugar de "folia". Atualmente, o grupo é composto por um mestre, um contra-mestre, um contralto e um tiple. O mestre é o responsável pela folia e toca viola; o contra-mestre faz a segunda voz e toca violão; o contralto integra o coro de quatro vozes e toca pandeiro; e o tiple, de voz aguda, toca a caixa. Atualmente, não recebem dinheiro para participar da festa. Nos últimos anos, receberam apenas camisas novas (de cor vermelha e com o nome da folia bordado), hospedagem em hotel e alimentação, além de combustível para o carro.

A folia do divino possui dezenas de cantos (ver anexo), compostos em pequenas quadras, tocados nas saídas das alvoradas e nas casas visitadas nas passeatas das bandeiras. As músicas da folia do divino são aparentemente parecidas para um ouvido desatento, porém o repertório varia em mais de 60 versos executados em ocasiões e momentos específicos. Por exemplo, disse-nos o mestre da folia que, se a casa ou o lugar visitado tem um império montado, uma bandeira, uma imagem do Espírito Santo, uma imagem de Nossa Senhora, velas acesas, cantam-se determinados versos; se na hora do lanche for servida bebida alcoólica, não se cantam outros versos; se alguma esmola for oferecida cantam mais versos, e por aí segue. A música chama-se Folia do Divino, mas há sempre versos de entrada e de saída, para abrir e fechar o império, de agradecimentos e despedidas etc.

A banda Santa Cecília, que existe na cidade de Mogi das Cruzes há mais de 60 anos, acompanha o festeiro nos momentos mais solenes, a saber, abertura do império, entrada dos palmitos, levantamento do mastro e procissão de Pentecostes. Atualmente, em Mogi das Cruzes, existem quatro grupos de congada e dois grupos de moçambique. São eles: o moçambique de São Benedito e Nossa Senhora do Rosário, do mestre José Tavares; o moçambique São Benedito, Bom Jesus e Nossa Senhora do Rosário, do mestre Benedito; a congada Santa Ifigênia, da mestre Gislaine; a congada Batalhão Nossa Senhora Aparecida, do mestre Nêgo Otaviano; a congada Nossa Senhora do Rosário, do mestre Dico; e a congada de São Benedito Império de César, do mestre Chico Preto. Os mestres das congadas e dos 
moçambiques são responsáveis pela direção dos grupos e alguns usam um apito como voz de comando nas apresentações. Todos os componentes do grupo se remetem a eles e a eles obedecem. São os mestres que marcam os ensaios, acertam as apresentações e os cachês. De posse deles ficam os instrumentos e os bens materiais, se houver.

O mestre da congada de São Benedito - Império de César nos contou que sua primeira participação na festa do Divino foi há 45 anos, já como mestre do grupo de congada. Ele se considera um grande católico, devoto de São Benedito e tem em sua casa, inclusive, uma pequena capela para São Benedito e Nossa Senhora Aparecida, onde faz suas orações e guarda os instrumentos e os cacetinhos ${ }^{14}$ do grupo.

A narrativa do mestre sobre a história da congada no Brasil é interessante. Para ele, a congada foi fundada no dia da libertação dos escravos, 13 de maio de 1888. Os escravos libertos e felizes celebraram esse momento com a dança e a música da congada e fizeram a princesa Isabel segurar a primeira bandeira do grupo, que passou a ser convidado para as festas de aniversário da princesa. Percebendo a beleza das danças, a igreja passou a se interessar por eles e também a convidá-los para apresentação. Mas os grupos precisavam de um santo de devoção. Então, uma irmã carmelita perguntou ao primeiro mestre de congada se ele não queria um santo para colocar na bandeira como padroeiro. Ele disse que não sabia qual santo colocar e que estava dançando somente com a bandeira que a princesa tinha dado. Então fizeram um sorteio com o nome de três santos: Nossa Senhora do Rosário, São Pedro e São Benedito. Quando o mestre puxou o primeiro nome saiu o de São Benedito. Por isso que toda congada tem que usar o nome de São Benedito. O mesmo aconteceu com o grupo de moçambique, quando o mestre fez o sorteio para escolher o santo padroeiro, saiu o nome de Nossa Senhora do Rosário.

No Brasil, seguindo a narrativa desse mestre, a congada surgiu primeiro na Bahia e depois foi para Minas Gerais. Daí em diante se espalhou pelo Brasil, mas em cada lugar ela é feita de um jeito diferente e usam-se instrumentos e manejos (a

${ }^{14}$ Bastões usados nas danças. 
batida dos cacetes) diferentes. Para ele, as danças são representações das lutas que os escravos conheciam e usavam para vencer guerras. Na África, apareceu outro grupo de congada que precisava de um santo. Então foram até a igreja pedir autorização. A irmã disse que havia uma escrava canonizada como santa, a Santa Ifigênia ${ }^{15}$, e sugeriu que colocassem essa santa como padroeira.

As cores da congada São Benedito - Império de César são amarelo, preto e vermelho. Perguntado sobre o significado das cores, o mestre não teve dúvidas e explicou: o amarelo é a cor do túmulo de São Benedito, o vermelho é o Divino Espírito Santo e o preto é da África. Para o mestre, sua congada foi a primeira a se apresentar na festa do Divino de Mogi das Cruzes. Ele disse que seu avô era escravo e conhecia a congada desde o tempo em que estava na África. Aos seis anos de idade, o atual mestre começou a acompanhar a congada que era comandada pelo pai e não parou mais. Hoje, a congada tem 48 componentes entre rei, rainha, mestre, contra-mestre, capitão, general, generalzinho e dançantes. Todos esses componentes são escolhidos por sorteio, que é realizado pela criança do grupo, chamada de generalzinho. A rainha sustenta a bandeira do grupo, o rei cuida da ordem dos componentes e das danças, o mestre e contra-mestre comandam os toques das músicas, o capitão comanda os manejos (danças e toques dos cacetinhos), o general não dança e não toca nenhum instrumento, ele fica de guarda e vem no final do grupo, auxiliando os dançantes e os tocadores, repondo algum instrumento quebrado ou perdido. Os principais instrumentos são: caixa, sanfona, repique, zabumba, chocalho, tamborim e os bastões.

Para o mestre da congada São Benedito - Império de César, o Divino Espírito Santo é o patrono de todas as festas e a maior inspiração do grupo. Eles tocam, cantam e dançam para o divino. Segundo o mestre, os congadeiros que não tiverem uma ligação com o Divino Espírito Santo não conseguem fazer os versos (que são quase todos improvisados), ficando quase impossível participar da congada. Para ele, existem mais de mil músicas, todas feitas e tocadas de acordo com as

${ }^{15}$ A congada Santa Ifigênia de Mogi das Cruzes tem as cores da bandeira da Nigéria, verde e branca. 
circunstâncias. Os componentes dos grupos aprendem as músicas e as danças em ensaios normalmente realizados na casa do mestre. Junto com as músicas são feitos os agradecimentos.

Em relação às músicas executadas, segundo Mário de Andrade, não há muito esforço por parte dos membros desses grupos em compreender os textos cantados que são repetidos por se saber decor. Para ele, "os textos vão se deformando por falhas de memória, assonâncias, associações, etimologias populares, etc., e ficam muitas vêzes irreconhecíveis" (1959, p.201).

As congadas e moçambiques são expressões de religiosidade e da cultura afro-brasileira presentes no Brasil desde o século XVIII. Segundo narrativas históricas, os reis e rainhas das congadas são representantes das nações de origem. O brasileiro, que se acostumou com a presença de "várias realezas" desde o século XIX, encontra nas congadas e moçambiques outros reis e rainha homenageados que contam outras histórias. Segundo Lilia Moritz Schwarcz, “além da metáfora mais imediata, que opõe colonizados a colonizadores, a congada representa um questionamento acerca da constituição de uma nação brasileira. Com efeito, a congada é um rito que fala muito sobre o Brasil do século XIX: dois povos ou duas nações se encontram em conflito ou em meio a alguma espécie e negociação" (1998, p.275).

Na festa do Divino de Mogi das Cruzes, esses grupos se apresentam na entrada dos palmitos com grande destaque e na procissão de Pentecostes sem o mesmo brilho. Como a própria história dos negros no Brasil, a participação desses grupos - fundamentalmente compostos por negros - no interior da festa é silenciada e, por vezes, suprimida. Para as apresentações, eles recebem uma pequena quantia em dinheiro, transporte e alimentação. Eles também se apresentam na quermesse numa das noites. 
Como notas conclusivas, poderíamos dizer que um ponto importante de mudança na organização da festa foi a passagem do ano de 1993 para 1994. Até então a festa tinha dimensões paroquiais, com a quermesse sendo realizada na praça em frente à igreja matriz, hoje catedral diocesana, sem patrocínios, sem a participação da imprensa e das escolas e sem essa estrutura empresarial encontrada atualmente. A fala de um diretor da associação resume bem essas mudanças: "aquela festa no largo da matriz, com as barraquinhas, tudo aquilo acabou por necessidade... é uma necessidade ditada pelo progresso. Até por questão de segurança, de acomodação, de logística e de preparação da quermesse não há a mínima condição de retornar àquela tradição de se fazer a quermesse no largo da matriz. Fica a saudade e a recordação daquele tempo".

Em 1994, ano de fundação da Associação Pró-Festa do Divino Espírito Santo, o festeiro foi uma pessoa ligada a uma universidade. Não por acaso a logomarca da Associação Pró-Divino é a reprodução de uma foto tirada na festa daquele ano. A imagem é a foto de uma pomba que pousou na coroa do festeiro no início da procissão de Pentecostes e só saiu ao entrar na igreja. Desde então, essa imagem passou a ser usada como símbolo da associação. Nesse mesmo ano, a quermesse foi realizada num local mais amplo, houve uma aproximação com a prefeitura, uma participação maior das escolas, propaganda em cartazes espalhados nos postes da cidade e a ajuda de patrocinadores, pois anteriormente era apenas o festeiro que promovia a festa, arcava com os gastos e com os eventuais prejuízos. Além disso, na última década, a imprensa começou a divulgar mais a festa, tendo como ponto alto a chegada de um canal de televisão local filiado à Rede Globo no ano 2000. A partir desse momento a festa não foi mais a mesma, dizem. Na medida em que esses veículos trabalham na divulgação da festa, acabam criando polêmicas. Uma matéria bastante comentada dizia respeito à proibição do uso de flores artificiais na decoração da igreja e uma outra matéria sobre uma suposta cobrança de ingressos para entrar na quermesse. 
Após os mandatos desses festeiros em 1993 e 1994, sentiu-se a necessidade de uma "moralização" e uma "sistematização" das crenças e práticas religiosas que envolviam a festa. A festa do Divino que hoje se sedimentou é fruto de pressões bastante específicas que trataram de colocar as coisas "em seus devidos lugares". Enfim, a fase empresarial da festa ganha uma racionalidade a partir do início da década de 1990. A divisão clara e circunscrita entre "religioso" e "folclórico" foi sendo elaborada a partir da década de 1980, embora já apareça em folhetos nas décadas anteriores.

As fronteiras que definem onde termina o culto religioso e começa a festa popular são extremamente borradas porque a cultura barroca da festa, conforme vimos, não separa o sagrado do profano. A festa opera como mediação sensível, sensual e estética de transmissão de uma visão de mundo. Para Maria Lúcia Montes, a "verdadeira cultura da festa, barroca em suas matrizes, impregna em profundidade o fazer e o sentir brasileiro, visível ainda, longe dos cânones eruditos da arte contemporânea dos museus, nas formas da chamada cultura popular (1998a, p.144, grifos da autora).

Como podemos perceber, a festa tem várias facetas. Aqui, nesse primeiro capítulo, buscou-se olhar para algumas delas. $\mathrm{O}$ procedimento alegórico inicialmente discutido buscava justamente expor a relativa coerência de integrar um mundo em ruínas a partir do esforço de alguns agentes produtores da festa que, ao empregar uma racionalidade cotidiana, produz um efeito de estranhamento em relação ao extraordinário. Em seguida, outras faces desse mosaico serão mostradas. A escavação continua. 


\section{VIVA O DIVINO ESPÍRITO SANTO!}

Concentrados em frente à casa do capitão do mastro, a banda Santa Cecília, os grupos de congada e de moçambique, as rezadeiras e alguns devotos viviam a expectativa da realização de um momento crucial na festa do Divino de Mogi das Cruzes. Estendido no chão estava o mastro a espera de ser levado à catedral de Santana para o seu levantamento. A procissão foi iniciada com o capitão do mastro seguindo a dianteira, juntamente com as lanternas e o festeiro, que conduziu o cortejo até a igreja carregando em suas mãos a bandeira que seria fixada na ponta do mastro. Essa bandeira, sempre vermelha, com a imagem da pomba e renovada a 
cada ano, tem um significado especial porque representa a descida do Espírito Santo na terra. O momento de levantamento do mastro, às 17 horas do sábado, horário simetricamente oposto ao da alvorada, marca o início da festa do Divino Espírito Santo tanto na liturgia como na tradição popular, pois o dia do Espírito Santo é exatamente a passagem do sábado para o domingo de Pentecostes. A festa dura um dia, o que vem antes é a preparação para este dia.

Em frente à catedral, no mesmo instante em que os batuques anunciavam a chegada do cortejo, o bispo já estava à espera do mastro para abençoá-lo. Segurando nas mãos um livro chamado "ritual de benção", o sacerdote realizou a benção do mastro com água benta, chamou para perto dele as pessoas que haviam carregado o mastro nos ombros e explicou o significado daquele gesto dizendo que, ao caminhar com o mastro, o homem dá um testemunho de sua prontidão perante Deus. Um dos voluntários que carregava o mastro estava muito emocionado e disse que não teria podido carregá-lo por causa de problemas na coluna, mas com a força do Espírito Santo conseguiu caminhar até o fim. Após o mastro ser abençoado, o bispo rezou e se retirou para dentro da igreja. Fez-se um grande barulho, ouviram-se gritos de “viva o Divino Espírito Santo!”, fogos espocaram no céu e a bandeira foi finalmente fixada no topo do mastro erguido em frente à igreja. Nesse momento, o mastro tornou-se o eixo do mundo. No mesmo instante, a banda Santa Cecília tocou, todos aplaudiram e se abraçaram. No final, o capitão do mastro convidou a todos para beber o licor rosa-sol.

Conforme foi dito no capítulo anterior, o rosa-sol é uma bebida avermelhada e extremamente doce, servida em pequenas doses somente após o levantamento do mastro. A receita e a técnica de preparo da bebida mágica são oriundas das pessoas da cidade que dizem tratar-se de um licor tipicamente mogiano. Tomar o rosa-sol tem um significado especial para alguns devotos porque sela o contato com o Divino Espírito Santo. Não se trata apenas de uma bebida típica, mas uma forma de relação estabelecida entre a cidade e o Espírito Santo que acabara de chegar. O rosa e o sol também podem ser entendidos como o encontro entre o branco e o vermelho, entre a pomba e o fogo, entre Nossa Senhora (rosa) e o Espírito Santo (sol). 
A devoção ao mastro é uma garantia de fertilidade e da continuidade da vida, daí o fato de o mastro ser tocado e beijado pelas pessoas que acompanham o cortejo. Ao anoitecer, um grupo de congada cantava em frente ao mastro músicas para a bandeira do divino. Em seguida, outra congada se apresentou diante do mastro e tocou com muita energia, evocando a presença e a proteção do Espírito Santo. Usando as palavras de Benjamin, ao falar da relação entre jogo e reflexão do drama barroco alemão, diríamos que o mastro conecta "a transcendência da fé a imanência da vida cotidiana" (1984, p.107).

Uma rezadeira que acompanhava a procissão de levantamento do mastro pegou um copinho do licor rosa-sol, bebeu um pouco, fez uma prece e jogou o resto no pé do mastro. Depois, novamente, pegou outro copo, jogou o licor no pé do mastro e girou em torno dele e ali permaneceu por um longo tempo rezando e acendendo velas. Tempos depois, ao encontrar essa rezadeira, tivemos a oportunidade de perguntar do que se tratava aquele gesto. A resposta foi surpreendente.

A rezadeira contou que um dia estava na casa de uma senhora e sentiu um forte cheiro de álcool. Incomodada com o cheiro, perguntou à dona da casa se havia alguma coisa de errado ou se ela tinha usado álcool para limpar a casa. A resposta foi negativa, a senhora disse que não havia problema algum e que não usava álcool na limpeza da casa. Tempos depois, a rezadeira descobriu que essa senhora tinha perdido um filho em decorrência do uso excessivo de bebida alcóolica. A rezadeira não teve dúvida de que o cheiro de álcool que havia sentido era por causa desse problema. Para a rezadeira, a alma daquela pessoa ainda estava ali e precisava ser ajudada a encontrar o caminho para o mundo dos mortos. Sendo assim, a rezadeira usou o mastro como um canal de comunicação entre os dois mundos através de um ato mágico, no sentido de Mauss, ao interpretar uma situação social num esquema mágico de significação do mundo.

A magia é definida por James Frazer no Ramo de Ouro (1982) como um sistema de lei de simpatia que se divide entre magia imitativa e magia por contágio. A magia imitativa homeopática (similaridade), para Frazer, seria a forma mais 
simples e elementar de magia: o semelhante produz o semelhante. Na magia contagiosa (contigüidade), há uma ligação entre o homem e qualquer coisa que pertença à pessoa. De posse desses elementos pode-se exercer influências sobre as pessoas. Mauss, em Esboço de uma teoria geral da magia (1974), concorda que as leis da magia são basicamente essas discutidas por Frazer (a contigüidade e a similaridade), mas introduz uma terceira lei que é a de contrariedade ou de oposição, ou seja, ao derramar água provocaria chuva e eliminaria a seca. O contrário é anulado pelo contrário. A rezadeira, ao derramar uma pequena porção de licor no pé do mastro na tentativa de eliminar o problema da alma inquieta do jovem, operou na lógica da magia simpática: álcool para eliminar álcool. Mas tem um detalhe que torna essa operação mais complexa que é a relação entre o mundo dos vivos e o mundo dos mortos, ou seja, há uma combinação entre simpatia e contrariedade, ocorrendo um intercâmbio entre um sistema e outro.

Para Mauss, a concretude da magia está nos experimentos, na associação de idéias através de cores, de objetos, de espíritos, de classes etc., enfim, a magia também é um sistema de classificação cuja eficácia está assentada em sua crença. Nela, se crê ou não se crê. Numa afirmação que parece antecipar algumas conclusões de Lévi-Strauss presentes em dois artigos de Antropologia estrutural (1967), “A eficácia simbólica" e "O feiticeiro e sua magia", Mauss afirma que os poderes do sacerdote são definidos pela religião, enquanto a imagem de poder e eficácia do mágico é produzida fora da magia, pela sociedade envolvente que confia e deposita sua fé em suas capacidades místicas.

Para Mário de Andrade, a ereção do mastro "é objéto de cerimonia especial, enumerada no programa impresso das festas, e realizada no mesmo dia (á tarde) da Entrada dos Palmitos. Porque no mesmo dia? e porque êsse dia, si a festança já durava uma semana? Me parece evidente a subsistência duma lei tradicional que está agindo sempre, embora todos lhe ignorem a significação primitiva" (1937, p.55, grifo do autor).

Talvez Marshall Sahlins (1990) nos ajude a responder as questões de Mário de Andrade. O autor conta a história da luta do herói maori Hone Heke pela 
derrubada do mastro britânico. O mastro era a causa da guerra e tinha a ver com a posse da terra. Segundo Sahlins, "para que possamos decodificar a preocupação de Heke com o tal do mastro, será necessário voltarmos às origens do universo" (p.8). Para os maori, o mastro significava domínio ancestral da terra. Na mitologia, um local sagrado (tūāhu) é marcado com a ereção de um poste ou um conjunto de postes (pouahu), que representava prestígio e estabilidade do povo instalado naquele lugar. Por outro lado, para os ingleses, o mastro apenas sustentava a bandeira do império britânico cujas cores demonstravam a soberania da rainha. Para os maori, o fato de os ingleses erigirem um mastro naquele lugar significava a possessão simbólica da terra e isso era inaceitável porque o mundo onde eles habitavam tinha sido herdado através da relação entre a Mãe Terra (Papa) e o deus Tāne, responsável pelo surgimento da humanidade. De modo que lutava-se pelo mastro como garantia de fertilidade, preservação da vida e comunicação entre o céu e a terra.

A mesma rezadeira da qual falamos há pouco tem uma devoção muito especial para com o mastro e costuma realizar junto dele outros atos, como o descrito acima, a pedido das pessoas e, inclusive, canta uma louvação no momento de erguê-lo que começa assim: Chegôô, Chegôô... a bandeira do mastro chegô. Chegôô, Chegôô... capitão do mastro chegô. Louvêmo, louvêmo com muita alegria. Louvêmo, louvêmo com muita alegria. Louvêmo esse santo hoje aqui nesse dia. Que santo é esse que vamos louvar? É o Espírito Santo para festejar. Mas que santo é esse que vamos louvar? É o Espírito Santo para festejar.

O que se procura entender nesse capítulo é a presença do Espírito Santo na vida das pessoas e a força da devoção expressa em diversos momentos da festa. Afinal, o que é esse Divino Espírito Santo? Por que tanta devoção? Comecemos pelas suas definições. 


\section{O DIVINO ESPÍRITO SANTO}

O Espírito Santo, celebrado na festa, é a terceira pessoa da Santíssima Trindade no cristianismo. Segundo o Léxico das Religiões (1998), para o Novo Testamento, o Espírito Santo é experimentado como um dom escatológico em que Deus presenteia o seu povo através do Messias (Jesus Cristo). Este tem a missão, através da fé no Senhor, de libertar o povo da servidão do pecado, da culpa e da morte, em busca da salvação. A doutrina do Espírito Santo, presente não somente no proselitismo da igreja católica, dá ênfase numa experiência religiosa mais emotiva e catártica, consiste em manifestação de cura e glossolalia.

Na liturgia, o Pentecostes é a conclusão de um período dedicado à paixão, morte, ressurreição e ascensão de Jesus Cristo aos céus. Portanto, a vida humana de Cristo se encerra com essa subida aos céus, mas para tal necessitou da ação divina do Espírito Santo (a mesma ação que, através da Virgem Maria, o concebeu). De volta à terra, o tempo do Espírito Santo é anunciado quarenta dias após a Páscoa, o dia conhecido como Ascensão do Senhor. A bíblia apresenta esse momento no livro Atos dos Apóstolos, na seguinte passagem: "Foi aos apóstolos que Jesus, com numerosas provas, se mostrou vivo depois da sua paixão: durante quarenta dias apareceu a eles, e falou-lhes do Reino de Deus. Estando com os apóstolos numa refeição, Jesus deu-lhes esta ordem: ‘Não se afastem de Jerusalém. Esperem que se realize a promessa do Pai, da qual vocês ouviram falar: ‘João batizou com água; vocês, porém, dentro de poucos dias, serão batizados com o Espírito Santo'. Então, os que estavam reunidos perguntaram a Jesus: 'Senhor, é agora que vais restaurar o Reino para Israel?' Jesus respondeu: 'Não cabe a vocês saber os tempos e as datas que o Pai reservou à sua própria autoridade. Mas o Espírito Santo descerá sobre vocês, e dele receberão força para serem as minhas testemunhas em Jerusalém, em toda a Judéia e Samaria, e até os extremos da Terra'" (At: 1, 3-8).

Segundo um sacerdote de Mogi das Cruzes, essa terceira pessoa da Santíssima Trindade - o Espírito Santo - tem o dever de cumprir e completar a obra de Jesus Cristo na terra através de dois motivos: iluminar (lembrar tudo que Cristo 
pregou e fez) e fortalecer (para que os fiéis sejam firmes no Evangelho). O Espírito Santo é, portanto, uma ação concreta na vida das pessoas cujo objetivo seria iluminar a mente e fortalecer a vontade dos homens. O Espírito Santo é representado pela pomba e pelo fogo, mas concretamente trata-se de uma ação divina efetivada no momento em que houve a descida desse espírito sobre os apóstolos cinqüenta dias após a ressurreição de Cristo através de línguas de fogo, o Pentecostes.

Na bíblia, o Pentecostes aparece da seguinte maneira: “Quando chegou o dia de Pentecostes, todos eles estavam reunidos no mesmo lugar. De repente, veio do céu um barulho como o sopro de um forte vendaval, e encheu a casa onde eles se encontravam. Apareceram então umas como línguas de fogo, que se espalharam e foram pousar sobre cada um deles. Todos ficaram repletos do Espírito Santo, e começaram a falar em outras línguas, conforme o Espírito lhes concedia que falassem" (At: 2, 1-4). Essa passagem bíblica significa, inclusive, o próprio nascimento da igreja católica.

Para alguns teóricos (antropólogos, sociólogos, filósofos e teólogos), o culto ao Espírito Santo tem suas bases teológicas nas concepções do monge calabrês do século XII, Gioacchino Da Fiore (Joaquim de Fiore). Segundo Carlos Rodrigues Brandão, as idéias joaquimistas "incorporam basicamente um esquema de caráter apocalíptico, onde o mundo se divide em três grandes eras: a Idade do Pai ou da Lei, originada na Criação e terminada com a obra redentora de Jesus Cristo; a era do Filho ou do Evangelho, próxima do seu final; e a era do Espírito Santo, ou do Evangelho Eterno" (Brandão, 1978, p.143, nota 50).

Segundo Robert Nisbet, em estudo sobre a história da idéia de progresso, o pensamento medieval, que aparentemente esteve fascinado pela contemplação do paraíso celeste, encontrou em Joaquim de Fiore a mais poderosa profecia do paraíso terrestre em termos apocalípticos. Nisbet comenta que “o paraíso terrestre mais influente e mais interessante é aquele estabelecido no tempo, profetizado para o futuro, na Terra" (1984, p.105). Para o autor, citando um historiador que pesquisou a influência das concepções joaquimistas no pensamento medieval, diz que: “O 
significado histórico de Joaquim reside na qualidade dinâmica de algumas idéias chaves que ele proclamou. Essas idéias continuaram a exercer sua ação de forma discreta, durante os séculos seguintes: de vez em quando subia à tona em um grupo ou indivíduo. A sua qualidade vital deriva do fato de que elas mexeram com a imaginação, movimentando o homem em direção à esperança e, consequentemente, em direção à ação; assim, seu impacto foi mais emocional que intelectual" (Reeves, apud Nisbet, 1985, p.106).

Retomando a formulação das três eras mencionadas por Brandão, podemos reformulá-la, citando Nisbet, da seguinte maneira: “A primeira grande etapa da história humana é caraterizada pelo que chama de 'ascendência da carne', com suas imperiosas solicitações mantendo, quase sempre, a consciência do homem seu nível material. Essa primeira idade durou até o aparecimento do Cristo. Na segunda etapa da história, 'os homens viveram entre a carne e o espírito'. Tendo sua origem no primeiro aparecimento do Cristo, a segunda idade dura até os nossos dias, e seu fim não vai ocorrer sem um período de grande agitação na sociedade - violência, terror, medo e sofrimento. Só através dessa dor e desses tormentos será possível à humanidade purificar-se e preparar-se para terceira idade, que é a maior delas: a do espírito, em que os seres humanos (todos os cristãos, é claro, mas o resto da humanidade, incluindo os judeus já convertidos) terão se tornado contemplativos vivendo inteiramente através da mente. Joaquim escreve que a Idade dos Contemplativos significará o Céu descendo à Terra" (1985, p.107).

Na Idade do Espírito, a vida seria vivida segundo os valores comunitários em que imperariam a caridade, a unidade e o partilhar de todas as coisas na terra: o céu descerá à terra. Além disso, com a vida espiritual e contemplativa desenvolvidas, cada indivíduo seria capaz de entender o evangelho e interpretar as verdades religiosas sem a necessidade de sacerdotes, por isso que as idéias de Joaquim de Fiore foram perseguidas, julgadas heréticas e condenadas pelo Concílio de Latrão. As idéias joaquimistas se difundiram na Europa no mesmo período do surgimento do franciscanismo, por volta de 1200, e chegaram ao Brasil nos 
primeiros tempos da colonização através dos missionários franciscanos no século XVI.

Essas idéias revolucionárias propiciaram o aparecimento de monges místicos que pregavam um reino de amor e abundância na terra com forte apelo nos movimentos milenaristas em diversos lugares do mundo. Para Victor Turner (1974b), é significativo que muitos líderes espirituais (ele falava dos franciscanos) tenham tido contato com as obras de Joaquim, que se baseavam em noções de crises e catástrofes. Essas idéias contribuíram para a construção do sentimento de "communitas", que buscava justamente resistir contra o breve advento do fim do mundo. Desse modo, não é por coincidência que o culto ao Espírito Santo esteve na base da revolta popular do Contestado no Sul do Brasil, que misturava concepções joaquimistas e sebastianistas, associando a Idade do Espírito Santo com o combate entre mouros e cristãos dos doze pares de França na defesa do império de Carlos Magno (batalha simulada pelas cavalhadas) (Monteiro, 1974).

Segundo José de Souza Martins, a guerra do Contestado deu provas claras de que uma "devoção religiosa inofensiva, ingênuo teatro popular, como a cavalhada, continha na verdade fortes elementos revolucionários, nítidos para os participantes, invisíveis para os inimigos" (1989, p.120).

Nas formulações de Joaquim de Fiore, o tempo cristão é limitado, temporário e está chegando ao seu fim, mas antes passaria por um período de violência e guerra. O tempo presente está repleto de mal e precisa ser encerrado para que um novo tempo - a Idade do Espírito - seja instaurado. Essa energia contida alimenta as expectativas messiânicas e a necessidade de um Novo Messias que realize as mudanças desejadas. A entrada num novo tempo seria conduzida por um salvador que durante os últimos séculos se personificou na figura de um imperador suficientemente capaz de conduzir a humanidade ao novo tempo.

Um imperador forte estabeleceria na terra o império do Espírito Santo e um tempo de igualdade, de justiça e, principalmente, de fartura. Esse tempo abençoado de caridade e concórdia entre os homens é anunciado e celebrado nas festas em louvor ao Espírito Santo. 
Em muitos textos, sobretudo de folcloristas, encontramos a instauração da festa a partir de um ato de benevolência da Rainha Isabel, esposa de Dom Dinis, rei de Portugal entre os anos de 1261-1325 - período de maior influência das idéias de Joaquim de Fiore na Europa. Para Alceu Maynard Araújo, a origem da festa em Portugal se deu com o "milagre das rosas". Nas palavras do folclorista: "Conta-nos a lenda que a rainha gostava de dar esmolas aos pobres. (Dom Dinis era um 'bardade-farelo', 'pão-duro', conforme a gíria atual.) Ao derredor do palácio sempre havia pedintes. O rei proibiu tanta prodigalidade. Certa feita, Isabel, carregando no regaço uma quantidade de côdeas de pão para distribuí-las aos pobres, depara com o rei. Este pergunta-lhe o que levava na abada. 'Levo rosas', respondeu a rainha caridosa. O rei quer ver. E vê rosas, rosas lindas!" (2004, p.28). O autor nos traz o mito de origem das celebrações ao Espírito Santo e da farta distribuição de alimentos encontrada na maioria das festas no Brasil.

O ano eclesiástico da igreja católica romana determina certos dias para o culto divino. Esses são os dias de festa que se distinguem em dois grupos: as festas para o Senhor e os dias de comemoração aos santos. As festas para o Senhor rememoram momentos e episódios da vida de Cristo, como o nascimento, a paixão, a morte e a ressurreição. Algumas dessas festas têm suas datas móveis, outras são fixas. A festa do Divino Espírito Santo é uma festa para o Senhor e tem sua data de realização móvel condicionada ao calendário religioso, realizada na maioria dos casos ao sétimo domingo (ou cinqüenta dias) após a Páscoa.

Não há dúvidas de que a festa do Divino é eminentemente religiosa conforme encontramos na liturgia, na devoção das pessoas, nas pesquisas dos folcloristas e em trabalhos acadêmicos. Porém, suas origens estão em camadas mais profundas da história da humanidade, com um passado que nos remete ao panis gradilis dos gregos e às comemorações da Páscoa judaica, ligada ao calendário agrícola: a "festa da colheita, dos primeiros frutos". Segundo Araújo, a Páscoa judaica é "celebrada cinqüenta dias após o décimo sexto dia do mês de nisan hebraico, dois dias após a celebração da Páscoa, daí os rabinos chamarem-na de 'festa dos cinqüenta dias'” (2004, p.37). No Brasil, a festa do Divino é realizada no 
solstício de inverno - também época de colheita (maiores ganhos, maiores gastos) -, daí o predomínio do consumo de alimentos, de alegria e de pagamento de promessas. Para Maria Lúcia Montes, a festa do Divino Espírito Santo é uma “celebração da abundância bem mais próxima de antigas tradições pagãs e que o cristianismo integra ao calendário litúrgico para neutralizar o poder de permanência da crença herética" (1998b, pp.105-106). Trata-se, portanto, de uma festa em que o agradecimento pela abundância domina a celebração, renovando as esperanças para que no ano seguinte as coisas possam acontecer da mesma forma.

Para alguns representantes da igreja católica em Mogi das Cruzes, a devoção ao Espírito Santo na cidade em forma de uma festa está no campo da cultura. Para eles, independentemente da festa, as pessoas deveriam buscar uma vida em santidade através da ação do Espírito Santo. Para um padre da cidade, o que ele chama de "cultura" nunca foi um problema para a igreja. Segundo o sacerdote, os atos de devoção realizados na festa são expressões de fé através da cultura, mas se o devoto não acreditar em Deus nunca terá uma vida em santidade. Os sacrifícios feitos durante a festa em si não são um sinal de santidade, mas sim o que está por trás desses atos, ou seja, a demonstração de fidelidade a Deus e à igreja católica. $\mathrm{Na}$ avaliação do sacerdote, o trabalho das rezadeiras são atos de amor e expressão de fé, um modo de agradar a Deus. E finaliza dizendo que para fortalecer a fé não basta participar da festa, é preciso ir às missas, rezar etc.

O discurso do padre, acerca da cultura, está de acordo com as mudanças da igreja católica a partir do Concílio Vaticano II, realizado em 1960-1965, em que a igreja se reconcilia com o mundo moderno (Montero, 1995) e coloca no centro do debate a questão da cultura em termos antropológicos e não mais em termos etnocêntricos, isto é, passa a considerar as culturas em suas pluralidades. Após uma série de mudanças decorridas do pós-guerra, a igreja renova o seu interesse pela cultura na tentativa de se manter como uma instituição articulada com as questões do mundo contemporâneo.

No entanto, a visão da igreja ainda continua centrada na universalidade da fé a partir dos parâmetros estatuídos em Roma. Segundo o depoimento de um ex- 
bispo, a participação dos chamados grupos folclóricos na festa do Divino de Mogi das Cruzes é como uma espécie de "moldura". A metáfora da moldura é, com efeito, um emblema bem adequado da visão da igreja: ela delimita o lugar de aparição e define o que é visível e o que está à margem. Eles ficam na moldura porque estão de fora do recorte canônico. Sua visão é a do palco à italiana (Pasta Jr., 1999).

\section{EXPRESSÃO GERA EXPERIÊNCIA}

Para um devoto de Mogi das Cruzes não basta ter fé e acreditar no poder do Divino Espírito Santo, é preciso demonstrá-la. Os atos de devoção são vivenciados durante os onze dias de festa em diversas ocasiões. Separamos aqui alguns momentos registrados no caderno de campo e destacamos fragmentos de situações ocorridas nas alvoradas, nas missas da novena e nas passeatas noturnas das bandeiras.

Com exceção das missas, esses momentos têm como mais importante o ato de caminhar, a peregrinação, que reatualiza o mito fundador da igreja católica (Sanchis, 1992). O ato de peregrinar está na matriz da igreja católica desde os tempos da luta contra o paganismo. A peregrinação transborda fronteiras e reconstitui unidades num espaço imaginário. Segundo Paula Montero, a peregrinação dos católicos refaz no tempo e no espaço a unidade de um reino historicamente fragmentado. Para a autora, "peregrinar é desambular, andar. Reconstruir no espaço geográfico a mesma unidade que se constrói no tempo mítico pela História" (1995, p.244). Assim, iniciamos a caminhada pelas alvoradas.

AS ALVORADAS As alvoradas se iniciam às 5h da manhã. Antes desse horário, aos poucos, os devotos vão chegando e se concentram na praça em frente à catedral 
de Santana. Em primeiro lugar, o festeiro e o capitão do mastro, juntamente com o grupo da folia do divino, entram pela porta da direita do império do divino, fazem a oração de abertura e saem pela porta da esquerda. Do lado de fora, o lanterneiro espera a saída do festeiro e organiza o cortejo com seis lanternas brancas e uma vermelha, perfilado em duas filas. Além das lanternas, a procissão ainda conta com o apoio de soldados do Tiro de Guerra, guardas da Guarda Municipal e do Departamento de Trânsito da Secretaria Municipal de Transporte da cidade, que fecha o tráfego. O cortejo inicia a caminhada com o festeiro e o capitão do mastro à frente, em seguida vem a folia do divino, que inicia um canto em forma de prece (ver anexo), o carro de som e algumas pessoas encarregadas de iniciar as orações e os cantos. Atrás, seguem todos os devotos com as bandeiras em punho. A procissão da alvorada é montada da seguinte maneira: primeiro, a folia do divino canta; depois, reza-se a coroa do Divino Espírito Santo: a cada dom rezado canta-se uma música que anuncia o dom a ser rezado. Em seguida, fazem-se as Três invocações à Maria Santíssima, a Oração ao Divino Espírito Santo e a Oração a Nossa Senhora. (ver anexo).

Terminada essa parte das orações, se a procissão ainda estiver andando, prossegue-se cantando. A primeira música a ser cantada é sempre a Bandeira do Divino, de Ivan Lins e Vitor Martins. Outras músicas bastante cantadas são: Eu navegarei, Vem Espírito Santo, A nós descei divina luz, Estaremos aqui reunidos, Calix Bento (que também é chamada de Saudação da morada e Oratório), Deixa a luz do céu entrar, Segura a mão de Deus e Oração pela família. (as letras das músicas estão em anexo.) Essas músicas não têm uma ordem ou momento específico para serem executadas, cantam-se de acordo com a conveniência do lugar e da ocasião. Acontece, em alguns casos, de algum devoto iniciar uma música e o resto do grupo tende a acompanhar, mas geralmente há pessoas designadas para esse trabalho.

Ao chegarem de volta ao ponto de onde partiram - quase uma hora depois o festeiro, o capitão do mastro e a folia do divino entram novamente no império, rezam, fazem os agradecimentos e convidam os devotos para um café da manhã que 
é servido no salão paroquial da catedral. Ao final da oração, o dia amanhece. Já nesse momento, na porta do salão paroquial, forma-se uma longa fila; cerca de mil pessoas todas as manhãs estão à espera do café. A fila anda rapidamente e logo enche o salão. $\mathrm{O}$ "café do divino", como é chamado, conta com o trabalho voluntário das "cafezeiras" que, às 4 h da manhã chegam à igreja para iniciar os preparativos. $\mathrm{O}$ "café do divino" consiste em café preto, pão com mortadela e três biscoitos conhecidos como "biscoito do divino" (também chamado de "cangalha" ou "cangalhinha") que são servidos ainda na fila, mas que as pessoas geralmente não comem, acabam levando para casa, pois acreditam que estes sejam abençoados. Antigamente, só era distribuído o biscoito, recentemente passaram a distribuir pão com mortadela. O café não é servido antes da chegada do festeiro e do capitão do mastro. Na porta, uma pessoa organiza a fila e auxilia a distribuição dos biscoitos e pães. Todos os dias são preparados 1.500 pães com mortadela. Se, por acaso, sobrar alguns, esses são doados. Antes ainda de o café ser servido, e já com a presença do festeiro, faz-se um agradecimento e reza-se de novo.

O MILAGRE DO PÃO Conforme cartaz fixado acima da porta da cozinha, o verdadeiro "milagre do pão" é realizado durante as nove manhãs de alvorada em que o café comunitário é servido para os devotos. O pequeno salão paroquial em poucos minutos fica completamente lotado. Do lado oposto das portas de entrada (são duas), há mesas onde as pessoas esperam de pé com xícaras nas mãos o momento de serem servidas. No fundo, foi montado um subimpério com diversas fotos, incluindo uma do Papa João Paulo II. Do outro lado do subimpério, fica a cozinha de onde saem os voluntários que servem o café. O pão, como já dissemos acima, é distribuído na entrada do salão. Esses pães são doados por 14 padarias da cidade. Por volta das 6 h30min, boa parte do café já foi servido, mas muita gente ainda tem de aguardar do lado de fora do salão o momento de entrar. 
Todas as manhãs parece que não haverá pão e café suficientes para todos, mas, inacreditavelmente, todos são servidos por, pelo menos, um pão francês com uma fatia de mortadela e uma xícara de café preto. Por volta das 7 h, o café já foi servido, todos os devotos estão saciados e o salão pouco a pouco se esvazia.

DIREÇÕES E OLHARES Para Marcel Mauss, "localizamos no espaço nossas representações do mundo sensível" (2001, p.399). Aparentemente as alvoradas são iguais e repetitivas, ocorrem durante nove madrugadas seguindo o padrão descrito acima. Mas as coisas não são tão simples como as aparências mostram. Cada alvorada tem um significado na vida dos devotos e na própria vida da festa do Divino. Os percursos percorridos demonstram mais do que caminhos. Todas as manhãs, a montagem da alvorada segue o padrão já descrito: a folia inicia o canto, reza-se a coroa do divino, intercalando com a música "Senhor, vem dar-nos", saindo do império e voltando ao mesmo ponto. As direções seguidas, no entanto, mudam a cada dia. Os trajetos são fixados na parede externa do império e indicam as ruas a serem percorridas. Normalmente, obedece-se o sentido horário, da direita para a esquerda em forma de círculo (com raras exceções, caminha-se em sentido antihorário). São percorridas, geralmente, as principais ruas do centro da cidade em torno da catedral de Santana. Outro detalhe interessante é que a procissão segue a mão do fluxo do trânsito conforme as normas da lei de trânsito e nunca entra na “contra-mão".

Freqüentemente, as alvoradas ocorrem sob forte neblina e com temperaturas bem baixas. Centenas de devotos se reúnem na praça e, com o lanterneiro à frente, juntos partem em procissão. Felizmente não há termômetros por perto para saber a temperatura nesse instante, pois o frio é intenso e o chão, por vezes, encontra-se molhado por causa do sereno da noite. A combinação entre madrugadas frias e pessoas idosas por vezes acaba gerando situações de preocupação. Não raro, 
pessoas passam mal durante a procissão e são socorridas com urgência e levadas à Santa Casa.

Observamos que há muitas famílias, alguns casais, mas também muita gente sozinha, sobretudo pessoas idosas, caminhando juntas nas madrugadas frias das alvoradas. Na medida em que a procissão passa na frente das casas, muitas pessoas, recém-acordadas, olham curiosas através das janelas entreabertas.

Destacamos duas alvoradas significativas que tocam em dois pontos fundamentais do catolicismo encontrado na festa do Divino de Mogi das Cruzes: o poder da cura e a relação entre a vida e a morte.

Há uma alvorada que parte em direção à Santa Casa de Mogi das Cruzes. A procissão segue até o hospital e pára. Lá, os devotos fazem uma oração especial para os doentes. Rezam para os médicos, para todos aqueles que trabalham para a saúde e na luta contra os males do corpo e do espírito. Interessante: rezam para o "progresso da ciência". O festeiro normalmente se dirige às pessoas internadas, aos médicos e enfermeiros e pede para que o Divino Espírito Santo aja sobre os doentes e diminua as filas de espera para os que precisam de atendimento médico. Em seguida, partem cantando e rezando para os desempregados, para as crianças, os jovens, os presos, para o Papa Bento XVI, para o bispo e todos os sacerdotes, para Nossa Senhora Aparecida, para o casal de festeiros, capitães do mastro e todos os colaboradores da festa.

De acordo com Lévi-Strauss (1967), a eficácia do poder da cura está assentada em sua crença. Claro, sabemos que o autor falava do complexo xamanístico e na crença da força da magia que se revela nos procedimentos técnicos do feiticeiro. Em nosso caso, a presença do festeiro no hospital envolve a crença da coletividade que confia em sua eficácia. O festeiro, assim como o xamã, está de posse de um mecanismo que interpreta e ordena as fases do mal desde o diagnóstico até a cura. Para Lévi-Strauss, não importa o quão absurda seja essa interpretação, o fundamental é que o doente acredite nela e faça parte de uma sociedade que também acredite. Há que se considerar que o doente em questão não apenas se 
resigna com o sistema explicativo produzido pelo xamã em questão. Ele, de fato, sara.

A segunda alvorada que destacamos é realizada num cemitério da cidade. A procissão parte em direção ao cemitério de São Salvador que fica num ponto alto da cidade e conta com um grande número de devotos com bandeiras nas mãos. Durante o trajeto observa-se a mesma estrutura descrita. Quando os devotos chegam ao cemitério, o bispo e seus auxiliares já os aguardam para uma missa especial em homenagem aos mortos que participaram da festa no passado.

A missa presidida pelo bispo tem algumas músicas específicas cantadas à capela. Segue-se a liturgia normal de uma missa, com leitura do evangelho, ofertório e comunhão. Na homilia da missa de 2005, o bispo falou que, para aqueles que morreram, a igreja é triunfante, pois já estão no reino dos céus e discorreu, tal como em outros momentos, sobre a importância da festa do Divino para Mogi das Cruzes ser de um "jeito próprio" e representar as tradições da cidade. Para o bispo, cada festa realizada deveria ser vivida como se fosse a primeira. Nas palavras do bispo, pouco a pouco, a cada ano, é possível purificar e melhorar em relação às coisas que vêm de Deus. Ainda durante a homilia, o bispo falou que a igreja católica é uma igreja peregrina. Enfatizou a idéia de simplicidade e pureza, o papel dos jovens e das crianças e celebrou a passagem entre a vida e a morte.

A missa no cemitério não serve apenas para lembrar dos que já morreram, mas para evocar os espíritos dos antepassados e visitar esses mortos que renascem como esperança para os que ainda estão vivos, le mort saisit le vifit ${ }^{16}$ A sobrevivência material da comunidade, sobretudo em sociedades rurais, é assegurada na relação com o mundo dos mortos e no controle mágico das forças da natureza. Nesse momento, vivos e mortos estão reunidos numa mesma comunidade de sentidos.

A morte ocupa um lugar privilegiado no campo religioso brasileiro. Para Oscar Sáez, “a proximidade dos mortos é correlativa às grandes distâncias entre os vivos, e daí lhe advém a centralidade. Os mortos servem de mediadores nessa

\footnotetext{
16 "O morto apodera-se do vivo". Esse conceito é utilizado por Pierre Bourdieu (1989) para falar sobre a relação entre história reificada e história incorporada. A noção de história incorporada é interessante porque ajuda a pensar o modo como o passado é atualizado no presente sem necessariamente saber que está se trazendo de volta.
} 
paisagem porque através deles - e de seus veículos, da psicografia à reencarnação é possível redesenhar qualquer relação e qualquer conflito na escala mínima das relações familiares e vizinhança" (1996, p.186). Ao falar da morte e dos mortos na sociedade brasileira, José de Souza Martins afirma que “a hora da morte é um momento de grande tensão e muito conflito. É nela que se trava a grande batalha entre Deus e o Diabo, entre o bem e o mal, entre a salvação e a perdição" (1983, p.262).

É uma sensação estranha chegar num cemitério ainda escuro e amanhecer assistindo a uma missa na qual são evocados os espíritos de ancestrais que participaram da festa do Divino em tempos passados. De início é um pouco assustador, pois não se vê muita coisa e, como o lugar era desconhecido para o pesquisador, não dava para saber exatamente onde estava entrando. Lentamente, os primeiros raios de luz aparecem por entre as nuvens colorindo o céu em tons vermelhos, rosados e amarelos. O dia amanhece ainda durante a missa num lugar muito bonito. Após a missa, a procissão retornou ao império por volta das $6 \mathrm{~h} 30 \mathrm{~min}$. Na volta, ao passar em frente à Santa Casa (cujo nome é Nossa Senhora Aparecida), a procissão parou e rezou um Pai-Nosso, uma Ave-Maria, cantou a música Calix Bento e prosseguiu. Após a Santa Casa, vem o Batalhão da PM. Lá não pararam, mas rezaram um Pai-Nosso e uma Ave-Maria. Ao chegar no império, por volta das 7h, a folia fez a despedida e todos foram tomar o café.

Segundo Edmund Leach, “em todos os lugares, as crenças religiosas estão ligadas com a discriminação entre os vivos e os mortos. Logicamente, a vida é simplesmente a antítese binária da morte: os dois conceitos são as duas faces da mesma moeda e não podemos ter um sem o outro. Mas a religião sempre tentou separar os dois. Para tanto, ela criou um hipotético 'outro mundo', que é a antítese 'deste mundo'. Neste mundo, a vida e a morte são inseparáveis; no outro mundo, elas são separadas. Este mundo é habitado por homens mortais e imperfeitos; o outro mundo é habitado por não-homens imortais (os deuses)" (1983, p.181, grifos do autor). 
Para Carlo Ginzburg (1991), durante a Idade Média e na Renascença, o Pentecostes era um período consagrado aos mortos, significava uma visita ao mundo dos mortos, um movimento de ir ao além e voltar. Esse Pentecostes é o mesmo que aparece na bíblia, ou seja uma língua (um veículo de comunicação) por meio da qual deuses e homens (e demônios) se comunicam.

Rezar para os mortos é rezar pelas almas que estão no purgatório, em situação de liminaridade. Desse modo, pede-se ao Espírito Santo que interceda por aqueles que sofrem provações liminares no purgatório e pelas almas já salvas.

AS MISSAS DA NOVENA A primeira missa da novena é geralmente presidida pelo bispo diocesano de Mogi das Cruzes e pelo pároco da catedral de Santana. A igreja é preparada com uma decoração simples e discreta, faixas vermelhas penduradas nas colunas que sustentam o símbolo do Divino Espírito Santo. De um lado do altar, a imagem do Divino, do outro, a imagem de Santana. Em 2005 e 2006, usaram flores naturais como enfeite; bem diferente de dois anos anteriores em que a decoração estava bastante carregada com flores artificiais. As missas contam ainda com a presença de um coral e há uma área reservada de quatro fileiras de bancos na frente e no meio da igreja para os convidados especiais, chamados de "padrinhos". Para sentar nesses lugares, os padrinhos precisam usar um broche do divino com uma pombinha dourada no peito. Na porta da igreja ficam as "divinetes", recepcionando as pessoas que entram. Além disso, um grupo de fotógrafos e cinegrafistas espera o início da missa e a entrada das autoridades para registrar a presença deles na igreja e publicar nos jornais do dia seguinte.

Na homilia da primeira missa do ano de 2005, o bispo dirigiu-se às autoridades (prefeito, vereadores, festeiro, capitão do mastro e patrocinadores da festa) e disse que o culto a Deus é a verdadeira religião e que somente um sacerdote pode celebrar uma missa: se uma outra pessoa fizer, o faz indevidamente. No final da missa, o festeiro subiu no altar para agradecer e disse que naquela tarde tinha 
estado na Santa Casa e que levara a luz do Divino Espírito Santo aos enfermos, o que o emocionou muito. Pediu também para que as pessoas fossem à quermesse como um ato de caridade. No encerramento da missa, o bispo, que é o único moderador da liturgia, segundo suas próprias palavras, chamou todos os devotos que portavam bandeiras para ficar no corredor central da igreja e fez uma referência especial ao sensitivo dizendo que é preciso ver a fé. Segundo o bispo, “ouvir falar é uma coisa, mas a gente só começa a viver a festa quando vemos sua beleza". Pediu para que todos que estavam com bandeiras saíssem juntos com as autoridades e o clero.

As missas da novena são aparentemente comuns, seguem um padrão litúrgico prescrito conforme relatado acima. A organização das missas a cada noite é de responsabilidade das comunidades, de um conjunto de paróquias, de pastorais ou de grupos eclesiásticos. De certa forma, todos os grupos presentes na festa querem estar representados na novena e preparam uma missa. As missas em geral são parecidas e compostas com grupos de música. Mas percebe-se que há uma concorrência entre os grupos para saber qual missa é mais espetacular.

Os sacerdotes que presidem as missas representam suas respectivas paróquias e fazem homilias normalmente falando sobre a importância da palavra de Deus como revelação e do Espírito Santo como transformação. A tradição é evocada como conviç̧ão dos devotos pela fé no Espírito Santo e não apenas como continuismo de coisas do passado. Procuram ressaltar o trabalho das rezadeiras que têm um papel importante junto à igreja na tarefa de evangelizar.

Na luta simbólica, as missas não são tão semelhantes quanto parecem ser. Abaixo, apresentamos dois exemplos emblemáticos daquilo que chamamos de missa-espetáculo: a missa afro e a missa carismática como formas simétricas e opostas de tratar a polifonia dos símbolos encontrada na festa. 
MISSA AFRO-BRASILEIRA A fila do lado de fora não indicava o que aconteceria no interior da igreja. Concentrados na porta, o festeiro, os padrinhos e os convidados, em sua maioria brancos; dentro da igreja, preparando a missa, os negros. Conforme tinha sido anunciado no folheto da "programação religiosa", este seria o dia da missa afro-brasileira, organizada pelas paróquias de Santa Isabel, Biritiba Mirim e Nossa Senhora do Socorro de Mogi das Cruzes. Na abertura, berimbaus e tambores anunciavam a entrada do festeiro ao som da música Bandeira do Divino. Num primeiro momento, o olhar das pessoas era de curiosidade. $\mathrm{O}$ ano de 2006 foi a terceira experiência de uma missa toda preparada pela pastoral afrobrasileira com uma grande presença de negros na igreja como nunca houve.

Os sacerdotes, todos negros, entraram acompanhados de membros das comunidades que representavam, levando à frente uma espécie de prato de barro com o incenso de alecrim ao som de batidas de atabaques e berimbaus. Todos os ritos foram entoados em ritmos africanos. O "glória" - momento em que se leva a bíblia (evangelho) até o altar - foi acompanhado de sete tochas de fogo ao som do batuque. Os "salmos" e a "aclamação ao evangelho" também cantados nos ritmos dos tambores e das palmas. O sacerdote que presidia a missa, substituía o tradicional "vós" por "vocês". Nos bastidores da igreja, havia toda uma organização de pessoas encarregadas de cuidar do movimento entre um rito e outro: o trabalho nos bastidores consistia em observar as entradas e saídas, a abertura das portas na hora exata, de preparar as pessoas que levariam algo até o altar ou de encenar alguma dança etc, enfim, tudo parecia um grande teatro.

Na homilia, o padre leu um pequeno texto e agradeceu o festeiro, as autoridades e as comunidades eclesiásticas presentes. Comentou que no ano anterior houve uma tentativa de organizar uma missa afro, mas esta foi feita às pressas. Porém, dessa vez, a promessa tinha sido realizada e a missa ocorreu de forma oficial. O padre lembrou que até os bois e cavalos são lembrados na festa do Divino com a entrada dos palmitos e por que o povo afro-descendente não seria. $\mathrm{O}$ padre lembrou do estado de pobreza em que os negros vivem do ponto de vista político, histórico e cultural, mas que o Espírito Santo veio para não deixar o 
oprimido morrer nas mãos do opressor. Para ele, a linguagem do Espírito Santo é de amor e paz entre as etnias e culturas (discurso antropologizado) e que a unidade se faz na diversidade (lema da igreja católica). No final, fez uma oração e foi muito aplaudido.

No momento do "ofertório", dezenas de cestos de frutas e pães foram levadas até o altar numa coreografia musicada. Além disso, a imagem de Martin Luther King foi invocada em lembrança aos mortos. Muitas músicas evocavam a memória de Zumbi dos Palmares como a música Zumbi: Ei, ei, Zumbi! Zumbi Ganga meu Rei / Você não morreu, você está em mim. / Ei Zumbi, seu povo não esqueceu / A luta que você deixou pra prosseguir / Ei Zumbi, os novos quilombos com seus quilombolas, lutam pra resistir. / Ei Zumbi, seu sangue semeou coragem em nossa gente que luta com fervor / Ei Zumbi, a luta é a mesma, mudou só o cenário, a roupa e a cor. / Ei Zumbi, nossa terra é fértil, outros como você também tombaram ao chão / Ei Zumbi, e muito tombarão enquanto houver luta pela libertação. Essa música foi cantada no final da missa, mas outras foram cantadas durante a missa e traziam imagens da época da escravidão, da luta, da resistência, de traços da cultura afro-brasileira como o tambor, o atabaque, o afoxé, o homem nordestino, a capoeira, o índio, Canudos, Palmares etc. Destaco algumas passagens que ilustram melhor essas imagens. No canto de entrada: Nosso povo sofrido em ti se alegra / Nossos braços cansados pro céu se elevam. I Soa o tambor... de couro e de madeira / É na palma da mão e no gingado, na cantiga e na fé / Deus seja louvado. / Salve, salve nosso Deus / Abençoa meu Pai, somos filhos Teus / Em toda raça e toda cor / Coração bate forte como o tambor / Berimbau, atabaque e afoxé / Olodum, capoeira, irmãos na fé. Na entrada da "palavra", uma música chamada Fazei Ressoar dizia: Na cultura, na história, vamos expressar / Levando a palavra de Deus em todo lugar, vamos lá I Na cultura popular vamos catequizar / Celebrando fé e vida em todo lugar, vamos lá / Com negro e índio vamos louvar / E com toda a comunidade vamos festejar, vamos lá / Com o atabaque e com o tambor, vamos celebrar / A palavra de Deus em todo lugar, vamos lá. Nas oferendas, a música falava das mãos que produzem os frutos e do trabalho com a terra: A fé do homem nordestino que busca um destino, um pedaço de chão / A luta do povo oprimido que abre caminho, transforma a nação / ô ô ô ô, recebe Senhor. / Retalhos da nossa história, 
bonitas vitórias que o povo tem: Palmares, Canudos, Cabanos são lutas de ontem e de hoje também / ô ô ô ô, recebe Senhor. Uma outra música interessante se destacou no meio da liturgia, chamado de "momento mariana", Senhora Negra: Senhora Negra, Yá querida / Soberana quilombola, Mãe de Deus Aparecida. / Preta, pobre, Maria Mãe Yayá / Fé em Deus Nosso Pai vem ensinar. / Com seu filho Jesus vamos seguir / Seu quilombo Oxalá vai ressurgir. / Padroeira dos negros do Brasil / Olorum nosso Deus nos preferiu. / Na partilha do amor e do axé / Companheira, guerreira, mãe, mulher. I Irmã negra na luta e na cor / Peregrina, menina, yâ. / No seu canto alegria dos meninos anuncia feliz: nós já vencemos.

Curiosamente, as pessoas que estavam na igreja e no início apenas observavam, ao longo da missa ficaram empolgadas e batiam palmas. No final da missa, o festeiro subiu no altar, agradeceu os sacerdotes e disse que jamais esqueceria as comunidades afro-descendentes. No final do discurso, o casal de festeiros abraçou os padres. Ainda no clima de discurso, um padre tomou a palavra e falou da importância da celebração eucarística do jeito afro, pois nesse tipo de apresentação é possível ver a beleza que Deus criou em diversos povos. No encerramento, depois de quase duas horas de missa, uma imagem de Nossa Senhora Aparecida, uma bandeira do Espírito Santo, dançarinos e um homem com algemas soltas nos pulsos foram levados até o altar. Ao chegar no altar, a imagem de Nossa Senhora Aparecida foi erguida e muito aplaudida.

Como mediação entre a missa afro e a missa carismática (que fecharia o ciclo da novena), houve uma missa cuja data coincidira com o dia de Nossa Senhora de Fátima. O frei que presidiu a celebração também lembrou que 13 de maio era o dia da Libertação dos Escravos, mas que no Brasil ainda havia 25 mil trabalhadores escravos. A homilia do sacerdote foi bastante provocativa no que concerne à fé cristã. A pergunta do frei foi: "tu me amas?" se referindo ao diálogo entre Jesus e Pedro. 
MISSA CARISMÁTICA No momento em que as pessoas entravam na igreja era possível ver um grupo de jovens reunidos na porta vestidos de anjinhos e segurando tochas. Esse grupo conduziu a imagem da Nossa Senhora da Conceição até o altar, quando foi erguida e fervorosamente aplaudida. O padre que presidiu a missa pertence à Renovação Carismática e inclusive já gravou alguns CDs ao estilo do padre Marcelo Rossi. A missa era toda cantada; na sua maior parte pelo próprio padre. A igreja estava completamente lotada; certamente o maior público dos nove dias de novena. A ênfase do padre era extremamente emocional, muito agito, músicas altas, mãos aos altos, as pessoas em êxtase. Um espetáculo catártico que, por vezes, causava ruídos nos auto-falantes da igreja.

A homilia do sacerdote foi meio falada, meio cantada com fundo musical. O padre insistia que era preciso experimentar o Espírito Santo e fortalecer o tripé que sustenta a festa: família, fé e caridade. O discurso contundente sobre ser cristão explicava o significado das palavras que formam esse tripé. A família tem o papel de incentivar a participação dos pais junto com os filhos nas missas. Sobre a fé, o mundo e a igreja estão carentes de homens e mulheres de fé. A caridade foi traduzida como amor, misericórdia, justiça e paz. A homilia do padre foi ao modo de uma pregação pentecostal. Ele ainda disse que os dons só têm sentido quando colocados a serviço dos outros. A festa de Pentecostes é a festa da igreja de Jesus e pressupõe coesão e louvação. O Pentecostes seria o contrário da Babilônia, onde ninguém entendia a língua do outro, pois Pentecostes é comunicação. Na hora do “ofertório", anjinhos levaram pães, uva, flores, os cálices (vinho e água) e o corpo de Cristo. Os ofertórios são curiosos, há sempre um pão decorado com galhos de trigo e uva enfeitando os cestos levados ao altar.

No final, anjinhos entraram na igreja vestindo roupas douradas com balões vermelhos e corações com os sete dons escritos. O público aplaudia tudo. A missa só terminou depois de mais de duas horas de celebração.

Embora todas as missas possam parecer iguais por seguirem a mesma estrutura litúrgica e ritos prescritos com desenvolvimento pré-determinado pela cúria: ritos iniciais, leituras, proclamação do evangelho, eucaristia, ofertório, 
comunhão e ritos finais, há modulações realizadas a partir de brechas que surgem no interior da própria liturgia como na entrada, no ofertório, nas músicas que compõem a missa e, principalmente, nas homilias feitas pelos sacerdotes. Nesses momentos específicos, podemos ter algumas surpresas carregadas de tensões e contradições que ocorrem geralmente para solucionar algum ruído.

Só um detalhe: Nossa Senhora Aparecida é uma imagem de Nossa Senhora da Conceição escurecida pelo limbo do rio Paraíba. A relação entre as duas imagens pode ser representada pela seguinte álgebra: Aparecida : missa afro :: Conceição : missa carismática. Os símbolos, segundo a discussão Victor Turner acerca do culto a Nossa Senhora de Guadalupe no México (1974a), convergem para o imperativo da ordem, são usados para resolver tensões. Ao falar em luta simbólica, os olhos voltam-se para o não-resolvido dos símbolos.

PASSEATA DAS BANDEIRAS Depois das missas, geralmente a partir das $21 \mathrm{~h}$, ocorreram as passeatas das bandeiras, uma interessante procissão liminar, localizada supostamente às margens da programação da festa, que visita durante dez noites as casas de alguns devotos ou outro lugar pré-determinado. Dizem que receber a visita da passeata das bandeiras é como receber o próprio divino em casa. São visitadas, normalmente, as casas de ex-festeiros e de pessoas doentes e idosas que não podem mais acompanhar a festa pessoalmente. Há, também, visitas a uma pequena capela e a estabelecimentos comerciais como uma emissora de televisão, um jornal e uma universidade.

Os caminhos percorridos a pé têm formato semelhante ao da alvorada, ou seja, à frente vão o lanterneiro, o festeiro, o capitão do mastro, a folia do divino, seguidos pelos devotos que caminham rezando e cantando pelas ruas do centro da cidade. Em duas ocasiões, nas visitas ao canal de TV e à universidade, foram usados ônibus para transportar as pessoas até os locais de visita, partindo da catedral e a ela retornando. Assim como as alvoradas, as passeatas costumam passar na frente de 
lugares específicos como a Santa Casa, a delegacia, a prefeitura etc. Às vezes, mais de um lugar é visitado numa mesma noite.

Quando o cortejo chega à casa de destino, o festeiro e o capitão do mastro entregam as bandeiras para os moradores, assim como a coroa e o cetro, que provisoriamente ficam junto ao altar do divino. Nas confortáveis casas visitadas, a folia do divino chega para abençoar a morada, a família e trazer alegria e saúde, conforme dizem os versos das músicas (ver anexo). As pessoas esperam a visita das bandeiras, preparam as casas com um altar na sala e acendem velas. Dependendo das condições financeiras de cada família, alguns altares parecem subimpérios e uns são mais enfeitados que outros, mas sempre contam com a imagem do Divino, com bandeira, com fitas vermelhas e um espaço na base reservado para a coroa e o cetro. Antes de sair da casa, as pessoas se encaminham até ao altar, beijam a bandeira, as fitas e tocam no cetro e na coroa.

É incrível como o festeiro, em especial sua bandeira, coroa e o cetro ficam envolvidos por um poder mágico durante os dez dias de festa, pois as pessoas estão sempre perto acompanhando, tocando e beijando. Em mais de uma ocasião nas passeatas das bandeiras, uma senhora pediu para cantar uma música em latim em forma de oração chamada Ave Maria de Gounod ${ }^{17}$, como demonstração de uma dívida de misericórdia para com um ex-festeiro que a socorreu de um acidente e a acompanhou na Santa Casa - fato que ela nunca esqueceu.

Mas não só casas luxuosas foram visitadas, houve algumas casas mais simples e pequenas em que não cabiam todas as pessoas, deixando a maioria do lado de fora. Pobre ou não, depois das orações, o dono da casa serve um lanche geralmente composto por café preto, pão com manteiga, sanduíches, batida de coco, pão com patê de presunto, pão com carne, pão com mortadela, bolo, chá, chocolate quente e sucos etc.

No final, a folia faz os agradecimentos e a procissão retorna ao império geralmente por volta das $22 \mathrm{~h} 30 \mathrm{~min}$.

\footnotetext{
${ }^{17}$ Ave Maria / Gratia plena / Dominus tecum / Benedicta tu in mulieribus / Et benedictus fructus / Ventris tui Jesus / Sancta Maria (Mater Dei) / Maria ora pro nobis / Peccatoribus nunc / Et in hora mortis nostrae / Ave Maria.
} 
Num movimento que vai do liminar ou liminóide (Turner, 1982) em que elementos marginais e ambíguos são apropriados e transformados em produtos de consumo, localizamos algumas passeatas das bandeiras que escaparam de sua condição liminar e foram transformadas em gênero de entretenimento por instituições ligadas à comunicação e ao conhecimento na cidade. Separamos aqui três momentos: na TV, no jornal e na universidade.

NA TV Dois ônibus lotados levaram a folia do divino, os lanterneiros, o festeiro e capitão do mastro, juntamente com os devotos, para o canal de televisão local afiliado à Rede Globo, a TV Diário, do mesmo grupo que detém um jornal na cidade, O Diário de Mogi. Os ônibus levaram cerca de vinte e cinco minutos para chegar nas dependências da TV. No interior da emissora, havia um subimpério montado. Ali a folia tocou como se estivesse na casa de alguém. Após a prece, o festeiro tomou a palavra e agradeceu a todos através do microfone. Juntos rezaram a oração ao Divino Espírito Santo, um Pai-Nosso e cantaram parabéns à emissora que completava cinco anos de existência na cidade. O diretor da emissora, um jornalista do Rio de Janeiro, agradeceu aos devotos e disse estar emocionado com a presença deles ali. Falou sobre a importância da festa para o canal e convidou a todos para participar do café, que consistiu na distribuição de sanduíches e refrigerante.

NO JORNAL A passeata chegou ao jornal O Diário de Mogi após dez minutos de caminhada. O dono do jornal recebeu a folia e o festeiro. Após breves discursos e rezas, foram servidos café preto e pão com mortadela 
NA UNIVERSIDADE A passeata das bandeiras esteve na Universidade Mogi das Cruzes (UMC) conduzindo novamente os devotos de ônibus. Ao chegar à universidade, havia uma superprodução com direito a canhão de luz, decoração na fachada do prédio e um coral de jovens universitários com violões cantando a Bandeira do Divino. Algumas pessoas comentavam meio contrariadas que aquilo tudo descaracterizava a festa. Na entrada do prédio, havia arcos decorados com bandeiras, pombas e luzes. Da janela das salas de aula, os alunos observavam com olhares curiosos. O subimpério estava montado no prédio da faculdade de biomédicas. O subimpério, na verdade, era um palco com microfones e caixas de som. Nele subiram o festeiro, o capitão do mastro, o reitor e esposa e a pró-reitora com marido e filhos. O tom era extremamente oficialesco, com protocolo a ser cumprido e tudo. $\mathrm{O}$ pátio da universidade estava lotado. $\mathrm{O}$ reitor fez um discurso meio acadêmico, meio religioso. Depois o festeiro falou e agradeceu

Havia microfones para todos falarem, menos para a folia do divino, que ficou ali na platéia e de longe cantou sua prece. Depois da folia, um padre foi chamado, fez uma oração, rezou um Pai-Nosso, uma Ave-Maria, leu o evangelho e abençoou a todos com água benta. No final, foi servido um lanche simples com chocolate quente e pão com manteiga.

ÚLTIMA PASSEATA DAS BANDEIRAS Após longas jornadas de caminhada, na última passeata das bandeiras, os membros da folia do divino e os poucos devotos que restavam estavam exaustos. O esgotamento físico era visível, as pessoas estavam com olhos vermelhos e com sono. Mesmo reclamando de dores nos joelhos, nas pernas e nas costas, estavam todos ali firmes, persistentes e seguros na devoção. Às 22h30min, a passeata retornou ao império cantando o Calix Bento para encerrar as passeatas noturnas.

Por ser sábado à noite, o centro da cidade estava vazio. Ao chegarem no império guardaram as lanternas, o festeiro e o capitão do mastro colocaram as 
bandeiras ao lado do oratório e, acompanhada por meia dúzia de pessoas, a folia tocou a música de encerramento: “Nóis cheguemo no império, nessa hora abençoada".

\section{A RELAÇÃO ENTRE PEDIDOS E A GRAÇAS ALCANÇADAS}

Pedir para um devoto falar de sua devoção ou explicá-la é uma das tarefas mais difíceis encontradas na pesquisa de campo. Eles começam a falar e logo se emocionam. Não há um só caso entre as pessoas presentes nas alvoradas, nas passeatas, assistindo às missas, participando da procissão de Pentecostes ou mesmo da entrada dos palmitos que não tenha uma relação entre pedidos e graças alcançadas com o Divino Espírito Santo. Algumas estão ali fazendo pedidos, outras pagando. Os pagamentos dos pedidos são feitos por meio de gestos de devoção e de fidelidade ao Divino Espírito Santo ao longo de toda a vida. Ao observar os nós dados nas fitas das bandeiras dos devotos, percebemos a quantidade de pedidos feitos, de graças alcançadas e de pagamentos retribuídos. A fita na bandeira não é apenas um adorno, mas uma maneira de assegurar os pedidos através do nó atado.

A relação entre pedidos e graças alcançadas opera na lógica da troca ao modo do "dar, receber, retribuir" que não se observa empiricamente, mas se percebe em diálogo com outros elementos não necessariamente presentes na relação, dados pelo "pensamento simbólico", como diria Lévi-Strauss (1997). Essa troca estabelece um vínculo entre os devotos e o Espírito Santo, mas também um vínculo social entre as pessoas como um "fato social total" que coloca em movimento o conjunto de relações de uma sociedade e de suas instituições de modo simbólico assegurando, assim, uma realidade social integradora e relacional.

Os pedidos são geralmente feitos para atender necessidades pessoais ou problemas na família, pede-se sabedoria, iluminação, força e coragem para enfrentar 
os perigos da vida. As graças são alcançadas de imediato, ao longo do tempo ou após um certo tempo. Percebemos que há, basicamente, dois tipos de pedidos, divididos em duas categorias: no primeiro grupo estão os pedidos feitos para os outros, ou seja, para parentes e amigos; no segundo grupo, pedidos para os próprios devotos. Além disso, podemos dizer que há pedidos que estão num plano mais cotidiano e imediato (falta de dinheiro, desemprego, briga e discórdia na família) e outros pedidos mais gerais e abrangentes (cura de doença, casamento, gravidez e proteção contra riscos a segurança pessoal ou familiar). Os agradecimentos são feitos através de atos de devoção, de caridade, em participação e/ou voluntarismo na festa (trabalhar na casa da festa, em alguma barraca da quermesse, no café da alvorada etc), e, principalmente, indo às missas, às alvoradas, às passeatas etc.

O pedido, a graça alcançada e o pagamento estão presentes na vida dos devotos e são decisivos na relação que esses estabelecem com o Divino Espírito Santo. Para Pierre Sanchis, “a promessa [o pedido] é a relação estabelecida entre a condição humana concreta e um envólucro de santidade que a rodeia. Faz parte de uma visão do mundo dentro da qual constitui um modo de comunicação essencial. Por isso mesmo ela aproxima-se do sacrifício, ao mesmo tempo que se insere no quadro de uma economia, a da troca" (1992, p.47). Durante o trabalho de campo, ouvimos muitos depoimentos que relatam essa relação entre o humano e o divino. Essas pessoas são movidas e se dizem constantemente surpreendidas pelo Espírito Santo. Vejamos algumas dessas narrativas.

Uma rezadeira nos disse que as pessoas já nascem na festa do Divino. Desde menina ela achava que a festa era somente as missas e as procissões, mas nos últimos vinte anos começou a participar de modo mais intenso e percebeu que para atender sua "ansiedade religiosa" precisava de um envolvimento maior. Para ela, era preciso encontrar o Criador através de uma "comunidade". Assim, com a turma da festa, ela se realizou como devota. Para a rezadeira, o Divino Espírito Santo é o começo de tudo, sem ele não dá para fazer nada, pois o Espírito Santo está presente em todas as religiões. Já a festa do Divino Espírito Santo é a realização de tudo que foi vivido em termos de Deus na Terra. É o momento de expressar sentimentos, 
sobretudo quando se atinge uma graça, pois ao fazer um pedido o devoto adquire forças para transformar o estado atual das coisas.

É interessante o modo como a rezadeira entende a bandeira que carrega. Para ela, a bandeira é como se fosse uma bíblia. Explicação: o homem não nasceu lendo nem escrevendo, ele nasceu seguindo "símbolos". Esses símbolos vêm exatamente da bandeira. Na bandeira dela estão impressas mensagens recebidas do divino. Essas mensagens dizem sobre imagens inexplicáveis. Uma dessas imagens era de estrelas: ela caminhava no meio de uma floresta e recebeu uma mensagem em espécie de uma grande estrela que caía do céu e trazia outras estrelinhas. Até hoje tenta decifrar essa mensagem que está fixada em sua bandeira. Para ela, há uma equivalência entre o poder da bandeira e o da bíblia, ou seja, segurar a bíblia e segurar a bandeira é a mesma coisa, significa que a pessoa está com Deus, só que na bíblia está escrito e na bandeira estão os símbolos (ou as imagens). Ao olhar para a bandeira, é possível visualizar o Espírito Santo, os dons e o que ela chama de símbolos.

Sobre a relação entre pedidos e graças alcançadas, a rezadeira conta que uma vez a cunhada estava sofrendo de dores muito fortes e os médicos não descobriam as causas. Então ela levou a bandeira para casa da cunhada, começou a rezar e viu a pomba do Divino Espírito Santo se transformar num corvo que pousou no chão e começou a cavar a terra. Ao ver aquela cena, a rezadeira disse que se manteve firme na oração. No final, o corvo pousou de volta na bandeira e se transformou novamente em pomba. Ela voltou para casa tentando decifrar o que seria aquilo. Tempos depois, descobriu que a cunhada sofria de hérnia de disco e precisava ser operada. Momentos antes de ser internada, ela disse à cunhada para ir tranqüila ao hospital porque o Divino Espírito Santo já tinha feito a operação. Para ela, na hora em que o corvo cavou a terra usando as garras e o bico, na verdade, estava arrancando a carne podre da doença. Um outro detalhe: o médico disse que ela não andaria, mas, pela força do Divino Espírito Santo, segundo a rezadeira, a cunhada está andando normalmente. 
Outra história intrigante: fazia três anos que ela andava com a mesma bandeira nas visitas às casas. Numa determinada casa, em que havia duas pessoas deficientes, a bandeira se dividiu em duas partes. Uma parte ficou perto da rezadeira, a outra foi usada para percorrer a casa. Quando terminou a reza, as duas partes se encaixaram novamente. Ela ainda não descobriu por que isso aconteceu. De qualquer modo, para a rezadeira não resta dúvida de que a sua bandeira é mágica, tem poder de comunicação e de transformação.

Uma outra rezadeira, que também é voluntária no "café do divino", já presenciou diversos casos em que as pessoas receberam graças. Um dos primeiros casos foi de uma pessoa que trabalhava no fórum e estava sendo prejudicada por uma colega de trabalho. A rezadeira pediu na oração para que essa pessoa não fosse mais prejudicada e a pessoa inimiga acabou sendo afastada do trabalho. Num segundo caso, uma amiga teve a pomba do divino quebrada também por uma colega de trabalho e pedia todo ano durante a festa para mudar de emprego, colocando os pedidos nas caixinhas das rezadeiras. No terceiro ano, ela conseguiu mudar de emprego. No terceiro caso, uma mulher que recebia a rezadeira pediu para levar a bandeira na casa da neta que estava grávida e com problemas nos seios. A rezadeira contou que foi como tirar o problema com a mão; a jovem teve o bebê e pôde amamentar normalmente. O filho dessa mesma mulher tinha problemas com drogas e também o superou por causa do Divino Espírito Santo. Num outro caso, a mãe de uma colega de trabalho da rezadeira estava muito doente e foi até sua casa pedir um pedaço da fita da bandeira do divino para colocar no café. A mãe dessa colega tomou o café e ficou curada.

Para a rezadeira, o divino tem o poder de transformar a vida das pessoas, basta ter fé. Ela diz que o Espírito Santo é o nosso criador, nos redimiu, nos santificou e tem o poder de indicar os caminhos por toda a vida. O divino é capaz de transformar até a vida dos que estão presos. Ela conta que antigamente ia-se à cadeia rezar. Faziam uma oração igual fazem no hospital e nas casas. Hoje, o delegado não permite mais. 
Para ela, ser rezadeira é uma graça de Deus, é uma missão. Levar a palavra de Deus para as casas das pessoas é a maior das graças, uma coisa muito sublime e muito séria. Ela tem o hábito de conversar com o divino, mas também com Nossa Senhora e com todos os santos que estão na sua casa. Para tudo que faz, ela pede o auxílio do Divino Espírito Santo e de Nossa Senhora.

Para um devoto, a alvorada é a melhor parte da festa do Divino porque esse é o momento que exige mais sacrifício das pessoas. Para ele, a cidade muda durante a festa. O espírito de voluntariado aflora nos dias de festa, porque todos querem ajudar. Não há outro momento na vida de Mogi das Cruzes que se compare ao período da festa do Divino. Há pessoas que esperam o ano inteiro para chegar o momento da festa. Há inclusive a presença de pessoas de outras religiões que ajudam na festa, sobretudo espíritas e umbandistas. Para ele, a crença no Espírito Santo, uma das três pessoas da Santíssima Trindade, é a verdadeira devoção. O Espírito Santo é a alma da igreja católica que apareceu em forma de línguas de fogo sobre os apóstolos.

Ele revelou que a sua devoção para com o Espírito Santo é um ato de gratidão pela saúde do seu neto. Segundo conta, o Espírito Santo salvou a vida da criança nascida prematuramente com seis meses, ficando quatro meses na UTI. O bebê teve parada cardíaca ao nascer, mas sobreviveu. Para ele, o fato de o neto ter sobrevivido e hoje viver sem seqüelas com treze anos de idade foi uma graça recebida pelo Divino Espírito Santo. Todos têm uma ligação de pedidos, graças alcançadas e pagamentos. Isso é quase unânime, disse o devoto.

O mestre de um dos grupos de congada foi agraciado pelo Divino Espírito Santo em 1975, quando ficou quinze dias internado e esteve em coma durante três dias após ter sofrido um atropelamento. Disse que, durante o coma, sonhou com um homem negro que foi até o seu leito dizer que não morreria porque alguém mais forte não permitiria. Ele conversou com esse homem que o tranqüilizou ao dizer tais palavras. Logo após essa visita, ele acordou com a certeza de que tinha conversado com São Benedito e que a pessoa mais forte era o Divino Espírito Santo. Desde então é um devoto fiel de São Benedito e do divino. 
Ele diz ser muito católico e muito devoto, pois cresceu rezando e indo à igreja. Para o mestre da congada, vale a pena ter um santo de devoção, pois assim já alcançou diversas graças e também presenciou outras pessoas recebendo. Contou uma história sobre o filho de uma amiga que não encontrava trabalho em nenhum lugar. Ele perguntou ao rapaz se acreditava em Deus, o rapaz disse que sim, mas que não adiantava porque já tinha mandado currículo para todos os lugares e ninguém o chamava. $\mathrm{O}$ mestre então disse que tinha um santo que auxilia as famílias e poderia ajudar a mulher e seu filho, os Santos Reis. Então, a mãe do rapaz pediu para eles irem tocar na casa com o grupo de folia de reis ${ }^{18}$. Ao chegar na casa, a mulher só tinha um quilo de farinha de trigo, um quilo de açúcar e dois ovos. Mesmo assim, ela fez um bolo, deu para a turma dizendo que no próximo mês as coisas seriam diferentes. A folia tocou uma música em agradecimento dizendo que aquela pessoa seria recompensada com grande rapidez nesse mesmo mês. Dois dias depois, a mulher reaparece na casa do mestre emocionada e dizendo que seu filho havia arrumado um emprego e gostaria que a folia visitasse a casa dela todo ano. Ela tinha dado os últimos alimentos para eles, mas agora que o filho iria ganhar bem, foram ao mercado e compraram muita comida. Ela queria retribuir ao mestre com um saco de arroz, mas a esposa do mestre disse para ela entregar o pacote à primeira pessoa que encontrasse na rua. Na mesma hora passou uma outra pessoa pedindo ajuda e ela entregou o arroz. Para o mestre, essa foi uma das maiores histórias que ele já presenciou.

Segundo um outro devoto, com quem conversamos durante o café da alvorada, a devoção é muito grande principalmente quando se nasce naquela religião. A relação entre pedidos e graças alcançadas funciona na vida das pessoas e ela teve provas de muitos que hoje acompanham o levantamento do mastro, tomam o licor rosa-sol, fazem pedidos, são atendidos e depois voltam para agradecer. Para ela, até pessoas que não se envolviam muito com a festa levam prendas para o império como agradecimento de graças alcançadas. Uma maneira de agradecer é participar em algum momento da festa. Muitas pessoas vêm à alvorada para pagar

${ }^{18}$ Além do grupo de congada, o mestre também tem um grupo de folia de Reis. 
promessa pela graça alcançada. Para ela, nas alvoradas estão presentes os verdadeiros devotos que realizam um grande sacrifício ao levantar de madrugada para estar ali. Na passeata das bandeiras, a pessoa está disponível durante o dia, vai assistir à missa e depois acompanha a passeata como uma continuidade do dia. Mas levantar com chuva, com frio, com neblina e sair de casa às 4 h da manhã para fazer uma caminhada é realmente um ato de devoção, uma espécie de dever. De fato, podemos observar que os devotos se sentem obrigados, ou pelo menos socialmente constrangidos, a estarem presentes em, pelo menos, uma alvorada.

Para outros devotos, o calendário católico pontuado pelas festas de santo e de devoção popular faz parte da vida das pessoas. Em conversa com a mulher do capitão do mastro, ela contou que um dia estava com a mãe no hospital e precisava falar com o médico. Como tinha de ir embora, foi até o elevador para sair, mas o elevador não chegava. Então ela resolveu descer pela escada e acabou encontrando o médico. Aí ela disse: "foi o Espírito Santo que me ajudou". Para ela, o Espírito Santo é essa força. Ela contou que ficava emocionada ao ver senhoras idosas sob frio intenso caminhando nas alvoradas com pouca roupa. Como mulher do capitão do mastro, ouviu muitos relatos de graças alcançadas: um filho que sofreu acidente e se recuperou, uma moça que conseguiu engravidar, pedidos de emprego atendidos, saúde, proteção e até o pedido de um menino que queria um vídeo game.

Somando a devoção com a organização da festa por meio de uma associação, temos a configuração de uma "festa total". Lembrando novamente de Marcel Mauss, devemos estudar os fenômenos sociais totais. A festa como fato social total possui um valor sociológico geral para o grupo. Isso significa dizer, nas próprias palavras de Mauss, que "põem em movimento, em certos casos, a totalidade da sociedade e de suas instituições e, em outros casos, somente um grande número de instituições, em particular quando essas trocas e contratos dizem respeito de preferência ao indivíduo" (1974, p.179). Os fatos sociais totais exprimem todas as espécies de instituições religiosas, jurídicas e morais que representam a sociedade. O fato social não é total somente por ser observado como um todo, é total, sobretudo, por ser 
uma categoria integrada que compreende sistemas de troca de bens, serviços e símbolos da cultura e da vida social.

\section{RUÍDOS E DESARRANJOS}

Num texto de apresentação ao artigo de Victor Turner sobre a antropologia da experiência, John Dawsey diz que o autor aponta para um "desvio" metodológico cuja “atenção do antropólogo volta-se aos ruídos e elementos estruturalmente arredios" (2005a, p.164). A idéia de Turner é localizar um lugar onde seja possível detectar os elementos não-óbvios das relações sociais. Nos últimos parágrafos desse capítulo, que tratou do poder transformador do Divino Espírito Santo em suas diversas dimensões - crença na eficácia mágica dos seus ritos, experiência de ser devoto, relação entre pedidos e graças alcançadas, etc. -, apresentamos alguns momentos que escapam da ordem regular prevista na programação oficial da festa do Divino de Mogi das Cruzes e aparecem às suas margens como imagens caóticas carregadas de tensão. A idéia aqui não é mostrar um "final feliz", um "desfecho harmônico", mas focar alguns elementos estruturalmente arredios que compõem a realidade social da festa. Acima, foram apresentadas as manifestações do sensível, mas não se pode deixar de fora as contradições e os ruídos desse sensível.

Do lado de fora da igreja, fora das missas, nas bordas das passeatas das bandeiras e até mesmo das alvoradas (apesar do horário), encontrávamos pessoas alcoolizadas ou tidas como loucas que desconcertavam a aparente ordem vigente. Para Dawsey, essas "figura alteradas, ou mesmo grotescas, ganham preeminência. Abrem-se fendas no real, revelando o seu inacabamento. Tensões suprimidas vêm à luz. Estratos culturais e sedimentações mais fundas da vida social vêm à superfície. Assim, nos espaços liminares, se produz uma espécie de conhecimento: um abalo" (2005b, p.24). 
Nas linhas finais desse capítulo, vale recuperar algumas imagens estranhas que surgiram em forma de ruídos e desarranjaram a ordem estabelecida. Comecemos por cenas vistas nas alvoradas, depois nas missas, nas passeatas e até mesmo em outros espaços da cidade de Mogi das Cruzes.

Durante uma alvorada, tudo parecia transcorrer dentro da mais perfeita harmonia, até o momento em que o café atrasou um pouco para ser servido. Então começou um burburinho que foi aumentando com o passar do tempo: "quero café!", "êita cafezinho demorado", "olha o café!", e alguns batiam com a xícara no pequeno balcão improvisado.

O carro de som que acompanha a alvorada tinha um som bastante alto, somando com as pessoas que acompanham, o barulho realmente poderia incomodar àqueles que estavam dormindo. Em mais de uma ocasião, as pessoas acordadas olhavam a procissão passar e alguns mais irritados chegavam a reclamar e gritar: “Olha o barulho!”

Numa certa madrugada, a temperatura estava bastante agradável e acabou contribuindo para reunir muita gente na alvorada. Antes de começar a procissão, aconteceu um acidente de trânsito bem em frente às lanternas. Um carro bateu na traseira do outro e fugiu. As pessoas ficaram agitadas e, curiosas, saíram de onde estavam para ver o que tinha acontecido. Não tinha acontecido nada, apenas uma lanterna - a do carro - foi quebrada. Mas esse imprevisto serviu para que a alvorada saísse atrasada. Como havia muita gente, o lanterneiro precisou de muita habilidade para que não houvesse um tumulto ainda maior. Depois de alguns minutos, tudo voltou ao seu estado de normalidade. Num outro dia, os quinze minutos em que o trânsito ficou interrompido causou a fúria de alguns motoristas que, às $5 \mathrm{~h}$ da manhã, ficavam insistentemente buzinando até o trânsito ser liberado.

Durante as missas, era possível visualizar um sujeito alto, magro e já idoso andando de modo inquieto pela igreja com sua bandeira. Esse indivíduo é muito conhecido por todos, que o tratam como uma pessoa ingênua, simplória e tola. Essa figura estava presente em quase todos os lugares e apesar da aparente indiferença com que era tratado parecia incomodar muito as pessoas. Às vezes, andava de um 
lado para o outro auxiliando as moças da acolhida (as "divinetes") a carregar cadeiras para aqueles que chegavam por último e não podiam sentar nos bancos da igreja que já ficava lotada antes mesmo de a missa começar. Sua presença é, de fato, marcante. Ele quase não fala, está sempre calado e não consegue ficar parado num único lugar. Sua presença é certa em outros momentos da festa como as alvoradas, as passeatas, a entrada dos palmitos e a procissão de Pentecostes. A missa de que ele mais gostou foi a missa afro. Esteve o tempo todo dançando animado ao lado do altar. Quando acompanha a folia do divino até a casa de alguém, não hesita em encher a sua sacolinha com os lanches oferecidos. Durante a passeata realizada na TV, estava bastante agitado, falando e gesticulando muito até ser repreendido por algumas pessoas. Na passeata que foi até o jornal, alguns meninos de um colégio o chamaram de "lingüiça". Ele ficou enfurecido e mandou os moleques para "aquele" lugar. Numa das únicas passeatas em que caminhou à frente conversou alguma coisa com a esposa do capitão do mastro que lhe entregou o cetro por alguns minutos. Nesse dia a alvorada teve a presença do fogueteiro.

Corinthians! Gritou um sujeito aparentemente embriagado parado na rua ao ver a procissão da passeata das bandeiras passar juntamente com os fogos que espocavam no ar.

Em frente à igreja, presenciamos uma cena cômica - para não dizer trágica. $\mathrm{O}$ pipoqueiro estava brigando com uma mulher que parecia embriagada. Essa "louquinha" insistia em entrar na igreja e já havia sido retirada duas vezes por esse mesmo pipoqueiro. Na terceira investida, esse senhor a agarrou pelo colarinho e a fez se afastar aos gritos de ameaça para que ela não voltasse. Essa ainda ficou alguns minutos sentada na frente da igreja ameaçando entrar novamente, mas não o fez. $\mathrm{O}$ pipoqueiro disse para ela ir embora dali. Alguns minutos depois, a mulher (negra, mal-vestida e suja) saiu andando e, entre gargalhadas, sumiu pelas ruas do centro da cidade.

Numa certa noite, houve um conflito entre o festeiro e a folia do divino. Para os componentes da folia, o festeiro estava andando muito depressa e resolveram segurar o passo e deixar o festeiro caminhar à frente, deixando um espaço imenso 
entre os dois grupos. O povo que estava atrás da folia - em sua maioria velhos apoiou a posição dos violeiros e acompanhou os passos lentos da folia que reclamava da pressa. Nesse dia, a TV local filmava tudo para inserir no telejornal do dia seguinte. Como em um passe de mágica, nenhuma cena desse conflito foi mostrada.

Fora do espaço da festa, pelas ruas, os comentários na cidade acerca da festa do Divino eram interessantes:

- na fila do supermercado um amigo encontra o outro e diz: "Já foi no divino?" “Que divino", responde. "A quermesse?", insiste. "Não, não sei o que é isso e nem quero saber". "É, tá tão bonito... mas ouvi dizer que estavam querendo cobrar a entrada". "Eu não que preocupo com isso", disse o outro já mudando de assunto. - no restaurante: "Tô achando essa festa do Divino muito fraca este ano". Uma outra pessoa comenta: "Agora parece escola de samba, tem muita coisa". A primeira diz: “O novo bispo não quis muito enfeite esse ano" e a segunda completa "O bispo é novo, né? Achou que o povo tava esquecendo a religião". Depois segue o diálogo: "Sabia que queriam cobrar para entrar na festa?" “É?" “Dois reais... igual a festa dos japonês (sic), mas parece que o bispo proibiu". "Acho que essa festa perdeu a essência".

Evocando novamente a imagem de Victor Turner, diríamos que elementos caóticos podem surpreendentemente revitalizar o cosmos (mas nem sempre). Essas tensões apresentadas acima permitem perceber como os elementos arredios são "estruturalmente" arredios. Turner preocupa-se especialmente com esses momentos de interrupção e da capacidade do residual e das coisas não resolvidas da realidade social remeter para essa própria realidade.

Nesse capítulo apresentamos inicialmente as regularidades da devoção e encerramos com aquilo que escapa da ordem estabelecida. No próximo capítulo, discutiremos a montagem de dois cortejos que ocorrem praticamente no mesmo 
espaço, o centro da cidade de Mogi das Cruzes. É pertinente lembrar que esse espaço da cidade é restringido por uma lei municipal (n. 2.683 de 16 de agosto de 1982) que regula o uso da área e busca proteger o "patrimônio cultural e paisagístico". Trata-se de uma área de zoneamento que se localiza entre as principais igrejas da cidade. Os percursos dos cortejos não são tão longos. Basicamente partem de um ponto determinado e passam em frente à catedral de Santana, da igreja do Carmo, igreja de São Benedito e de Nossa Senhora do Rosário (hoje já destruída). 


\section{ENTRE PALMITOS E PENTECOSTES: MONTAGENS E IMAGENS}

Neste capítulo, apresentaremos alguns modos sensíveis de representação da devoção ao Divino Espírito Santo tendo como foco de discussão a análise da entrada dos palmitos e da procissão de Pentecostes. A idéia é de que há um simbolismo espacial inscrito em toda a dinâmica da festa ao modo de Clifford Geertz quando analisou o espetáculo de sacrifício de mulheres do Estado-teatro em Bali no século XIX, o Negara. As procissões têm, geralmente, uma ordem rigorosa e a capacidade de transformar o caos em cosmos através de "símbolos sensíveis imediatamente apreensíveis" (Geertz, 1980, p.132). Esses deslocamentos no espaço são uma espécie 
de desfile de figuras alegóricas que veiculam imagens não apenas de pessoas e de objetos, mas de idéias gerais e abstratas como devoção e fé que ordenam e unificam a vida social. Uma realidade plástica está presente nos ambientes dos cortejos apresentados aqui, desde a mais simples bandeira do divino na entrada dos palmitos até a procissão final e triunfal de Pentecostes.

Olhamos para esses dois cortejos como uma "coleção de palcos" que se ordenam espacialmente. A entrada dos palmitos, tal como diria Geertz, é uma expressão cuja função não é aliviar ou exacerbar as paixões sociais, mas exibi-las em meio aos gemidos inefáveis dos eixos dos carros de boi, das bandeiras, dos palmitos, dos cavalos etc. Para Geertz (1978), a briga de galos cria montagem, ou seja, junta coisas que não deveriam estar lá, assim como as coisas se juntam na entrada dos palmitos. A procissão de Pentecostes, como a afirmação ornamental do poder espiritual, exprime uma visão da realidade e, ao mesmo tempo, apresenta as condições de vida concernentes a essa realidade.

Geertz busca nas análises culturais a lógica informal da vida real. Para ele, “os cenários, os adereços, os actores, os actos realizados pelos actores, a trajectória geral de fé religiosa que esses actos descrevem -, todos estes elementos precisam de ser confrontados com o background do que afinal de contas se estava a passar. E só se pode perceber esse background na medida em que esses componentes teatrais sejam compreendidos" (1980, p.134). Para Dawsey, “a dramaturgia social de Negara evoca o 'maravilhoso', a ordem cósmica, colocando as pessoas em estado de êxtase" (1998, p.43). Claro, Geertz fala em termos de um Estado-teatro em Bali do século XIX, mas, para além disso, podemos formular nossas questões acerca desses cortejos encontrados na festa do Divino de Mogi das Cruzes.

Os percursos dos cortejos formam um quadrado onde estão localizadas quatro igrejas. As caminhadas seguem em direção à catedral de Santana, mas passam pela igreja do Carmo, pela igreja de São Benedito e pela igreja de Nossa Senhora do Rosário demolida em 1966, mas que permanece intacta na memória da cidade. Entre as três (ou quatro, como queiram) igrejas não é permitida a construção de prédios conforme lei municipal de zoneamento. 
Muitos devotos narram a seguinte história: centenas de pessoas vinham da roça e, antes de entrar na cidade, lavavam os pés no rio, calçavam os sapatos e seguiam até a igreja de Nossa Senhora do Rosário para participar da entrada dos palmitos e do levantamento do mastro. Antigamente, dizem, a cidade de Mogi das Cruzes era só o centrinho em volta da igreja de Nossa Senhora do Rosário. A igreja conhecida atualmente como catedral só foi construída na década de 1970.

\section{A ENTRADA DOS PALMITOS}

Na década de 30, precisamente no ano de 1936, o então jovem professor de sociologia da recém-formada Universidade de São Paulo Claude Lévi-Strauss e sua esposa Dina Lévi-Strauss estiveram, acompanhados de Mário de Andrade, que naquele momento dirigia o Departamento de Cultura da Prefeitura de São Paulo (1935-1937), na festa do Divino Espírito Santo de Mogi das Cruzes, observando e registrando em vídeo alguns momentos dessa festa. No ano seguinte, 1937, Mário de Andrade publicaria na Revista do Arquivo Municipal um artigo intitulado "A Entrada dos Palmitos" descrevendo esse cortejo que é realizado somente na festa de Mogi das Cruzes. O texto traz para o público paulistano revelações sobre um folclore desconhecido, apesar de ser encontrado praticamente nas portas das casas. Curiosamente, Mário de Andrade não presenciou pessoalmente o evento, pois chegou à cidade por volta do meio dia, conforme ele mesmo relata no texto, e esse evento ocorre pela manhã, a partir das nove horas. A sua ausência, porém, não altera a riqueza do texto, construído e interpretado na chave frazeriana a partir dos capítulos do Ramo de Ouro (1982) em que o antropólogo vitoriano discute as festas pagãs e o culto às árvores na Europa.

O objetivo do culto às árvores, conforme diz Frazer, era espalhar as bênçãos dos vegetais nas casas carregando-os em procissão. Segundo o autor, "em muitas partes da Europa, na primavera ou no princípio do verão, ou mesmo no dia do 
solstício de verão, era e ainda é costume ir passear nos bosques, cortar árvore e levála de volta para a aldeia, onde é erguida em meio à alegria geral. Ou então cortam-se ramos na floresta que são pregados em todas as casas. A intenção desses costumes é levar para a aldeia, e para cada casa, as benções que o espírito das árvores tem o poder de conceder" (1982, p.62). Essa citação de Frazer fez Mário de Andrade dizer o seguinte sobre a entrada dos palmitos: “A ida ao mato, a escolha da palmeirinha, o corte da árvore ou de seus ramos, o transporte festivo do vegetal ao aglomerado urbano, o seu plantio na praça ou diante das casas, ou prende-lo de qualquer forma á fachada das casas, os bois de transporte, todo êsse ritual, tudo isso que é da própria essência do culto da Máia, se acha repetido na Entrada dos Palmitos" (1937, p.54).

Para Frazer, o culto às árvores teve um importante papel na história da Europa. O autor, em seu conhecido método de inventariar ritos e costumes, traz exemplos de diversas partes do mundo. Mas o que chamou a atenção de Mário de Andrade foram as histórias de culto de árvores na Inglaterra, na Grécia, na Caríntia e em Roma, como a figueira sagrada de Rômulo que, ao murchar, causou consternação na cidade. Acredita-se, diz Frazer, que os espíritos das árvores são dotados de poderes mágicos e benéficos tanto para os que ele chama de "selvagens" como para os "civilizados". Mário de Andrade associou o culto da "árvore de maio" na Europa, momento em que um mastro era enfeitado com fitas no dia da festa da primavera, ao mastro usado na festa do Divino em Mogi das Cruzes.

A entrada dos palmitos é tida como uma particularidade da festa do Divino Espírito Santo de Mogi das Cruzes em relação a outras festas no país, por se tratar de um gigantesco cortejo de sons e cores que atravessa a cidade e é assistido por milhares de pessoas nas ruas. "Um espetáculo de fé e devoção" é o que se ouve nas ruas nos momentos que antecedem esse cortejo. Não há um modelo a ser seguido rigorosamente todos os anos. Ao longo do tempo vão surgindo alterações e novidades como, por exemplo, a recriação da figura do bandeireiro inspirado numa das pranchas de Debret que caminhava ao lado da folia do divino em busca de esmolas, conforme vimos em 2004. Ou então a presença repentina de um palhaço conhecido na cidade, o palhaço Bubu, como aconteceu no desfile de 2005. 
O CORTEJO Dizendo ao público que o espetáculo estava para começar, vinte minutos antes do início a temperatura aumentava ao som dos tambores dos grupos de congada e de moçambique que se concentravam em frente à pequena capela de Santa Cruz no alto da cidade de onde partiria o cortejo. No ano de 2004, fazia muito calor e o dia estava lindo: céu azul, sol forte. Amarrados aos postes, galhos de palmeiras representavam os palmitos. Entre as crianças e o público que aguardava, vendedores de cata-vento marcavam presença. Os soldados do Tiro de Guerra estavam perfilados à frente junto com o grupo de escoteiros da cidade. Antes deles, a Polícia Militar e uma equipe da festa, com duas picapes lotadas de panfletos, bandeirinhas e água que foram distribuídos durante o evento. Aos meninos escoteiros cabia a tarefa de distribuir as bandeirinhas para o público que estava nas calçadas. Junto deles, cinco bonecões da AMDEM (Associação Mogicruzense de Defesa do Menor) - semelhante aos mamulengos encontrados no carnaval de Olinda (PE) - que representavam os voluntários que trabalham na festa.

Os chamados grupos folclóricos estavam dispostos na seguinte ordem: em primeiro lugar, o moçambique de São Benedito e Nossa Senhora do Rosário do mestre José Tavares; em segundo lugar, o Moçambique São Benedito, Bom Jesus e Nossa Senhora do Rosário, do mestre Benedito; em terceiro lugar, a congada Santa Ifigênia, da mestre Gislaine, carregando as bandeiras da congada e do Divino Espírito Santo; em quarto lugar, fundada em 2003, a congada Batalhão Nossa Senhora Aparecida, do mestre Nêgo Otaviano; em quinto lugar, a congada Nossa Senhora do Rosário, do mestre Dico, com as bandeiras do Brasil e de São Benedito; em sexto lugar, a congada de São Benedito - Império de César, do mestre Chico Preto. Centenas de pessoas em volta observavam e tiravam fotos. Sob forte calor, os componentes dos grupos já suavam mesmo antes de começar o desfile. Um emaranhado de cores tomava conta das ruas estreitas do centro da cidade: o branco, o amarelo, o verde, o azul se misturavam com o vermelho predominante.

Em seguida vinham os grupos de Trança Fitas, "Grupo Ô de Casa" (Vila Sabrina, São Paulo) e a folia do divino da casa dos Açores de São Paulo (Vila Carrão). 
Na frente dos festeiros e capitães do mastro, um casal de crianças vestido de imperadores do divino. Junto dos festeiros, os filhos. Logo atrás, um bloco de exfesteiros escoltados pelos soldados do Tiro de Guerra, que era seguido por centenas de pessoas carregando as bandeiras do divino e pela banda Santa Cecília. Depois, um grupo de senhoras ligadas ao programa Universidade Aberta - a Integração (UNAI/UBC) da Universidade Braz Cubas, as paróquias e as escolas, cerca de dez comunidades e de dez escolas. Algumas delas homenageavam o Papa João Paulo II; outras traziam os sete dons, bandeiras e jovens cantando em coreografia. Depois seguia um grupo de familiares de Nhá Zéfa com filhos, netos, bisnetos e tataranetos.

Abrindo o cortejo dos carros de boi, a charola ${ }^{19}$ carregada de frutos e alimentos, conduzida por Dona Albertina. O segundo carro de boi trazia mudas de palmitos e crianças. Os três carros seguintes traziam crianças e o lema da festa, que em 2005 era "família, fé e caridade". Os outros carros (dezenove no total) traziam crianças e arcos enfeitados. Na charola tinha couve, milho, cebola, abóbora, melancia, banana, berinjela, cenoura, beterraba, chuchu, pinhão, caqui, limão, feijão, farinha de trigo, açúcar, fubá, mexerica, maçã, pimentão, laranja, farinha de milho, canjica, amendoim, repolho, arroz, sal, soja e manga (conforme foi possível contar). Depois da entrada dos palmitos, esses produtos geralmente são doados para uma instituição de caridade.

$\mathrm{Na}$ seqüência vieram as charretes puxadas a cavalo, cerca de 36, e os cavaleiros precedidos por uma banda montada da PM (Banda Clarins) com sete cavalos. Uma criança montada num cavalinho abriu o cortejo dos cavalos. Eram centenas de cavalos, alguns inclusive paramentados de tropeiros. Ao longo das ruas, as casas estavam enfeitadas e as pessoas jogavam pétalas de flores.

Havia toda uma parafernália tecnológica que controlava tudo para que não houvesse problemas ou falhas durante o desfile. A entrada dos palmitos tem um coordenador responsável e uma equipe que se comunica entre si através de rádios juntamente com funcionários da prefeitura e soldados da Polícia Militar.

\footnotetext{
${ }^{19}$ A charola é o principal carro da entrada dos palmitos. Charola é o mesmo que "andor" e levar algo em charola significa demonstrar apreço e devoção.
} 
No meio de toda essa organização o palhaço Bubu resolveu subir na garupa de um cavaleiro e participar do desfile. Na tradição popular medieval, conforme diz Bakhtin (2002), a presença do palhaço se constitui como imagem invertida do rei; esse seria o momento em que o povo poderia injuriá-lo.

Parados em frente à catedral os festeiros, os capitães do mastro, o prefeito, algumas autoridades, a PM e o Tiro de Guerra assistiram à seguinte montagem: 
ENTRADA DOS PALMITOS

\begin{tabular}{|c|c|}
\hline CARROS DE APOIO & 1 \\
\hline ESCOTEIROS & 2 \\
\hline BONECOS DA AMDEM & 3 \\
\hline MOÇAMBIQUE SÃO BENEDITO E NOSSA SENHORA DO ROSÁRIO & 4 \\
\hline MOÇAMBIQUE SÃO BENEDITO, BOM JESUS E NOSSA SENHORA DO ROSÁRIO & 5 \\
\hline CONGADA SANTA EFIGÊNIA & 6 \\
\hline CONGADA NOSSA SENHORA APARECIDA & 7 \\
\hline CONGADA NOSSA SENHORA DO ROSÁRIO & 8 \\
\hline CONGADA SÃO BENEDITO - IMPÉRIO DE CÉSAR & 9 \\
\hline GRUPO TRANÇA FITAS & 10 \\
\hline FOLIA DO DIVINO DA CASA DOS AÇORES & 11 \\
\hline IMPERADOR & 12 \\
\hline FESTEIRO E CAPITÃO DO MASTRO & 13 \\
\hline BANDEIRAS DO DIVINO & 14 \\
\hline EX-FESTEIROS E TIRO DE GUERRA & 15 \\
\hline CAVALEIRO (SEM CAVALO) & 16 \\
\hline BANDA SANTA CECÍLIA & 17 \\
\hline UNIVERSIDADE BRAZ CUBAS & 18 \\
\hline PARÓQUIAS E ESCOLAS & 19 \\
\hline NHÁ ZÉFA & 20 \\
\hline CARRO DE SOM & 21 \\
\hline CHAROLA & 22 \\
\hline CARROS DE BOI & 23 \\
\hline CHARRETES & 24 \\
\hline BANDA MONTADA DA PM & 25 \\
\hline CRIANÇA NO CAVALINHO & 26 \\
\hline CAVALEIROS & 27 \\
\hline POLÍCIA MILITAR & 28 \\
\hline AMBULÂNCIA & 29 \\
\hline BLOCO DE LIMPEZA & 30 \\
\hline
\end{tabular}


Após duas horas de cortejo pelas ruas da cidade, encerrou-se a entrada dos palmitos. Devotos para um lado, carros de boi para outro e cavaleiros para um outro. A multidão que se aglomerava nas calçadas e, entusiasmada, assistia ao cortejo se dispersava. Nesse momento, já estavam preparados três pontos de distribuição do "afogadão" para alimentar as pessoas que participaram do desfile.

Antes disso, na praça da catedral, a folia do divino da casa dos Açores cantava em frente ao império para o Divino Espírito Santo. Traziam uma coroa, uma rainha e uma bandeira. A folia tocava com quatro instrumentos de corda (violão, viola, bandolim e cavaquinho), um chocalho e um prato. Nas mãos de alguns componentes, três bandejas: uma trazia um pedaço de carne crua, e as outras duas um pão, conhecido como "massa do divino", que foram entregues aos festeiros e ao prefeito como forma de esmola.

Mário de Andrade traz uma descrição sucinta do cortejo no seu texto: "Logo depois da alvorada com foguete e bombas, um cortejo (uma 'procissão' como religiosamente os meus informantes qualificaram o cortejo), tendo á frente o festeiro, isto é, o Imperador do Divino eleito no ano anterior e cujo mandato está no penultimo dia, dirige-se a um determinado campo nos arredores, em busca dos palmitos. Os palmitos, essas palmeirinhas comuns em nossas regiões de campos, cortados junto á raís, já se acham empilhados sobre varios carros-de-bois. Chegada a procissão a esse lugar, que fica sempre a um quilometro mais ou menos da cidade, os carros-de-bois se movem com seus puxadores na frente. Forma-se então a procissão de volta á cidade, os carros abrindo o cortejo e atrás o festeiro e o povo, com a filarmonica fechando a romaria" (1937, p.52).

Em resumo, ainda assistimos nos dias de hoje à descrição que Mário de Andrade nos apresenta com uma pequena e sutil alteração. Antigamente, era costume os carros de boi saírem à frente do cortejo; hoje, porém, após reclamarem da sujeira (excrementos) deixada para trás pelos animais, as pessoas, sobretudo os festeiros e os políticos da cidade, passam antes dos bois e dos cavalos. Outro detalhe diz respeito à participação dos grupos folclóricos que, no passado, participavam na condição de "povo", conforme diz Mário de Andrade. Hoje, conforme relatamos 
acima, os grupos de congada e de moçambique são responsáveis pela abertura do cortejo, são eles que anunciam a entrada dos palmitos.

A entrada dos palmitos traz uma idéia de abundância, de riqueza, de consumo, de agradecimento a graças alcançadas e de retribuição. É uma festa dos pobres; de conversão da pobreza em abundância, exuberância e transbordamento de alegria.

Mário de Andrade disse, já quase no final do texto, que o imperador do divino (hoje representado na figura do festeiro) recebe mais ônus do que homenagens, pois cabe a essa pessoa propiciar essa abundância de comida, sobretudo de carne, que aparece no artigo com o nome de "refogado" e não "afogado", como é conhecido. Segundo Mário de Andrade, “o Imperador não é apenas o homem que organiza e paga os festejos semi-religiosos do seu culto do Divino: é principalmente, pro povo, o homem do qual todos comem e bebem, ás vezes por vários dias" (1937, p.63).

Inegavelmente uma aura mágica recobre a entrada dos palmitos por conta dos agradecimentos e dos suplícios ligados aos ritos protetivos e produtivos do ciclo agrícola rural e das técnicas de subsistência, colocando o homem em ligação com a natureza. Mais do que isso, os palmitos representam o modo como o divino chega ao mundo. A entrada dos palmitos significa a chegada do Divino Espírito Santo, o início de um novo tempo na terra.

NA FILA DO "AFOGADÃO" A entrada dos palmitos é coroada com a distribuição gratuita do "afogadão", como é chamado. Segundo o organizador do "afogadão", são preparados mais de cinco mil pratos. A produção do "afogadão" envolve a participação de mais de 30 voluntários e a doação de grandes quantidades dos ingredientes que constituem o prato (cerca de oitocentos quilos de carne). Além disso, exige-se das pessoas muita paciência, pois para conseguir obter um prato espera-se na fila mais de uma hora e meia, dado que não se trata apenas de comer o 
"afogado", mas como comer, ou seja, de forma cerimoniosa e longa. Os cinco mil pratos são consumidos em quatro horas de distribuição ininterruptas.

No mesmo espaço onde é realizada a quermesse, foram formadas duas filas: a primeira, à esquerda, era para o pessoal dos grupos que se apresentaram na entrada dos palmitos; a segunda fila era para todas as outras pessoas, os devotos em geral. O "afogado" foi servido num prato descartável de alumínio apoiado por uma base de isopor para as pessoas não queimarem as mãos. Uma porção de "afogado" tinha cerca de meio quilo de carne. Na base desse prato era colocada uma pequena porção de farinha de mandioca torrada e, em seguida, despejava-se o caldo quente com a carne cozida. Os pedaços de carne e de batatas eram grandes. A comida estava bem quente e extremamente saborosa. Até às $14 \mathrm{~h}$ ainda tinha gente sendo servida e todos puderam comer. A distribuição é uma forma de dádiva, uma indenização ao Espírito Santo pelos favores prestados ao longo do ano.

A comida servida ao final da entrada dos palmitos não deve ser pensada apenas como alimento, é preciso ter em mente as idéias de comensalidade e produção de corpos. Para Carlos Fausto, há dois modos de produzir identidade e diferença por meio do comer: de um lado, come-se com e como alguém para identificar-se e produzir-se mutuamente uma "comunidade de sentidos", ou seja, uma vida em comunidade é adquirida e produzida nas relações de troca da vida diária. Nesse sentido, a alimentação é vista menos como uma atividade que visa à produção de um corpo físico indeterminado, e mais como um dispositivo de produção de corpos. A comensalidade aparece como dispositivo identificatório. No contexto amazônico, segundo Fausto, a fabricação do parentesco converge, "para o universo da cozinha e da partilha alimentar" (2002, p.08).

Os alimentos postos à mesa traduzem a visão de ordem do mundo e evidenciam o caráter totalizante do social. Em nosso universo de pesquisa, a comensalidade do "afogado" é significativa porque o partilhar desse prato convertese em uma relação social entre sujeitos, pois o código culinário fabrica pessoas da mesma espécie. Segundo Fausto, “a comensalidade é um vetor de identificação que não se aplica apenas às relações sociologicamente visíveis entre parentes humanos" 
(2002, p.15). Trata-se de um dispositivo que ajuda a pensar a passagem de uma condição de parentesco para uma condição de familiarização.

O LUGAR DA COMIDA Observar a questão da alimentação é compreender as lógicas sociais de uma sociedade como um fato social total, que opera em distintas instâncias analíticas. A "conquista do paladar", sobretudo para as populações de origem rural, está associada ao preparo da comida e à idéia de abundância, razão pela qual as festas são importantes momentos de distribuição de grandes quantidades de comida. O sonho de uma boa comida é o antídoto mais eficaz contra a fome e o medo; o sonho de um bem-estar alimentar e de fartura abundante e inesgotável. Comida boa é comida farta com arroz, feijão, carne de boi, batata, legume, verdura, farinha, leite, pão, doce, café e cachaça tudo em grande quantidade e, de preferência, consumida de modo coletivo, mesmo que em momentos específicos.

As festas do catolicismo popular são momentos de distribuição e equilíbrio de alimentos, se constituem em cerimônias dramáticas de troca e retribuição, sobretudo de carne. Além disso, muitas pessoas doentes comem o alimento oferecido, pois acreditam em seus poderes terapêuticos na cura de enfermidades. $\mathrm{O}$ caipira, conforme Antonio Candido (1982), em capítulo que trata da dieta, é carente de proteínas. Portanto, a distribuição de alimento, não por acaso, é um ritual encontrado na maioria, senão em todas, das festas religiosas.

Em Mogi das Cruzes não é diferente, distribui-se, gratuitamente, ao final da entrada dos palmitos, o "afogado". O prato consiste basicamente em um cozido de carne bovina cortada em pedaços retangulares de mais ou menos cinco centímetros. Tudo é cozido em grande quantidade. Numa panela grande colocam-se carne fresca e água, tempera-se tudo com alho, cebola, sal, pimenta do reino, salsa, cebolinha verde e algum legume (geralmente batata e jiló). O cozido é servido num prato fundo com um pouco de farinha de mandioca. 
Cada pessoa conta uma história diferente sobre a origem do "afogado", todas elas girando em torno do mesmo tema, ou seja, um prato típico de Mogi das Cruzes à base de carne que uns atribuem aos tropeiros, outros aos primeiros sitiantes da região cujo nome está relacionado ao fato de ser pedaços de carne imersos na água para o cozimento. No entanto, a história contada por um casal de devotos é muito interessante. A mulher disse que não se trata da carne afogada no caldo, mas trata-se daquilo que está no fogo, ou seja, "fogado", a caminho de ficar pronto e cozido. $\mathrm{O}$ "fogado" seria o estágio intermediário entre o cru e o cozido. $\mathrm{O}$ longo tempo em que a carne fica cozinhando num fogo de lenha, cerca de seis horas, evoca a imagem de algo no fogo, da comida que está "fogada" num caldeirão abrasado. Essa história é acrescida de mais um detalhe: antigamente o "afogado" era feito somente à base de carne bem cozida com cheiro-verde, cebola e alho como tempero, consumido num prato com farinha de mandioca no fundo. Nos dias de hoje, houve o acréscimo de legumes: batata, tomate, salsão e jiló.

A técnica empregada não é, portanto, diferente daquela apontada por Claude Lévi-Strauss em O cru e o cozido (1991), dado que o cozido oferece menos riscos que outros tipos de técnicas. A oposição entre cru e cozido é fundamental, pois marca duas formas muito diversas de consumo, conforme aponta Carlos Fausto (2002), pois “devorar cru define, de saída, tanto a intenção quanto o resultado do ato de consumo, enquanto comer (bem) cozido define a intenção, mas guarda sempre uma ambigüidade, pois não se sabe jamais se o alimento foi completamente objetificado" (2002, p.18).

Em outro artigo, Lévi-Strauss (1967) trata da possibilidade de estudar uma sociedade a partir de sua cozinha. Para ele, a cozinha forma um "gustema" ao qual se organizam certas estruturas de oposições e correlações que se baseiam em três oposições: endógena/exógena (matérias-primas nacionais ou exóticas); central/periférica (base da refeição e complemento); marcada/não-marcada (saborosa ou insípida). Para Lévi-Strauss, no caso da cozinha camponesa no interior da Brasil, outras oposições se aplicam. A principal delas é entre assado e cozido (o assado é sensual, o cozido é nutritivo, sendo ambos mutuamente exclusivos). Além disso, há outras oposições incompatíveis, mas que possuem um valor normativo 
consciente para o grupo social, são elas: alimento calorífico/alimento refrescante; bebida leitosa/bebida alcoólica; fruta fresca/fruta fermentada etc. Esses exemplos foram usados para dizer que é possível atingir o significado das atitudes inconscientes da sociedade através da análise de uma gramática que a cozinha pode oferecer.

Antônio Cândido, em Os parceiros do Rio Bonito (1982), fala da importância do equilíbrio entre os mínimos vitais e sociais como fator de coesão do grupo. Para o autor, essa equação é simples: um grupo social e suas "necessidades básicas" não podem ser compreendidos separadamente do conjunto das "reações culturais". A alimentação, como recurso vital por excelência, corresponde a uma ligação ininterrupta do grupo com o meio. Antônio Cândido destaca a importância da alimentação como fator de vínculo social, representações e sistema simbólico. O autor explica: "sabemos no entanto que a obtenção, definição e elaboração de uma dieta dependem estreitamente de organização correspondente, e que os ritos agrários se encontram na base dos desenvolvimentos culturais mais surpreendentes. Vida, meio e grupo se integram e unificam muitas vezes em função dela" (1982, p.29).

Basicamente, a dieta do homem do campo, do ponto de vista histórico, consiste em feijão, milho, mandioca, e também arroz, alguns legumes, como a couve e a chicória, os condimentos e temperos como o sal, a gordura e o toicinho ligado à criação doméstica de porco, e o açúcar em forma de rapadura e garapa, mas também a cachaça (nunca dispensada). Por outro lado, como alimentos excepcionais, estão: o leite, o trigo (pão) e a carne de boi. Juntam-se a esses produtos, o café e outros alimentos obtidos na coleta, na caça e na pesca, acrescentando, assim, ao cardápio, algumas frutas, verduras e proteínas. Essa dieta pode ser observada nas mesas de muitos brasileiros não apenas de origem rural. Em Mogi, conforme observamos, opera uma lógica de classificação bem próxima à descrita por Antônio Cândido tanto no cotidiano, como em momentos extracotidianos.

As refeições diárias, que se dividem e se ordenam, mais ou menos, da seguinte maneira: refeições de sal, o almoço e o jantar. Basicamente, a categoria comida é arroz e feijão, geralmente acompanhados por farinha; o restante entra na 
categoria mistura, que pode ser uma carne, um ovo, uma verdura, um legume etc. A mistura predileta, evidentemente, é a carne, sobretudo a carne de boi fresca, que é mais rara. Para Antônio Cândido, as misturas ocupam sem cessar o desejo insatisfeito: "Elas constituem elemento importante nas representações mentais do caipira, sendo sem dúvida um dos fermentos que, nas condições atuais, o seu número aumenta teoricamente, diminuindo cada vez mais a possibilidade de adquiri-las" (1982, p.135).

A principal constatação de Antônio Cândido está no fato de que as populações rurais sofrem sucessivamente, em sua vida, uma perda na alimentação, tanto do ponto de vista do valor nutritivo, como dos hábitos alimentares. A obtenção dos alimentos se torna cada vez mais insuficiente na medida que o regime de auto-suficiência entra em declínio e o caipira é obrigado a adquiri-los através da compra. Um ponto de equilíbrio, nesse sentido, é a ajuda mútua (mutirão) entre vizinhos, constituindo um sistema de ampla troca, sob forma de presentes, prestações de serviço e das festas. Ou seja, esse hábito - como uma prática regulada pela tradição e pela etiqueta - de distribuir alimentos, sobretudo carne, é um espaço privilegiado de abundância e de solidariedade, mas não apenas, é o momento de coroamento do trabalho com a terra. Comer juntos os frutos do trabalho é devorar o próprio mundo, assim o trabalho se transforma em festa.

A festa é uma grande oportunidade de se consumir carne, principalmente as festas que ocorrem entre os meses de maio e agosto, que são as de maior importância no calendário agrícola. Pois, esse período de maior incerteza conhecido como a época de seca - é o momento em que se celebra as promessas feitas em prol de uma boa colheita. Além disso, nos momentos de festa e de consumo coletivos, muitas coisas se definem: relações de amizade, vizinhança, parentesco e reciprocidade.

Para Carlos Rodrigues Brandão, é importante notar o que se come e o que se conta enquanto se come, pois a cultura caipira vai da mesa ao mito. O trabalhador camponês quando fala da sua vida, fala sobre o trabalho, fala sobre o que produz, adquire e consome de alimentos. Segundo o autor, "entre as muitas e complexas atividades e relações da produção direta de alimentos de origem vegetal e animal; 
entre esforços por fazer circularem tipos de 'mantimento' e os momentos de consumo da comida, o lavrador emprega a maior parte do seu tempo de cotidiano e organiza o núcleo mais motivado de representações sobre o seu mundo" (1981b, p.08).

A classificação e a ordem dos alimentos discutido por Carlos Rodrigues Brandão assemelham-se às apontadas por Cândido: de um lado, os alimentos obtidos na natureza através da coleta (peixe, frutas, mel etc.); um grupo intermediário de produtos ingeríveis pela boca, mas não considerado comida (água, remédios caseiros, gordura (banha), condimentos, calda de doce e molho); e de outro lado, um terceiro conjunto obtido pelo trabalho na roça ou pela compra (arroz, milho, feijão, mandioca, carne etc). A divisão mais simples da comida é entre “animal" e "planta" (vegetal). Assim, como em Cândido, o que acompanha a comida é a mistura - sempre rara - e um conjunto de ingredientes que prepara e tempera a comida.

Para Brandão, os valores e as qualidades dos alimentos como comida estão estabelecidos através de pares de oposição: forte/fraca, quente/fria, reimosa/nãoreima, gostosa/sem-gosto. Segundo Brandão, "ao fornecer uma série de comidas opostas segundo cada um dos valores reconhecidos, os lavradores dão sinais de estarem conscientes de que classificam os seus alimentos em categorias, reunindo conjuntos de séries opostas uma à outra segundo a presença ou ausência de um atributo específico da comida" (1981b, p.108). Porém, o autor ressalta que não há uma classificação uniformemente modelada. É sempre importante ter em conta que as possibilidades de seleção e organização da dieta depende muito do lugar, da situação, do contexto, do momento e das influências do lugar. Apenas para exemplificar essas classificações com seus respectivos alimentos temos: feijão $=$ forte, arroz $=$ fraco. A comida forte é a que "tem sustança" com efeitos reconhecidos ao longo do tempo, especialmente em relação à energia assentada sobre o corpo para trabalhos mais pesados.

Elementos animais e vegetais ressoam em nosso universo de pesquisa. Mário de Andrade em seu artigo compara a entrada dos palmitos às cerimônias pagãs européias, especialmente em relação ao rito da "árvore de maio" e do Jorge Verde. 
Na Europa, segundo Mário de Andrade, os vegetais são usados como objetos de culto. A finalidade era trazer para as vilas ou próximo das casas os benefícios do espírito da árvore. O culto vegetal da primavera européia está ligado à idéia de fertilidade e a fecundação. Trata-se de unidades dotadas de força benéfica que trazem a chuva, os frutos da terra, o trabalho, a abundância, isto é, a alimentação e os meios de subsistência.

Para Mário de Andrade, o papel do cerimonial com vegetais em Mogi das Cruzes não é apenas decorativo, existe uma tradição profunda arraigada na cidade que ainda não foi discutida. Diz o autor: "não me parece possível que a Entrada dos Palmitos possa ser interpretada como espécie de mutirão apenas a ornamentar a cidade" (1937, p.53). O adorno é conseqüência de algo mais profundo. A própria palavra "entrada", para Mário de Andrade, "determina bem o propósito nuclear de fazer o vegetal entrar na cidade, carregando-o em forma processional, prova tratar-se exatamente dum culto" (p.53, grifo do autor).

Os carros de boi que acompanham o cortejo também têm sua importância. A passagem dos palmitos pela cidade é um espetáculo dramático que se desenvolve através desses carros cujo gemer dos eixos de madeira invadem a cidade ao som de música, de cantos e estrondos de fogos de artifícios no ar.

Segundo Mário de Andrade, o emprego de carros de boi e de palmitos não é simplesmente uma acomodação dos recursos regionais à festa do Divino, está ligado - para usar as palavras do autor - a essa "tradição importada". Certamente, são produtos derivados da região, mas profundamente ligados a tempos longínquos, ou seja, há um jogo equilibrado entre os recursos regionais e a tradição.

Mário de Andrade traça um interessante paralelo entre Mogi das Cruzes e a Europa: tanto de um lado como de outro, as cerimônias são associadas à fecundação; a festa do Divino aqui, e a festa de Maio lá; palmito aqui, pinheiro, bétula e louro lá. Em ambos lugares há o uso de mastros, a prática do cortejo em forma de procissão, a utilização de boi como transporte e a distribuição de alimentos vegetal e animal em abundância, além de doces para as crianças. Em suma, a entrada dos palmitos que culmina com a distribuição do "afogado", tanto no conceito como nos pormenores do rito, corresponde às práticas de culto vegetal que 
Mário de Andrade encontrou em Mogi das Cruzes e na Europa, principalmente a partir do trabalho de James Frazer exposto no Ramo de Ouro.

Mas a questão é saber porque elementos como palmitos e bois são evocados. Esses elementos tão significativos estão relacionados à lógica do sensível e as metáforas, a transformação da humanidade, da natureza para a cultura cuja aplicabilidade se dá principalmente em sociedades rurais onde o trabalho e a vida tendem a ser governados pelo ritmo sazonal e ecológico. Tudo isso nos remete, para usar as palavras de Geertz, para um mesmo significado: "a serenidade do divino transcendendo a fúria do animal" (Geertz, 1980, p.151).

Para Frazer, a escolha de adorar um vegetal (como o palmito, por exemplo) reforça o "caráter sagrado e o mistério da árvore, pois são o estranho, o maravilhoso, o raro, e não o familiar e o conhecido, que despertam as emoções religiosas da humanidade" (1982, p.74).

Um dos pioneiros a focalizar a relação entre humanos e não-humanos foi Philippe Descola (1986). Para ele, animais, vegetais, deuses e monstros podem também ser "pessoas" e ocupar a posição de sujeito na relação com os seres humanos. Humanos e animais estão imersos em um sistema sociocósmico no qual vários objetos estão em disputa, sobretudo potencialidades de existência e capacidades reprodutivas. Além disso, Descola não encontrou entre os Achuar povo que habita as terras altas do Equador - uma separação entre o mundo cultural da sociedade humana e o mundo natural da sociedade animal.

Mário de Andrade também cita alguns exemplos em que o homem atribui poderes espirituais em árvores e nos animais como forma de garantir a fecundidade através da chuva e da abundância da colheita e do gado. Além disso, os palmitos como adoração vegetal e os bois como adoração animal estão ligados à questão da vitalidade e da fertilidade, pois ambos são mediadores entre os mundos. O que está em jogo é o modo como a sociedade ganha vida. 


\section{ENTRE O SONO E A VIGÍLIA}

Como um elo de ligação entre o dia que marca a entrada dos palmitos e o dia da procissão de Pentecostes, ocorre na igreja do Carmo uma vigília que se inicia por volta das $23 \mathrm{~h}$ da noite, atravessa toda a madrugada e é finalizada pelo "ritual da fogueira". Como já foi dito, a igreja do Carmo é um complexo de duas igrejas barrocas da Ordem Primeira e Terceira, construídas respectivamente em 1633 e 1762. Porém, ao lado das capelas antigas, há uma capela nova extremamente confortável, com sistema de som, ventilação, telão e toda infra-estrutura para receber as pessoas. Nesse espaço é realizada a vigília de Pentecostes em que os devotos passam a noite rezando. Mas não apenas, pois durante a vigília são realizadas muitas atividades como encenação teatral para a Virgem Maria, discussões em grupo sobre temas bíblicos, músicas e o consumo de muita comida. Segundo Ginzburg (1991), aos bandos noturnos, geralmente guiados por mulheres, que vagueiam à noite são oferecidos bebida e alimento como garantia de prosperidade para a casa e a família. As reuniões noturnas são histórias variadas de caças noturnas, de perigos noturnos, momento em que os mortos vagueiam pela noite.

Ao final da vigília ocorre um encontro em frente à igreja barroca com os devotos vindos da última alvorada que juntos realizam o ritual da "fogueira de Pentecostes". Esse procedimento é uma espécie de rito purificador que finaliza um período e inaugura um novo tempo. Segundo o frei que conduziu o rito, a imagem da natureza que melhor expressa a presença de Deus é o fogo, que aquece a fé dos devotos, queima todo o mal e confirma o triunfo do Reino de Deus. Para ele, o Espírito Santo, que se realiza em forma de fogo, é capaz de afastar os malefícios e eliminar os demônios. Na oração final, as pessoas colocaram as mãos nas cabeças das outras, rezaram em silêncio e fizeram pedidos que seriam queimados naquele momento. Com esse ritual da fogueira, encerra-se um período suspenso no sábado pela manhã e inicia-se, como uma fênix renascida das cinzas, um novo tempo na terra. 
Para Ginzburg (1991), a vida está no registro do diurno, ao passo que a morte está no registro do noturno. Entre um ponto e outro, o tempo pára. No período de duração da vigília, vela-se a noite toda. No drama barroco, o tempo é noturno: nele há ruínas, esqueletos, crânios e fantasmas. Durante o ritual da fogueira (que durou cerca de quinze minutos), o dia foi amanhecendo lentamente. Os primeiros raios de luz apareciam por detrás da igreja barroca enquanto a procissão partia para o salão da catedral onde o café seria servido. Às $6 \mathrm{~h}$ em ponto o cortejo chegou no império ao som dos sinos da catedral e sob a luz do novo dia, o dia de Pentecostes, encerrava-se as alvoradas. No encerramento, muitas pessoas se emocionavam e choravam. O pároco da catedral veio até o império e fez uma oração à Virgem rezando uma Ave Maria.

\section{A PROCISSÃO DE PENTECOSTES}

A procissão do domingo de Pentecostes encerra as celebrações da festa do Divino. O dia de Pentecostes é a ocasião em que se celebra a descida do Espírito Santo em forma de línguas de fogos sobre os apóstolos e Maria, que estavam reunidos no cenáculo.

Os cortejos expressam dramaticamente histórias de dominação, a história dos vencedores. Walter Benjamin disse que "todos os que até hoje venceram participam do cortejo triunfal, em que os dominadores de hoje espezinham os corpos dos que estão prostrados no chão" (1985, p.225). Na bíblia, há referências desse mesmo tipo. No Salmo 68, é descrita a história da luta do povo de Deus. Após encerrar a batalha em que Deus venceu seus inimigos, os vencedores desfilam em cortejo:

"O teu cortejo apareceu, ó Deus, o cortejo do meu Deus, do meu rei, a caminho do santuário.

$\mathrm{Na}$ frente marcham os cantadores, 
Atrás os tocadores de harpa,

No meio os jovens, tocando pandeiro" (Salmo 68).

O CORTEJO A sóbria procissão em louvor ao Divino Espírito Santo é o momento de maior demonstração de religiosidade para os devotos da cidade, da qual participam em grande número. No ano de 2004, o clima frio e chuvoso do domingo de Pentecostes contrastava com o clima quente e ensolarado da entrada dos palmitos no dia anterior.

A procissão foi composta da seguinte maneira: à frente, abrindo o cortejo, um grupo de lanterneiros (15 lanternas brancas e uma vermelha). Logo atrás, em fila dupla, as irmandades, que não desfilaram na entrada dos palmitos. São elas: São Benedito, Sagrado Coração de Jesus, Ordem Terceira de Nossa Senhora do Carmo, Santana, Santíssimo Sacramento. Esses foram seguidos por crianças vestidas de anjinhos, pelos ex-festeiros e ex-capitães do mastro (são treze casais no total, ou seja, todos os casais desde 1993) e jovens que carregavam três símbolos: uma âncora, um coração e uma cruz, que significa fé, esperança e caridade, respectivamente. Havia, ainda, jovens com estandartes com os sete dons do Divino Espírito Santo e suas cores correspondentes (sabedoria, azul; entendimento, prata; conselho, verde; fortaleza, vermelho; ciência, amarelo; piedade, azul-marinho; e temor a Deus, roxo). Antes do bispo diocesano, ainda iam os devotos com bandeiras e o carro de som. Os sete dons foram colocados, em forma de totens nas casas das pessoas e, ao longo do trajeto da procissão, em cada um fazia-se uma parada e o bispo explicava o significado daquele dom e soltava uma pombinha branca, simbolizando os espíritos em libertação. Nesse momento, fogos de artifícios eram estourados e a procissão seguia rezando o terço muitas e muitas vezes. Logo atrás do bispo, o imperador (um casal de crianças), o casal de festeiros e de capitães do mastro que traziam a coroa e o cetro. Na seqüência, outros grupos de jovens. O primeiro deles trazia as bandeias do divino, do Brasil, da cidade de Mogi das Cruzes, do estado de São Paulo, do estado do Vaticano, além de uma bandeira branca. Outro grupo de jovens ostentava 
estandartes e tochas. Atrás desses jovens vinham as rezadeiras com suas caixinhas de pedido, que seriam incinerados ao final da missa. Essas eram seguidas por jovens vestidos de anjos, cerca de vinte. O ponto alto da procissão é o andor. Todo enfeitado e iluminado, ele traz no alto a imagem da pomba. Esse momento é deveras emocionante, muitas pessoas choravam, aplaudiam e diziam: "Que lindo!", “Viva o Divino Espírito Santo!”. O andor é feito de madeira e ferro e fica num lugar reservado durante o ano todo, sendo apenas visto na ocasião da procissão. Fechando o cortejo, soldados do Tiro de Guerra, que protegiam o andor, a banda Santa Cecília, devotos carregando as bandeiras do divino (centenas) e, no final, a congada Nossa Senhora do Rosário, a congada Santa Ifigênia, congada Batalhão Nossa Senhora Aparecida, o moçambique São Benedito e Nossa Senhora do Rosário, o moçambique São Benedito, Bom Jesus e Nossa Senhora do Rosário e a congada de São Benedito - Império de César.

A procissão, que tinha saído atrasada devido à chuva, foi surpreendida por alguns momentos de maior intensidade, lavando, literalmente, a alma dos devotos. Parte do tapete ornamental foi danificada pela chuva. Interessante que o tapete, na verdade, tomou formas diferentes daquelas que tinham sido feitas originalmente, meio estranhas e retorcidas. As pessoas ficaram preocupadas com a chuva, algumas mais indignadas diziam: “Tanto dia pra chover, justo hoje?!", “O Espírito Santo é forte", "Deus sabe o que faz".

O tapete ornamental é confeccionado na manhã do domingo, último dia da festa. A organização e produção são de responsabilidade da Diretoria de Ensino do Estado da Educação - Região Mogi das Cruzes, pela Dirigente Regional de Ensino, pela Secretaria Municipal de Educação e pela Associação Pró-Festa do Divino Espírito Santo. O tapete é formado por quadros temáticos e uma passadeira que liga um quadro ao outro.

Num determinado ano, o tapete ornamental foi montado da seguinte maneira: abrindo o conjunto de quadros e passadeiras, a contribuição do Liceu Braz Cubas com o seguinte lema: “Ó Senhor Deus da vida que cuida de toda a criação dános a paz". Em seguida, o Colégio Policursos com o lema: "Que nossa segurança não venha das armas, mas sim do respeito". A Escola Estadual Prof. Maria Isabel 
dos Santo Mello produziu uma passadeira. A Escola Estadual Prof. Laurindo Cardoso Mello Freire um tapete com o lema: “Que nossa força não seja a violência, mas o amor". O Colégio Estrutural trouxe o lema: "Que nosso caminho não seja a ambição e o dinheiro, mas a justiça e a partilha". O Grupo de Jovens da igreja Cristo-Rei fez uma passadeira. O grupo de violões Ivo Fernandes produziu uma passadeira e um tapete com o lema: "Que nossa vitória não seja a vingança, mas o perdão". A UNAI/UBC fez uma passadeira e um tapete com o lema: "Ó Senhor Deus, hoje e sempre, dá-nos o pão da solidariedade e do amor". O Grupo de Escoteiros Ubirajara fez uma passadeira. A Vila Santista Esporte e Recreação, uma passadeira e um tapete sobre a quermesse. A Escola Estadual Helena Urbano Nagib, a Escola Estadual Reverendo Prof. Osmar Teixeira Serra e a Escola Estadual Aristóteles Andrade produziram um tapete sobre a entrada dos palmitos. O grupo de Jovens da igreja Nossa Senhora do Socorro, uma passadeira. A Escola Estadual Conjunto Toyana fez uma passadeira e um tapete sobre as "danças folclóricas", juntamente com a Escola Estadual Antonio Olegário dos Santos Cardoso que também fez um tapete sobre as "danças folclóricas". O SESI (Serviço Social da Indústria) fez um tapete sobre os subimpérios. A APAE (Associação de Pais e Amigos dos Excepcionais de Mogi das Cruzes), sobre o lema da festa daquele ano: “fé, esperança e caridade". A Escola Estadual Prof. Camilo Faustino de Mello, o dom da sabedoria. A Escola Estadual Prof. Cláudio Abrahão, o dom do entendimento. A Escola Estadual Dr. Deodato Wertheimer, o dom do conselho. A AMOA (Associação Mogiana - Oficina dos Aprendizes), o dom da fortaleza. A Escola Estadual Vereador Narciso Yague Guimarães, o dom da ciência. A Escola Estadual Prof. Jonita Franco Arouche, o dom da piedade. O Colégio Integrado de Mogi das Cruzes - Objetivo, o dom do temor a Deus. A Escola Estadual Prof. Paulo Ferrari Massano fez uma passadeira. O Grupo Fé no Divino fez um tapete sem tema. A Escola Estadual Francisco Ferreira Lopes fez um tapete sobre o Ano Eucarístico. A Escola Estadual Narciso das Dores Pinto fez uma passadeira e a catedral ficou responsável por um grande tapete em frente à igreja sobre o Pentecostes. Os principais materiais usados foram: serragem, quartzo, areia colorida, tampinha de garrafa, papel e papelão. 
A presença do tapete ornamental, uma tradição trazida de outras festas, revela o caráter barroco da festa do Divino cuja permanência de alguns elementos se juntam a fragmentos de outras celebrações revelando, ao modo do bricoler, um “arranjo totalmente insólito de um todo desconhecido” (Montes, 1998a, p.152).

Em 2005, a procissão foi diferente do ano anterior. O clima estava agradável, fazia calor, as pessoas estavam nas calçadas, com cadeiras nas ruas assistindo à procissão; outras pessoas inclusive faziam o percurso descalças. Nesse ano, a procissão de Pentecostes foi montada da seguinte maneira: 


\section{PROCISSÃO dE PENTECOSTES}

\begin{tabular}{|c|c|}
\hline CARROS DA POLÍCIA MILITAR & 1 \\
\hline LANTERNAS E ESCOTEIROS & 2 \\
\hline $\begin{array}{l}\text { IRMANDADES: SÃO BENEDITO, SAGRADO CORAÇ̃̃O DE JESUS, } \\
\text { ORDEM TERCEIRA DE NOSSA SENHORA DO CARMO, SANTANA, SANTISSIMO SACRAMENTO }\end{array}$ & 3 \\
\hline ANJINHOS (CRIANÇAS) & 4 \\
\hline DEVOTOS & 5 \\
\hline $\begin{array}{l}\text { BANDEIRAS: BRASIL, BANDEIRA BRANCA E DO DIVINO, } \\
\text { ESTADO DE SÄO PAULO, VATICANO E MOGI DAS CRUZES }\end{array}$ & 6 \\
\hline CASAIS DE EX-FESTEIROS E EX-CAPITÃES DO MASTRO & 7 \\
\hline REZADEIRAS & 8 \\
\hline CARRO DE SOM E CANTADOR & 9 \\
\hline MENINAS COM ÂNCORA, CORAÇÃO E CRUZ & 10 \\
\hline OS SETE DONS & 11 \\
\hline BISPO E AUXILIARES & 12 \\
\hline MENINAS DE DOURADO & 13 \\
\hline ANJINHOS DE DOURADO (MENINAS) & 14 \\
\hline ANJINHOS DE BRANCO (MENINOS) & 15 \\
\hline ANDOR & 16 \\
\hline TIRO DE GUERRA & 17 \\
\hline TOCHEIROS & 18 \\
\hline BANDA SANTA CECÍLIA & 19 \\
\hline DEVOTOS & 20 \\
\hline CONGADA NOSSA SENHORA DO ROSÁRIO & 21 \\
\hline CONGADA SANTA IFIGÊNIA & 22 \\
\hline CONGADA BATALHÃO NOSSA SENHORA APARECIDA & 23 \\
\hline CONGADA DE SÃO BENEDITO - IMPÉRIO DE CÉSAR & 24 \\
\hline MOÇAMBIQUE SÃO BENEDITO E NOSSA SENHORA DO ROSÁRIO & 25 \\
\hline BLOCO DE LIMPEZA & 26 \\
\hline
\end{tabular}


No final da procissão, o ápice da emoção e o clímax da dramaticidade: a imagem do divino é retirada do andor e introduzida na catedral de Santana. Completamente lotada e tomada pela emoção, as pessoas que se encontravam no interior da igreja aplaudiam e choravam. Lágrimas corriam dos olhos dos fiéis; um coral cantava a música de abertura da missa de Pentecostes, o som ecoava por todos os lados; gritos de “Viva o Divino Espírito Santo!” eram repetidos várias vezes. Enquanto isso, do lado de fora, os grupos de congada e de moçambique continuavam tocando sem parar no quadrilátero da praça central com uma energia incrível. Suores corriam dos rostos dos componentes dos grupos, numa mistura de dor e agradecimento que se misturava com a chuva fina que caía. No meio da praça, dividido em duas metades entre o império e a catedral, dança e música, muita música, permeada de orações. Assim como na igreja, muita gente acompanhava os grupos na praça. Um verdadeiro teatro popular de rua foi instaurado. O som da rua invadia o som da igreja, sobretudo para aqueles que estavam perto da porta. Havia um entrelaçamento de sons entre um lado e outro, que não era possível de definir o que era um e o que era outro. Espanto, barulho, fogo e línguas diferentes, ou seja, a mais pura expressão do Pentecostes. Chuva, suor e lágrimas se misturavam com as cores e sons da fé no Divino Espírito Santo.

A multidão que se aglomerou em frente à catedral acompanhou a missa por meio de um telão instalado do lado de fora para aqueles que não puderam entrar na igreja lotada. Ainda do lado de fora, uma equipe da limpeza rapidamente, como um passe de mágica, retirava todo o material usado no tapete que tinha ficado completamente desfigurado no final da procissão. Meia hora depois, após um rápido trabalho de uma equipe de limpeza pública da cidade, as ruas já estavam completamente limpas.

No caderno de campo registramos que os grupos folclóricos não têm o mesmo lugar de destaque na procissão de Pentecostes como ocorre na entrada dos palmitos; as coisas parecem não se encaixarem. Os coordenadores não os deixam fazer "barulho", dizem quando e qual é o melhor momento para eles se manifestarem. Inversamente ao que acontece na entrada dos palmitos, eles seguem 
no final do final. Aparecem quando permitem e são ocultados em outros momentos pela equipe de coordenação que caminha junto à procissão portando rádios e telefones celulares, vestindo terno escuro e gravata vermelha. Aliás, não é de hoje que isso acontece, a cultura negra vem passando por um processo de folclorização há muito tempo, conforme aponta João Baptista Borges Pereira (1983), sendo vista, de um lado, como algo "pitoresco", e de outro, sendo valorizada como elemento de mediação para ascensão social.

O que aparece no primeiro dia na entrada dos palmitos, não aparece no segundo. O que está luminoso no primeiro momento está opaco no segundo. Até as emoções são diferentes. Segundo os esquemas apresentados acima, o movimento da entrada dos palmitos é aparentemente caótico, pois desde o início do dia o trânsito da cidade é interrompido. O cortejo parte do alto em direção à catedral de Santana onde faz uma curva e retorna para o ponto inicial em forma de um nó entrecruzando espaços, pessoas e animais. A procissão de Pentecostes, por sua vez, tem um movimento rítmico marcado por uma marcha solene e ordenada que parte da catedral e retorna ao mesmo ponto em forma de círculo. Há uma ordem rigorosa que é rigorosamente diferenciada nos dois cortejos. Nesses dois momentos encontramos "idéias e imagens do cosmos e do caos, interdigitando palhaços e suas folias com deuses e suas solenidades, e fazendo uso de todos os códigos sensoriais para produzir sinfonias para além da música" (Turner, 2005, p.184).

A QUEIMA DOS PEDIDOS Se a entrada dos palmitos é encerrada pela distribuição do "afogado", a procissão de Pentecostes encerra-se com a queima dos pedidos recolhidos pelas rezadeiras desde o início do ano e ao longo dos onze dias de festa. Destaca-se, nos dois casos, a presença do fogo que simboliza a energia transformadora dos atos do Espírito Santo. Nesse último caso, são queimados todos os papéis e fitas das bandeiras que contêm os pedidos impressos na tentativa de transportar para o além os desejos e os sonhos dos devotos. 
Às 20h do domingo de Pentecostes, concentrado em frente ao império do divino, um grupo de congada tocava ao lado de um caldeirão, no qual seriam queimados os pedidos. $\mathrm{O}$ festeiro e o capitão do mastro se aproximavam trazendo junto deles as rezadeiras com as caixinhas de pedidos nas mãos. Logo atrás, o bispo e seus auxiliares. As rezadeiras, juntamente com as outras pessoas que estavam ali, fizeram um círculo em volta do fogo fatal que iria consumir os pedidos. O bispo se aproximou do caldeirão, solicitou o auxílio de um outro bispo, abençoou os pedidos com água benta e disse: "Se for da vontade de Deus que esses pedidos sejam realizados". As rezadeiras abriram as caixas, o bispo abençoou novamente e pediu para que elas jogassem, lentamente, os papéis com os pedidos no caldeirão. O bispo, pessoalmente, pegou alguns papéis, colocou no caldeirão e disse: “já vimos a fumacinha, agora podemos ir embora", se despediu e saiu sorridente enquanto as pessoas queimavam os pedidos. O fogo causava uma fumaça insuportável, mesmo assim as pessoas permaneciam próximas. Esta fumaça era o veículo que transportava para os céus os pedidos a serem atendidos e os agradecimentos de graças recebidas. Aos poucos alguns foram se retirando e só sobraram algumas rezadeiras que ainda tinham muitos pedidos para serem queimados. Na porta do império ainda havia uma fila e muitos pedidos estavam por vir. Primeiro foram queimados os pedidos de papel, por último os pedidos feitos nas fitas. Era incrível, milhares e milhares de pedidos eram retirados das caixinhas. Lentamente os ambulantes da praça começaram a desmontar as barracas e a se retirar. A praça, que estivera agitada durante dez dias, começava a ficar vazia. No final, depois de mais de duas horas de fogo queimando, havia três rezadeiras, dois soldados do Tiro de Guerra que ficariam por ali até o fechamento do império, alguns transeuntes, funcionários do serviço de limpeza urbana que varriam a praça, alguns devotos e um pesquisador.

No final da festa, todos estavam exaustos. Tentamos acompanhar a maioria dos eventos e observá-los de perto na maior parte do tempo. Incomodado com o próprio cansaço, indagamos algumas pessoas como elas conseguiam acompanhar tudo e ainda continuarem com expressão de felizes e despertas. Dois tipos de 
respostas foram dadas: a primeira era por causa da fé; a segunda era porque nem todos, de fato, acompanhavam tudo que se transcorria durante os mais de dez dias, as pessoas acompanhavam a festa parcialmente. Essa resposta faz compreender que a totalidade da festa está na cabeça do pesquisador que tem de constituir um todo abstrato para depois dissecá-lo em partes. O cientista social constrói abstrações de totalidades retiradas de observações da realidade concreta que ocorre nos fragmentos desse todo. Os eventos que compõem a festa são, muitas vezes, eventos isolados. A união desses eventos forma a totalidade da festa do Divino Espírito Santo.

\section{MONTAGENS CRIADORAS DE IMAGENS}

Há algo estranhamente familiar no cortejo da entrada dos palmitos. Usando as palavras de Dawsey, diríamos que "fragmentos de tradições aparentemente longínquas se articulam ao presente de forma eletrizante" (1998, p.81). Por outro lado, a procissão de Pentecostes traz uma pedagogia de valores cujas imagens são montadas didaticamente e estão a serviço da devoção ao Espírito Santo; não é por acaso que ocorre a participação de crianças e jovens no cortejo.

O conceito de montagem surge como categoria que possibilita não divorciar a teoria da manifestação do sensível e também expor as tensões de imagens sobrepostas. Numa seqüência de eventos, os elementos estão todos juntos e se comunicam através daquilo que Eisenstein introduziu no cinema e a antropologia tomou emprestado: o conceito de montagem. O papel da montagem, segundo Eisenstein (1990), é expor o tema de modo coerente e orgânico, bem como da história e da ação, ou seja, a simples forma de narrar uma história de forma coesa, com lógica, continuidade e emoção dentro do drama, no seu todo. Porém, não se trata apenas, tanto no cinema como em outras artes, de colocar lado a lado dois ou 
mais elementos para se obter uma seqüência coesa de imagens, mas de elaborar novos conceitos dos fenômenos e dos fatos através da justaposição de imagens. A tensão de elementos contrários justapostos nos cortejos evoca a idéia de montagem.

$\mathrm{Na}$ entrada dos palmitos, encontramos a criação de imagens reais e concretas de fontes de vida, ao passo que na procissão de Pentecostes imagens do passado articulam-se ao presente num momento de tensão. A procissão de Pentecostes é uma apoteose precedida pelos palmitos e carros de boi. A montagem articula imagens que nunca se distingue do sensível. A montagem cria imagens.

Um exemplo de Eisenstein nos ajuda a entender melhor o sentido da justaposição. "Tomemos um túmulo, justaposto a uma mulher de luto chorando ao lado, e dificilmente alguém deixará de concluir: uma viúva" (1990, p.14, grifo do autor). O efeito que se busca é construir, devido à convenção estabelecida, a idéia de que a mulher chora a morte do marido, quando na realidade se trata de seu amante. Fundamentalmente, “a justaposição de dois planos isolados através da união não parece a simples soma de um plano mais outro plano - mas o produto. Parece um produto - em vez de uma soma das partes - porque em toda justaposição deste tipo o resultado é qualitativamente diferente de cada elemento considerado isoladamente" (1990, p.16, grifos do autor). As partes são representações ao passo que a justaposição das representações forma uma nova idéia, um novo conceito, uma nova imagem.

A entrada dos palmitos e a procissão de Pentecostes podem ser lidas como textos dramáticos possíveis de serem interpretados em sua própria linguagem, ou seja, nas formas sensíveis de representação. O que chama a atenção nesses cortejos é o aspecto alegórico e sua montagem através de justaposição de imagens como se fossem imagens de espelho sobre imagens de espelho. A entrada dos palmitos apresenta-se como um desfile e desenvolve-se como um drama, pois o desdobramento desse desfile baseia-se numa montagem alegórica e ordenada. Nesse sentido, há aquilo que Eisenstein chama de "unidade orgânica" da montagem cujos elementos do todo participam de cada fragmento. Do ponto de vista da ação, os quadros que compõem o todo diferem uns dos outros, mas, organicamente, o 
Divino Espírito Santo perpassa todos eles. Ou seja, há uma aparente coesão e harmonia no cortejo. Porém, até que ponto esse desfile é orgânico e harmônico? Vêse claramente que os fragmentos pouco (ou nada) se comunicam. Em cada quadro da "composição orgânica", o conflito salta para fora de si, pois, como diz Eisenstein, “é no próprio movimento da obra que se descobre 'o segredo' de sua unidade orgânica" (1969, p.70). Observando os dois cortejos evidenciamos uma ordem moral e social a partir do lugar ocupado por cada um, na forma como são organizados e dispostos em procissão, dos elementos destacados, da hierarquia estabelecida, do prestígio e do poder.

Cada quadro que compõe a entrada dos palmitos (ou a procissão de Pentecostes, que também se desenvolve em quadros) representa uma unidade em si. De acordo com Eisenstein, "a montagem tem um significado realista quando os fragmentos isolados produzem, em justaposição, o quadro geral, a síntese do tema. Isto é, a imagem que incorpora o tema" (1990, p.26).

$\mathrm{Na}$ montagem, as imagens estão carregadas de tensões, pois a própria montagem evoca as rupturas, interrupções e travessias das histórias de vida dos devotos presentes nos cortejos. Para Victor Turner, essas imagens justapostas articulam as diferenças e constituem um "mecanismo" 20 de ajuste e restabelecimento de tensões da vida social da cidade.

Para Michael Taussig (1993), a montagem interrompe a ordem ilusória em relação àquilo que, inicialmente, parecia ser a ordem natural e, mais tarde, assume ser mais do que uma desculpa da ordem. O modo pelo qual ocorre a interrupção, a súbita alteração das coisas e das disposições da cena rompe com qualquer tentativa de ordenamento da narrativa convencional. Na montagem, conexões esquecidas ou ocultas do passado são reveladas pela justaposição de imagens.

Os fragmentos justapostos evocam imagens de conflitos e rupturas na vida das pessoas que participam dos desfiles, bem como da vida da cidade. Para Taussig, as percepções são sentidas através da montagem que é capaz de estabelecer "súbitas e infinitas conexões entre dessemelhantes, em um processo interminável, ou quase,

${ }^{20}$ Victor Turner se refere à terceira fase do modelo de drama social, a ação reparadora. 
de estabelecimentos e ruptura de conexões" (1993, p.411). Segundo Taussig, é nos momentos de interrupção que ocorrem as mudanças. As situações se alteram subitamente nas fendas e nas brechas da vida social ordinária. A entrada dos palmitos é o momento em que as margens estão no centro, momento de inversão simbólica.

Cada um dos elementos que compõem a procissão, o tapete ou a entrada dos palmitos forma uma unidade em si, uma unidade menor que integra uma unidade maior. Dessa maneira, tanto a entrada dos palmitos quanto a procissão de Pentecostes mostram a natureza da bricolage material e espiritual da festa na “tentativa de construção de uma ordem inteligível do mundo a partir de sua expressão sensível" (Montes, 1998a, p.151).

Associações surpreendentes e elementos arredios irrompem ao nível da superfície da cidade através dos cortejos apresentados. No próximo capítulo, seremos surpreendidos por duas figuras femininas cujas imagens refletem uma à outra e provocam uma reflexão sobre a festa do Divino e a cidade de Mogi das Cruzes. 


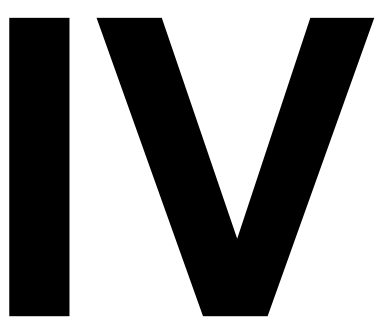

\section{NHÁ ZÉFA: ENTRE A VIRGEM E A ONÇA}

Este último capítulo aponta para o não-resolvido, para o suprimido, para as tensões, liminaridades e ambigüidades que aparecem na festa do Divino Espírito Santo de Mogi das Cruzes. O capítulo final conta a "história dos secundários e das margens" (Foucault, 1972, p.169). Por essa razão, temos justamente como fio condutor uma figura muito popular na festa conhecida como Nhá Zéfa Onça. Falecida em 1991, participou da festa pela última vez em 1990. Ela costumava desfilar na entrada dos 
palmitos montada em um cavalo todo enfeitado com as cores do divino, em especial o vermelho e o branco. A história dessa antiga personagem na festa é cercada de mistério e diz muito sobre as esperanças depositadas em Nossa Senhora.

Para Victor Turner (2005), “a liminaridade pode talvez ser escrita como um caos frutífero, um armazém de possibilidades, não uma montagem aleatória, mas uma busca por novas formas e estruturas, um processo de gestação, uma irrupção fetal de modos apropriados de existência pós-liminar" (pp.183-184). O que se procura discutir tem como ponto de partida as reflexões de Victor Turner sobre o domínio do ambíguo, do liminar, da passagem e das possibilidades de utilizar essas dimensões como um paradigma viável para o estudo da sociedade.

O lugar da ambigüidade é o espaço que o sistema de classificação não cobre. Para Edmund Leach (1983), a natureza da classificação não dá conta de todo o universo, sempre existirão espaços vagos a serem preenchidos. Para o autor, "é precisamente esse meio, essas zonas intersticiais que provocam a dinamização de todo o sistema, abrindo questões e provocando dificuldades na classificação" (p.47). Portanto, as margens tratam de elementos que ficam entre categorizações manifestas e nítidas da realidade humana. Nesses espaços surgem áreas híbridas e de ambigüidades com poderes de revitalizar o tecido social. Imagens do passado articulam-se ao presente num momento de interrupção do cotidiano.

Por outro lado, buscamos ler uma situação social através daquilo que o teatrólogo Bertold Brecht chamou de gestus social. Para Brecht, o gestus social é uma situação social carregada de conflitos, tensões e contradições em que as indeterminações do familiar são trazidas à tona. Para Benjamin, "o teatro épico é gestual [...] o gesto é seu material, e a aplicação adequada desse material é sua tarefa" (1985, p.80). Para ele, o teatro épico é um teatro da interrupção, quanto mais interrupções mais gestos se obtêm.

As afinidades entre as formulações de uma antropologia da performance de Turner e o teatro épico de Brecht voltam-se aos elementos estruturalmente arredios, 
aos ruídos e às interrupções. Diferentemente de Erving Goffman, que toma a vida cotidiana como um teatro, Turner interessa-se pelo meta-teatro e "procura focar os momentos de interrupção, os instantes extraordinários, ou seja, o teatro desse teatro" (Dawsey, 2005a, p.174). O teatro de Brecht busca alterar relações. O palco não é mais um espaço sagrado, mas uma tribuna, uma "sala de exposição" cujo ângulo de visão das pessoas interessadas é favorável.

O efeito de distanciamento produzido no teatro épico de Brecht busca tirar do incidente ou da personagem aquilo que é manifesto, conhecido ou óbvio, despertando em torno deles espanto ou curiosidade. Para Anatol Rosenfeld, ver "as coisas sempre tal como elas são, elas se tornam corriqueiras, habituais e, por isso, incompreensíveis. Estando identificados com elas pela rotina, não as vemos com o olhar épico da distância, vivemos mergulhados nesta situação petrificada e ficamos petrificados com ela" (1965, p.152).

Duas peças de Brecht apresentam personagens cujos papéis sociais servem de referência aos desempenhados por mulheres como Nhá Zéfa. Em "Santa Joana dos Matadouros", Joana Dark, a "tenente" dos "boinas pretas", despoja-se de toda vaidade e coloca-se ao lado dos trabalhadores nos matadouros. No início da peça há um embate entre Joana e o patrão. Este tenta mostrar a ela a maldade dos pobres. Joana diz que não se trata de ver a maldade, mas a "pobreza dos pobres". Imediatamente, os jornalistas passam a chamá-la de "Virgem dos matadouros" e, em seguida, de "Santa Joana", tornando-a numa vedete. Sua fama de santa cresce com o apoio da mídia e dos patrões. "Precisava ter mais mulheres assim" (1990, p.119), diziam os trabalhadores no dia de sua morte.

Para Dawsey, “a figura de Joana D'Arc apresenta as associações entre 'mulheres santa' e 'homens arregimentados' numa imagem única. Aqui, porém, esses homens, formando um exército, entram em guerra contra aqueles que os oprimem - com uma 'mulher santa e guerreira' a frente" (1998, p.318). 
Numa outra peça de Brecht, "Mãe coragem e seus filhos", uma vendedora ambulante chora a morte de seus filhos numa guerra em que ela ganha o seu sustento vendendo mercadorias para as tropas esfarrapadas. Mãe coragem, que teve vários homens de diferentes nacionalidades, "chora por aqueles cujo sacrifício é exigido por uma guerra à qual, por questões de sobrevivência, ela mesma contribui" (Dawsey, 1998, p.240).

As contradições emergem nos pensamentos de Mãe Coragem o tempo todo, conforme texto do Brecht:

- A guerra é uma bonita fonte de renda.

[na fala seguinte].

- Maldita seja a guerra!

Em "Mãe coragem e seus filhos", a figura principal é perpassada por ambigüidades e encarna contradições. Mesmo arrasada pelos 100 anos de guerra, após a morte dos seus filhos, mãe coragem ainda tem forças para subir na carroça e dizer: “Agora o jeito é começar tudo outra vez" (1991, p.265).

No palco brechtiano, distinções rígidas entre atores e público são transgredidas, há um estranhamento em relação ao familiar. Uma atriz brechtiana toma distância de seu personagem. Assim, mulheres viram bichos, como a mulher lobisomem do parque de diversões em Aparecida do Norte estudado por John Dawsey (2000). Para Bakhtin, a imagem da mulher na tradição cômica e popular da Idade Média e do Renascimento é ambivalente, liga-se ao baixo-corporal e ao grotesco com mutações que envolvem formas de seres humanos e animais. De acordo com Bakhtin, “a mulher rebaixa, reaproxima da terra, corporifica, dá a morte; mas ela é antes de tudo o princípio da vida, o ventre (2002, p.209, grifos do autor).

Este capítulo apresenta duas imagens femininas análogas que se complementam através do "espelho mágico" da performance (Turner, 1987). Espelho em que a sociedade vê a si própria a partir de diversos ângulos. Espelho 
que não apenas reflete o real, mas provoca a reflexão sobre esse real. Assim, tentaremos ver Nossa Senhora não em sua imagem tranqüila e serena, mas através de uma mulher que vira onça. A imagem aparentemente caótica de Nhá Zéfa serve para celebrar o cosmos encontrado em Nossa Senhora.

\section{NHÁ ZÉFA, UMA MULIER FORTIS}

Nhá Zéfa é Josefina Franco de Camargo. Nasceu em 21 de julho de 1902 e morreu em 11 de setembro de 1991: segundo a certidão de óbito ela teria 89 anos. A data de nascimento e a idade, porém, não são confirmadas pelos parentes. Dos pais não há qualquer informação de data de nascimento e origem. As netas dizem que ela nasceu antes da data confirmada no documento e faleceu com mais de 98 anos. Nhá Zéfa nasceu num sítio em Arujá (SP), época em que essa cidade ainda pertencia à Mogi da Cruzes, e ao se casar foi morar num grande terreno localizado no centro de Mogi. Por não ter título das terras, acabou sendo desapropriada e expulsa do lugar num período marcado pela gestão de um prefeito da ditadura militar. Nesse mesmo espaço, camadas de histórias estão sobrepostas. Hoje, se localiza o centro cívico da cidade com a prefeitura, o fórum, o corpo de bombeiro, o tiro de guerra, uma universidade privada, entre outros órgãos públicos. Aquele lugar é o epicentro telúrico das contradições da cidade. Sob o centro do poder institucional estão soterrados escombros de um passado recente.

Nhá Zéfa Onça, como era conhecida, era uma figura emblemática da festa do Divino de Mogi das Cruzes. Nhá Zéfa ainda está presente na memória coletiva da população. No ano de 2005, seus parentes (filhos, netos, bisnetos e tataranetos) desfilaram na entrada dos palmitos numa "ala" especialmente reservada para eles. 
Os familiares produziram uma camiseta com a foto da Nhá Zéfa estampada. Portanto, não há razões para pensar numa figura marginal, mas marginalizada por aqueles ligados à manutenção secular e religiosa do poder. Muitas pessoas comentam sobre a importância de Nhá Zéfa como referencial de devoção e, principalmente, de coragem, por isso o codinome "onça".

Todo ano a imprensa fala de Nhá Zéfa e de sua ausência na entrada dos palmitos. Uma questão inquietante é por que ainda se fala de Nhá Zéfa mesmo tanto tempo depois de sua morte. As pessoas perguntadas dizem que Nhá Zéfa era muito querida e batalhadora; todos gostavam dela. O que mais se ouve é que era uma grande devota, uma pessoa de bom coração e caridosa. Costumava participar de todos os momentos da festa do Divino, mas a entrada dos palmitos era a situação sublime. Ficava toda garbosa durante o desfile e depois fazia questão de comer o "afogado". Na entrada dos palmitos, desfilava com um cavalo enfeitado de um jeito peculiar com flores de papel colorido. Mesmo não tendo mais cavalo, desfilou com um emprestado. Quando não conseguiu desfilar a cavalo (por conta da idade), saiu com uma charrete. Foi durante muito tempo o centro das atenções e até hoje se fala muito de sua figura; há uma associação direta entre Nhá Zéfa e a própria festa do Divino.

A devoção de Nhá Zéfa ao Divino Espírito Santo começou cedo. Desde menina vinha da roça com a mãe para assistir à alvorada e participar de outros eventos da festa. A mãe se chamava Laurinda Maria do Espírito Santo, motivo que fazia Nhá Zéfa dizer que sua ligação com o divino vinha de família.

Nhá Zéfa era uma figura bastante conhecida na cidade de Mogi das Cruzes para além dos dias da festa do Divino. Vivia numa casa simples num terreno amplo onde cultivava árvores frutíferas e criava diversos tipos de bichos como cavalos, porcos, cabritos, galinhas e muitos cachorros. Gostava de preparar seus cozidos em fogão de lenha e tomava banho no rio Tietê, cujas águas eram limpas. 
$\mathrm{Na}$ época de sua juventude era muito namoradeira, por este motivo as mulheres de Mogi das Cruzes não a viam com "bons olhos". Teve muitos filhos. Dos cinco filhos conhecidos, apenas dois estão vivos. É provável que tenha tido mais filhos, mas isso não é confirmado. Foi casada apenas uma vez e ficou viúva ainda jovem. Ao longo da vida, teve muitos companheiros, todos mais jovens. O que mais permaneceu junto com ela foi um rapaz chamado Luis Galdino. Além dele, houve muitos outros que foram passando; alguns morriam, outros ela mandava embora. Há histórias em que Nhá Zéfa aparece roubando os maridos das outras mulheres, mas acontecia o contrário; ela ficava furiosa quando alguma mulher assediava o seu principal companheiro, Luis Galdino. Uma coisa é confirmada: ela brigava muito com todos os companheiros.

Além da festa do Divino, gostava de passar a noite dançando o São Gonçalo junto com um dos filhos. Era devota do Padre Donizette ${ }^{21}$ de Tambaú (SP). Todo ano juntava dinheiro para ir a Tambaú e sempre levava alguém para acompanhá-la. Viajava freqüentemente para Aparecida do Norte para visitar Nossa Senhora, mas também para pescar no rio Paraíba. Era devota de São Pedro e fazia uma grande festa junina todos os anos em sua casa com muita comida e cachaça (para os tocadores) durante três dias.

Muitas histórias são contadas sobre Nhá Zéfa. Uma delas diz que ela era uma mulher rica que perdeu tudo. Algumas pessoas dizem que ela era parente de Dona Yayá, esta sim uma mulher rica que morreu solitária. Como se sabe, Yayá não tinha sequer um único parente que pudesse herdar seus bens. A casa de Nhá Zéfa era próxima da imensa propriedade que Yayá tinha em Mogi das Cruzes, por isso é possível que haja essa associação entre a riqueza de Yayá (entregue à Universidade

\footnotetext{
${ }^{21}$ O Padre Donizette foi um sacerdote católico que hoje é cultuado como um santo popular no estado de São Paulo. Conhecido como o "santo caipira", teve seu processo de canonização aberto pelo Vaticano em 1996. Morto em junho de 1961, são atribuídos a ele inúmeros milagres. Atualmente, a cidade de Tambaú possui um calendário turístico religioso com direito à "semana Padre Donizette" e uma peregrinação, ao estilo Santiago de Compostela na Espanha, saindo de Tambaú em direção à Aparecida do Norte.
} 
de São Paulo por decisão judicial em 1968) e a suposta riqueza de Nhá Zéfa (tomada pelo prefeito da cidade nessa mesma época).

Outra história interessante diz respeito ao tipo físico de Nhá Zéfa. Dizem que ela era descendente dos índios Kayapó. É desnecessário dizer que nunca houve kayapó em São Paulo, porém, é inegável a origem cabocla de Nhá Zéfa - isso pode ser visto nas fotos - o que intriga é o fato de as pessoas usarem a imagem do índio kayapó como sinal de indigenidade.

Nhá Zéfa adorava viajar para lugares distantes e sozinha para pescar. Pescava também no rio Tietê. Às vezes, entrava no mato para buscar lenha e se perdia. Adorava animais e sabia muito bem como tratá-los (também benzia os animais). Não tinha medo de cobras. A relação com os animais era extremamente próxima. Uma das histórias contadas diz que um homem vinha montado num cavalo que empacou. O homem começou a chicotear o animal na tentativa de fazê-lo andar. Nhá Zéfa se aproximou e disse que não precisava fazer aquilo pois o cavalo estava apenas dor de barriga. Então, ela deu três voltas em torno do animal, disse algumas coisas e saiu. Daí em diante o cavalo sarou, o homem montou e partiu.

As pessoas com quem conversamos ressaltam que o grande prazer dela era mesmo mexer com animais. Não era ligada aos afazeres domésticos, mas se dedicava aos cuidados dos animais. Ela sabia exatamente como lidar com os bichos, mas definitivamente não gostava de lavar roupas. Contam que quando um vestido estivesse sujo ela simplesmente o jogava fora.

Era muito amiga de Zeca Franco, um sujeito que era dono de um sítio enorme em Mogi carregado de frutas. Em vida, Zeca Franco tinha ciúmes das frutas e brigava com quem tentasse pegá-las. Nhá Zefa, por ser amiga dele, era sempre bem recebida em sua propriedade. Conhecido por ser uma pessoa ruim e extremamente ciumenta, depois de morrer aparecia para aqueles que tentavam entrar em seu sítio para apanhar as frutas. Nhá Zéfa, porém, entrava e trazia para casa sacos carregados de frutas. As pessoas perguntavam como ela conseguia aquela 
façanha. Ela dizia que antes de entrar pedia licença para o homem, rezava e não simplesmente entrava e pegava as frutas. Nhá Zéfa não tinha medo de assombração porque sabia respeitá-la.

Era conhecida como benzedeira de crianças. Mas, ao mesmo tempo, contam histórias de que os pais assustavam os filhos dizendo que a mulher do cavalo buscaria quem não se comportasse direito. Esse tipo de história contada para amedrontar as crianças sobre a "mulher onça" são contadas em diversas partes do mundo e em Mogi das Cruzes não é diferente. Segundo Carlo Ginzburg (1988), durante a Idade Média se difundia a crença de que nas reuniões noturnas das seitas heréticas crianças e recém-nascidos eram devoradas por mulheres que se disfarçavam de animais.

Nhá Zéfa não gostava de ser chamada de onça e ficava brava quando isso acontecia. Em nossa pesquisa, apuramos que o apelido "onça" vem do primeiro marido, conhecido como João Onça, que era bandeireiro do divino e também caçava onças, inclusive tinha peles de animais nas paredes da casa. Como bandeireiro, o marido dela ia nas casas das pessoas com a bandeira do divino na busca de esmolas para a festa. Numa das casas onde tomou pouso acabou falecendo. Depois de sua morte, as pessoas passaram a chamar Nhá Zéfa de onça. Daí alguns dizem não haver ligação com o fato de ela ser uma mulher brava e corajosa.

Mesmo que o apelido de onça não tenha, num primeiro momento, a ver com a braveza, há histórias que confirmam o contrário. Um dos eventos interessante ocorreu num lugar chamado Ponte Grande. Voltando para casa a cavalo, ao passar em frente a um bar, alguns homens mexeram com ela. Não gostando disso, retornou, desceu do cavalo e chicoteou os dois homens que fugiram às carreiras. Nhá Zéfa era, de fato, uma mulher muito corajosa e ficava facilmente brava com os outros por uma série de motivos. Outro fato ocorrido foi ao defender a filha que vendia batata doce assada nas feiras livres da cidade. Nhá Zéfa queria ajudar a filha e saiu com o cesto carregado de batatas. Ao passar com o cesto, algumas pessoas 
mexeram com ela dizendo que a mulher onça tinha chegado. Ela respondeu que uma pessoa com nome de bicho jamais poderia ser batizada na igreja e, afora isso, disse vários palavrões para os japoneses da barraca de biscoito que pediram desculpas prontamente.

Lévi-Strauss, em O cru e o cozido (1991), fala da posição que a onça ocupa entre os mitos de origem do fogo (culinária) e do tabaco. Segundo o mito, o homem roubou da onça o fogo e o segredo do manejo do arco e flecha. A onça, por sua vez, e desde então, passou a odiar o homem porque teve que caçar com os dentes e comer carne crua, enquanto o homem comia carne assada. Há variações em que a onça e o homem representam termos polares de oposição: um come cru e o outro cozido, mas a onça come o homem e o homem não come a onça. Então, segundo as variações do mesmo mito, o ponto de mediação entre os dois passou a ser a mulher que, em alguns momentos, tem o poder de se transformar em onça quando provocada. Desse modo, a mulher-onça não se constitui como um perigo real em si, mas os homens a temem. Em outra variação, a mulher-onça é a feiticeira, assusta as crianças e seduz o marido de outras mulheres. Na festa do Divino Espírito Santo, a mulher onça está para o vermelho (fogo) ao passo que Nossa Senhora está para o branco (pureza da virgem).

Nhá Zéfa ao mesmo tempo em que defendia os filhos, tinha uma relação extremamente distante desses. Há algumas histórias nebulosas que não são contadas abertamente como o rapto de um filho mais velho que só apareceu anos depois, já casado. Há, também, a história de uma filha, de cerca de quatro anos, morta num acidente quando Nhá Zéfa estava no período de "dieta", ou seja, no pósparto. Houve outros casos como esquecimento de filhos ou de crianças pequenas em lugares desconhecidos em que ela saía com as crianças e não lembrava onde as tinha deixado. Com os demais filhos era brava e severa, mas tinha um zelo especial pelas netas. Os filhos de Nhá Zéfa tinham o costume de tomar a benção da mãe e até 
beijavam suas mãos. Uma maneira de perceber quando estava brava com os filhos era o momento em que a benção não era respondida.

Nos últimos dias de vida conviveu com uma das filhas e com as netas. Mas exigia que o portão de entrada ficasse aberto para poder sair quando quisesse. Não gostava de se sentir presa. No tempo em que ficou sem companheiro, morou sozinha. Custou muito para morar com a filha e as netas. As pessoas enfatizam muito o seu espírito de liberdade.

No final da vida, sofria de diabetes, mas desconhecia a doença. Nhá Zéfa gostava de comer doce de goiaba. Num dos depoimentos gravados disse que adorava tubaína. Adorava comer comida forte ${ }^{22}$,como virado de feijão bem temperado. Gostava de torresmo de porco e de Coca-Cola. Quando ficou doente não queria comer mingau. Compreende-se, pois uma pessoa que passou a vida comendo farofa de torresmo, carne de porco e cozidos não se contentaria em comer uma comida fraca como mingau.

Depois de melhorar a saúde, saiu para ir à feira. Um dia, andando pela feira, tomou um copo de caldo de cana, teve uma crise, desmaiou e foi levada à Santa Casa. Não agüentava ficar internada e pedia para sair. Dois meses depois, em casa, após sofrer muito, faleceu. Dizem que até nos últimos momentos tentava se levantar para sair de casa. Pedia doces e Coca-Cola para as netas. O último pedido de sua vida foi um gole de Coca-Cola.

Nhá Zéfa foi uma mulher livre. Não tinha medo de nada e não fugia de uma briga. Durante sua vida fez tudo que queria fazer. Tinha coragem e enfrentava a tudo e a todos. Uma mulher bem diferente das mulheres da primeira metade do século XX (período de forte dominação masculina). Usava um lenço na cabeça e uma bolsa feita de calça jeans. Nhá Zéfa era uma figura marcante: andava a cavalo, tinha espírito de liberdade, cuidava das próprias coisas, dos bichos, não tinha medo de cobras, entrava em sítio assombrado, enfim, o contrário do que o ambiente

\footnotetext{
${ }^{22}$ As categorias "comida forte" e "comida fraca", discutidas por Carlos Rodrigues Brandão (1981), foram apresentadas no capítulo 3.
} 
patriarcal convencionou pensar sobre as mulheres que participam da festa do Divino, ou seja, uma dona de casa, igrejeira etc. Não teve um único marido, mas companheiros que passaram ao longo da vida. Um deles chegou a esfaqueá-la, deixando-a internada no hospital por alguns dias, mas não agüentou a internação e fugiu. Desceu da janela do hospital por uma "teresa" e saiu correndo pela rua dos fundos vestida de pijama branco, chegando a assustar uma pessoa que passava.

Todos os homens a respeitavam. Tempos atrás havia cavalhada na festa do Divino de Mogi das Cruzes. Nhá Zéfa era a única mulher, ainda jovem, que corria a cavalhada durante a festa que ocorria perto de onde ela morou (em que hoje encontra-se o prédio do INSS). Inclusive, uma de suas netas trabalhou no fórum durante o programa Frente de Trabalho do governo do estado. As pessoas comentavam que, no lugar de trabalhar ali, ela deveria era ser uma das proprietárias, pois sua avó morava naquele lugar e era dona daquela terra.

Quando menina, Nhá Zéfa vinha da roça para acompanhar a festa do Divino, pernoitava ao lado do império para participar das alvoradas. No último ano de vida, já não podendo mais acompanhar a festa, alguns devotos levaram a bandeira do divino em sua casa e um caldeirão de "afogado" para ela comer.

No dia em que ela morreu muita gente compareceu ao velório. A nota de sua morte foi publicada nas capas dos principais jornais da cidade. Um dia após sua morte, Nhá Zéfa virou nome de rua através de um decreto da Câmara Municipal de Mogi das Cruzes $^{23}$. Em meio às ruas com nomes de barões, coronéis, doutores, padres, majores, marechais, professores, vereadores, senadores, deputados, presidentes... surge Nhá Zéfa montada num cavalo debochando de todas essas figuras. Camadas soterradas de histórias da cidade são reveladas.

Como uma pessoa arredia à sociedade torna-se nome de rua? Conforme diz Margarida Maria Moura em artigo sobre a morte do rei do Rosário, "não deve

\footnotetext{
${ }^{23}$ A rua localiza-se no bairro Mogi Moderno, cujo CEP é 08717-640, porém, o sobrenome está fora de lugar, o nome da rua é Josefina de Camargo Franco e não Josefina Franco de Camargo, seu verdadeiro nome. Provavelmente, ninguém sabe de quem se trata, teria sido melhor colocar rua Nhá Zéfa.
} 
passar despercebido que na sociedade rural brasileira é na morte que se cristalizam os heróis dos fracos e humildes, que guiam e protegem sua gente; é com a morte que se gesta o exemplo para uma vida futura, permanente e - quem sabe - superadora" (1983, p.245).

Dizem que as pessoas que foram amedrontadas pelos pais na época em que eram crianças queriam ir ao velório para ver Nhá Zéfa. A imprensa compareceu ao velório. Nhá Zéfa está enterrada no Cemitério da Saudade. Em seu túmulo não há uma identificação específica, trata-se de um túmulo simples, pintado de branco com uma capelinha em cima. Ela foi enterrada com uma camisa vermelha da festa do Divino - esse era um pedido pessoal.

Arredia certamente não é o termo mais apropriado para falar de Nhá Zéfa. Talvez arredia em relação àquilo que não está no centro do poder, mas estruturalmente forte (o poder do fraco $^{24}$ ) e cuja imagem é carregada de tensões. Para João de Pina Cabra, “a marginalidade passa a ser encarada como a condição de pessoas, objetos, práticas e significados que são menos legitimados pela operação dos processos de poder simbólico. A condição liminar, por sua vez, passa a ser a condição dos fenômenos transformacionais, por referência a essa mesma operação de processos hegemônicos"' (1996, p.36).

A memória de Nhá Zéfa permanece porque teve uma vida parecida com a vida da maioria das pessoas, como a maioria das mulheres, ou seja, batalhadora, sofredora e gloriosa. Era muito devota do divino. Não há ninguém que não saiba quem é Nhá Zéfa.

Nhá Zéfa é também pensada e vista por outras pessoas não ligadas à festa do Divino, mas envolvidas com questões da cultura popular, do cinema e do carnaval da cidade etc.

\footnotetext{
${ }^{24}$ As principais características entre aqueles que representam o poder do fraco, segundo Turner (1974b), são: 1.) se situam nos interstícios da estrutura social; 2.) estão à margem dela; 3.) ocupam os degraus mais baixos da estrutura social.
} 
Na festa do Divino de 2004, foi exibido um filme dirigido por Pedro do Carmo Abib durante toda a quermesse. O documentário chamado “Divino Espírito Popular" traz relatos de devotos do Divino Espírito Santo e tem como fio condutor da história uma atriz que interpreta Nhá Zéfa a partir de descrições feitas por amigos e familiares. A atriz quis saber a cor do cavalo, a roupa que Nhá Zéfa usava, o lenço e a bolsa para confeccionar um figurino parecido. Com o auxílio de imagens e fotos, a atriz ensaiou o modo de Nhá Zéfa andar e a maneira como ela cavalgava e falava. Algumas pessoas acharam que a atriz era a própria Nhá Zéfa e se emocionavam ao vê-la. Diziam que Nhá Zéfa tinha voltado.

Em meados da década de 1980, um carnavalesco da cidade preparou um enredo sobre a Nhá Zéfa chamado "Os encantos da onça Josefa", que buscava a história dessa personagem desde a infância até os últimos anos. O enredo tinha a intenção de mostrar diversas fases de sua vida até chegar à época da festa do Divino. O carnavalesco nos contou que a idéia era começar o desfile com tons corde-rosa mostrando uma Nhá Zéfa doce, criança e adolescente, e também uma pessoa romântica que teve muitos homens. Depois viria a fase vermelha quando era então conhecida como brava, a mulher onça. A idéia era trazer os familiares e a própria Nhá Zéfa que ainda estava viva para desfilar, mas naquele ano não houve carnaval (coincidentemente o prefeito era o mesmo que a desapropriou tempos atrás e não liberou a verba para o carnaval daquele ano).

O carnavalesco explicou que o enredo de uma escola de samba é montado da seguinte maneira: primeiro, escolhe-se um tema, a partir disso monta-se o enredo. $\mathrm{O}$ enredo é algo bastante abrangente e nem sempre cabe tudo no samba-enredo cantado pela escola na avenida. O enredo é um grande texto dramático com começo-meio-fim que pode falar sobre uma pessoa, uma cidade, uma divindade, um segmento da natureza etc. As técnicas de montagem do enredo variam de acordo com o estilo de cada carnavalesco. Alguns tratam o enredo como um teatro, com primeiro e segundo ato, como um roteiro de filme ou uma novela cujos 
personagens são criados. No meio do enredo é possível achar brechas e condições para criação e colocar ficção no meio da história. No caso de Nhá Zéfa, então, teria uma primeira fase cor-de-rosa, mais doce, que faria uma ligação com a personagem onça. Para o carnavalesco, essa primeira fase seria a mais difícil porque as informações são imprecisas, nem mesmo os familiares sabem as datas e as histórias. O trabalho criativo do carnavalesco entraria aí porque a personagem da festa do Divino é conhecida por todos. A onça pensada para o enredo do carnaval seria uma onça esculpida em tons rosa, com ênfase no glamour da mulher Josefina Franco de Camargo.

O trabalho do carnavalesco se assemelha ao do bricoleur em que "os restos e as sobras de estruturas simbólicas que lhe são mais preciosas permanecem às margens de sua obra, escondidos nas dobras da cultura, em testemunho do inacabamento de suas 'soluções', configurando um acervo de coisas boas para fazer pensar" (Dawsey, 2005b, p.31, grifo do autor).

As cores da escola de samba na avenida variariam, portanto, do rosa ao vermelho correspondendo, na concepção do carnavalesco, a diversos assuntos, dentre eles a infância e a mulher onça da festa, e até mesmo de questões políticas. Aliás, por falar em política, o cenário político das décadas de 1960 e 1970 não era dos mais serenos. Ao mesmo tempo em que Nhá Zéfa era uma figura forte, na cidade de Mogi das Cruzes, assim como no resto do país, predominava o domínio de grupos políticos autoritários. Há nessas manifestações populares uma trama política em que se articulam diversos grupos de interesse, órgãos públicos, instituições e escolas ${ }^{25}$.

A “aparição" mais recentemente de Nhá Zéfa foi na festa do Divino de 2006 por meio de uma exposição realizada na Coordenadoria de Cultura de Mogi das Cruzes chamada "O povo e sua fé" cujas instalações traziam fotos, colagens, obras esculpidas com papel, artesanatos e textos explicativos sobre a festa do Divino e os sete dons. Entre esses elementos dispostos numa pequena sala ao som das músicas

${ }^{25}$ Sobre o envolvimento entre festa popular e política, ver os trabalhos de Alba Zaluar (1983) e de Carlos Rodrigues Brandão (1986). 
dos grupos de congadas e moçambiques, havia uma peça montada com um chapéu de palha que trazia o nome de Nhá Zéfa e um texto que ressaltava sua origem pobre e sua presença "marcante" na festa.

A Nhá Zéfa inserida na festa do Divino é uma pessoa bastante conhecida e respeitada, sobretudo no meio feminino que compõe a festa. Mas vale dizer que era uma mulher como qualquer outra. Chama a atenção, sem dúvida, o fato de ela nunca ter tido uma função específica, por nunca ter sido festeira, capitã do mastro ou uma amazona, nem mesmo uma cantora ou rezadeira, enfim, era uma mulher que andava num cavalo e que por sua própria força se inseriu e permaneceu. Esta é a chave da questão: quando alguns acham que foi por piedade ela se inseriu na festa, na verdade é o contrário, ela já estava inserida pela sua própria força. É interessante o processo de permanência dela na festa, assim como de outros personagens, que são um pouco mais anônimos. Nhá Zéfa saiu do anonimato, surgiu na festa montada num cavalo e se impôs.

Uma coisa importante de Nhá Zéfa é que sua imagem era conhecida em toda cidade para além da festa do Divino, não era uma personagem que surgia apenas na época da festa. Essa história das garras de onça ficou conhecida no dia a dia. Quando ela era abordada por crianças e homens que a provocavam, surgia uma Nhá Zéfa Onça. Em outros momentos, era uma mulher admirada por todos, sobretudo quando estava montada a cavalo na entrada dos palmitos, seu principal personagem.

Tinha o costume de permanecer sentada em frente à catedral de Mogi das Cruzes. Mesmo sem mendigar, as pessoas passavam e davam algum dinheiro a ela. Os padres nunca se meteram em sua vida. A figura com quem ela brigou foi o prefeito que a desapropriou. Esse prefeito mandou derrubar a casa e passar a máquina em tudo que tinha sobrado. Esse foi o seu maior inimigo em vida.

Portanto, é impossível distinguir a senhora Josefina da Nhá Zéfa Onça. Era tida por alguns como uma "feminista", uma mulher "pública", usava calças, 
montava a cavalo e participava da festa. Essas atitudes demonstravam aquilo que as pessoas chamavam de espírito de liberdade, de independência, de ser ela mesma. Nhá Zéfa sempre andava a cavalo pela cidade. Na entrada dos palmitos era uma figura esperada, uma personagem marcante com espaço reservado só para ela. Às vezes, desfilava vestindo um chapéu com rosas e um lenço, que também era usado no dia a dia. Tinha um figurino elaborado de uma forma bastante espontânea. Espontânea também era sua devoção ao divino; era uma relação toda particular e pessoal, sem muita ligação com a igreja.

Nhá Zéfa não era brava o tempo todo, mas tinha uns lampejos de braveza e ficava irritada por algum motivo. Algumas pessoas a chamavam somente de Nhá Onça, outras, sobretudo aquelas ligadas à festa, a chamavam de Nhá Zéfa. Chamá-la de Nhá Zéfa tinha uma conotação mais feminina e religiosa, chamá-la de onça, uma conotação mais masculina e patriarcal. No entanto, Nhá Zéfa Onça era a personagem completa. A história da onça não vem de uma denominação própria, foram as pessoas que passaram a chamá-la por conta do seu comportamento.

Nhá Zéfa, na nossa visão, representa o poder do fraco conforme diz Victor Turner (1974b), daquele que não tem voz o ano inteiro e que pode reinar soberano no cortejo da entrada dos palmitos, momento em que as populações oprimidas introduzem na cidade os frutos do seu trabalho. O poder do fraco concentra-se em figuras ou grupos em estado de liminaridade, cujo poder é capaz de revitalizar a sociedade. Para Turner, há uma “certa homologia entre a 'fraqueza' e a 'passividade' da liminaridade nas transições diacrônicas entre uma posição social e outra, e a inferioridade 'estrutural' ou sincrônica de certas pessoas, grupos e categorias sociais nos sistemas políticos, legais e econômicos. As condições 'liminares' e 'inferiores' estão freqüentemente associadas aos poderes rituais e à comunidade inteira, considerada como indiferenciada" (1974b, pp.122-123).

Nhá Zéfa representa esta condição na medida em que exprime uma série de inversões e coextensividade acerca da festa do Divino: uma mulher pobre, filha de 
agricultores, mãe de muitos filhos e casada com muitos homens. Nhá Zéfa era uma figura deslocada da oficialidade da festa, costumava não entrar na igreja, causava medo nas crianças, era acusada de ser prostituta pelas outras mulheres. Ao mesmo tempo, muitas pessoas lembram dela com saudade e até devoção. Para Leach, “estas criaturas marginais, ambíguas são especificamente creditadas com o poder de mediar entre os deuses e os homens. Elas são objetos dos mais intensos tabus; tabus ainda mais sagrados do que aqueles dos próprios deuses. Num sentido objetivo, em contra-distinção a uma teologia teórica, é a Virgem Maria, a mãe humana de Deus, que é o principal objeto de devoção da Igreja Católica" (1983, p.181).

\section{VIRGEM MARIA: A MÃE DOS FRACOS}

A Virgem Maria é Nossa Senhora da Conceição, da Anunciação, da Encarnação, das Dores, da Piedade, da Assunção, da Glória, da Lapa, de Lourdes, de Fátima, de Guadalupe, de Czestochowa, Aparecida e mais 120 outras invocações somente no Brasil. Todas essas Nossas Senhoras são representadas, através da iconografia, em seis fases: infância, em que aparece junto com as figuras dos pais, Ana e Joaquim; Imaculada, a virgem ainda jovem; Encarnação, que se refere à saudação do anjo Gabriel; Mãe, em que está com o menino Jesus nos braços; Paixão, ligada ao sofrimento de Jesus; e Glória, que é a glorificação após a morte e a coroação no céu.

Para o historiador Jaroslav Pelikan, "um dos mais profundos e persistentes papéis da Virgem Maria na história foi o de estabelecer um elo com outras tradições. A palavra latina empregada para designar um 'construtor de pontes' originou o termo pontifex, título sacerdotal do paganismo romano. Na forma pontifex maximus, 
tornou-se uma das expressões do culto ao divino imperador romano e, por essa razão, foi repudiado pelos imperadores cristãos, já no século IV" (2000, p.99).

Ao falar da Virgem Maria, inegavelmente, estamos diante de um símbolo multivocal com correspondência no judaísmo ${ }^{26}$, no islamismo, além do cristianismo, sobretudo no catolicismo em que Maria é adorada pelos fiéis.

Para o islã, Jesus é filho de Maria e não de Deus. A imagem de Maria está associada à de Maria Madalena, com a intuição de demonstrar que, longe de ser a Sagrada Mãe Virgem de Deus, Maria, a Mãe de Jesus, é, portanto, uma mulher pecadora. Porém, dos 114 capítulos (sūrahs) do alcorão (qur'ān) há um, o de número 19, dedicado exclusivamente a Maria, ou Maryam, que enfatiza o fato dela ser a virgem mãe de Jesus.

Na bíblia, o livro que traz mais informações sobre Maria é o evangelho de Lucas. Nele, é descrita a fecundação da Virgem Maria pela ação do Espírito Santo. A história se dá desse modo: a anunciação é feita pelo anjo Gabriel. Maria o indaga pelo fato de não viver com nenhum homem. A resposta do anjo é a seguinte: “O Espírito Santo virá sobre você, e a força do Altíssimo a cobrirá com sua sombra. Por isso, o Santo que vai nascer será chamado Filho de Deus" (Lc: 1, 35). A anunciação é um exemplo paradigmático de reflexão sobre o mistério do nascimento de Jesus Cristo através de uma concepção miraculosa pelo poder do Espírito Santo. O Espírito Santo seria o agente divino da graça santificadora. A festa do Divino Espírito Santo é entendida como uma festividade em comemoração à concepção de Jesus Cristo, portanto uma festa da fertilidade.

Para Pelikan, Maria "serviu como modelo de paciência, até mesmo de tranqüila passividade e inquestionada obediência" (2000, p.119). A idéia de serva de Deus aparece no evangelho de Lucas. Portanto, para o autor, "ela deveria ser

\footnotetext{
${ }^{26}$ Sabemos que a Virgem Maria não está presente no judaísmo, mas pensa-se, por exemplo, na figura da "mãe judia", sempre lembrada como superprotetora e excessivamente zelosa. No judaísmo não encontramos uma figura feminina com status divino como Maria. Há uma figura conhecida como Shechiná que aparece em momentos em que o povo judeu necessita de consolo. Além disso, há outras figuras como Ruth, Sara, Rebeca, Raquel e Léa, das quais descende o povo judeu e também Miriam, irmã de Moisés, a juíza e profetiza Débora, além da rainha Esther.
} 
considerada pelas mulheres como um modelo de como elas deveriam agir em sua submissa obediência a Deus, a seus maridos, ao clero e à hierarquia da Igreja" (p.120).

$\mathrm{Na}$ tradição cristã, as mulheres têm uma posição de mediadora. Para Edmund Leach (1983), no Brasil do século XVIII, a mariolatria se combinava com o colonialismo católico, pois os filhos mestiços eram puxados para as fileiras da elite. No caso do colonialismo protestante ocorreria o contrário, este tendia a rejeitar o mito do Nascimento Virgem, colocando os filhos bastardos para as camadas inferiores da sociedade hierarquizada. Mais um detalhe: não podemos esquecer que os cristãos, segundo a bíblia, são todos filhos adotivos de Deus por meio de Jesus Cristo, o filho legítimo.

O "nascimento virgem", discutido por Leach, trata da ignorância da paternidade biológica dos nativos australianos e das ilhas Trobriand, assim como a crença na Virgem Maria, ou seja, o pai nada teria a ver com o nascimento físico do filho. Para Leach, "a ignorância é uma coisa relativa, e obviamente somos todos ignorantes em algum grau, particularmente no que diz respeito ao sexo" (1983, p.123). Em relação ao nascimento da criança, há uma distinção entre o status legal e a substância. Segundo Leach, "no caso cristão, faz-se uma distinção cuidadosa entre o status legal de Jesus como um homem e a sua natureza essencial como um deus. Enquanto homem, ele é o filho legítimo de José, o marido de Maria, e, neste sentido legal, pertence à linhagem de Davi. Em contraste, a sua concepção foi o 'divino espírito santo', o qual penetrou o corpo de Maria por um caminho não-natural" (pp.127-128, grifos do autor).

Segundo Leach, "na teologia do Cristianismo não é suficiente que Jesus enquanto mediador seja ambiguamente humano e divino ao mesmo tempo, Maria tem também de funcionar como mediadora e precisa, portanto, ter características anômalas quando considerada como ser humano. E o que poderia haver de mais anômalo do que um ser humano sem pecado e uma mãe que é virgem?" (1983, 
p.128). Para Roberto da Matta, ao comentar o artigo de Leach, a virgem é a "única categoria de mulher capaz de poder engendrar o próprio Deus e, assim fazendo, colocá-lo entre nós. Entre os homens e Deus, então, é preciso uma Virgem Mãe para realizar a mediação entre o espiritual e o temporal, o divino e o humano, o eterno e o perecível" (1983, p.46).

Nossa Senhora, como mãe sofredora e figura mediadora, é o arquétipo, sobretudo para a igreja católica, de todas as mulheres. Assim, o casamento é tão sagrado quanto a virgindade. Daí a distinção entre a virgem e a prostituta, conforme aponta Leach. Para ele, a sexualidade de uma virgem é controlada pelos homens e seu poder reprodutivo está a serviço da sociedade, ao passo que a sexualidade de uma prostituta é controlada por ela própria, colocando em risco seus poderes reprodutivos. Nesse sentido, a historiadora Claudia Fonseca alerta para a necessidade de romper com o sistema vitoriano de classificação que divide as mulheres entre santas ou demônios, donas de casa ou mulheres da rua. Para a autora, é preciso "enxergar [as] dinâmicas sociais que driblam esses dois pólos" (1997, p.513).

Para Jaroslav Pelikan, “o paradoxo de Maria como a Mãe Virgem não apenas ilustrou como também modelou, efetiva e decisivamente, o paradoxo da visão católica ortodoxa da sexualidade, resumida na glorificação da virgindade, acima do casamento - e pela instituição da sacramento do matrimônio, mas não da virgindade. Como Virgem, Maria foi o singular e sublime paradigma de castidade. Ao mesmo tempo, como Mãe, ela foi singularmente 'bendita entre as mulheres', como afirmou Isabel, mas, especificamente, porque seria a 'Mãe de meu Senhor', nas palavras finais de Isabel. As tensões representadas por esse paradoxo se estenderam por grande parte da história do cristianismo e, principalmente, durante o esforço para definir o significado da moralidade e da vida cristã. A pessoa de Maria também foi de enorme importância para essa história" (2000, p.155). 
Para o historiador, "Maria foi vista como a única criatura capaz de purificar e fortalecer os pecadores, somente ela poderia ser um amparo contra as tentações do demônio; mas ela só poderia se conduzir desse modo pela mediação de Cristo pela humanidade. Portanto, a oração dos crentes deveria ser: 'com tua prece piedosa, fazes com que teu filho seja benigno para conosco' ou 'Nossa Senhora, Nossa Mediadora, Nossa Advogada, reconcilia-nos com teu Filho, intercede por nós junto a Ele e representa-nos diante Dele. Fazes isso, Mãe Bendita, pela graça que encontraste [diante de Deus], pela prerrogativa que mereceste, pela misericórdia do Cristo a quem deste à luz'"' (2000, p.180-181).

Nossa questão não leva em conta o debate travado entre feministas e teólogas cristãs que colocaram, de um lado, Maria como modelo de mulher inferiorizada e, de outro, de suprema dignidade da mulher. É preciso romper esse debate ideológico e entender o lugar ocupado por Nossa Senhora na sociedade. No México, por exemplo, a imagem de Nossa Senhora de Guadalupe representa, de corpo e alma, as contradições daquele país. La Morenita, como é chamada, se transformou em bandeira particular e não oficial dos mexicanos, cujo tema básico é a libertação. A situação irônica diz respeito à palavra "Guadalupe", identificada com a causa indígena, é de origem espanhola (nome de um santuário dedicado a Maria na província de Cáceres na Espanha). Nessa mesma direção, Nossa Senhora Aparecida pode ser vista como um símbolo nacional que sintetiza as contradições subjacentes à sociedade brasileira.

A formação de símbolos sociais, nos lembra Victor Turner (1974a), se dá a partir de conflitos e contradições. Nossa Senhora de Guadalupe, que apareceu para o índio Juan Diego, assim como Nossa Senhora Aparecida encontrada por três pescadores pobres no fundo do rio Paraíba são formas análogas de símbolos nacionais tanto no Brasil como no México. Para Dawsey, "figuras como essas, em que as oposições se encontram, transformam-se em símbolos capazes de unificar grupos que de outra forma estariam em conflito" (1998, p.25). Os símbolos, para 
Turner, unificam, dão ordem, coerência e sentido à vida social. Na sua concepção, os símbolos são sempre multivocais, ou seja, dizem coisas diferentes, significam coisas diferentes e, assim, articulam diferenças.

Segundo Rubem César Fernandes (1985), Nossa Senhora Aparecida é Rainha, é Senhora, é mãe. Aparecida é a imagem convertida de Nossa Senhora da Conceição, padroeira de Portugal desde 1640 por proclamação de D. João IV e confirmada como padroeira do império brasileiro por D. Pedro I. Em 8 de setembro de 1904, já no período republicano, foi coroada como Rainha do Brasil, sendo em 1930 declarada padroeira do Brasil pelo Papa Pio XI e oficializada em 31 de maio como Rainha e Padroeira do Brasil. Porém, somente em 1980, por conta da visita do Papa João Paulo II, em resolução da Conferência Nacional de Bispos do Brasil, o governo declarou feriado nacional o dia 12 de outubro. Para Fernandes, essa "nova posição de destaque sugeria uma sutil relação de continuidade e de mudança na soberania religiosa [e política] do país" (1985, p.26).

A disputa pela Virgem reflete, segundo Jaroslav Pelikan, uma certa "luta de classes". Pois, para alguns, o fato de pobres e humildes que são muitas vezes privilegiados pelo aparecimento da santa envolvia a manipulação do poder da igreja sobre a massa inculta. Para outros, a Virgem privilegia aqueles que se assemelham a ela. No México, o culto a Nossa Senhora de Guadalupe está ligado às condições de vida das populações indígenas nativas sob a dominação espanhola. Trata-se de uma auto-imagem feminina em oposição à dominação patriarcal. Para Pelikan, “os acontecimentos relativos à aparição da Virgem em Guadalupe, em 1531, estavam ligados às tensões que evidenciavam uma luta de classes, uma contenda racial e uma batalha pelo sincretismo religioso" (2000, p.243). E prossegue, “evidentemente, nessa luta também havia a questão do local da aparição estar identificado com uma divindade feminina nativa que os missionários cristãos espanhóis tentavam sufocar, mas que, então, parecia ter voltado a seus índios convertido sob o disfarce de Mãe de Deus" (pp.243-244). 
Para Fernandes, "no Brasil, o povo e o clero [e também o estado] nunca rezaram exatamente para a mesma imagem" (1985, p.26). Nossa Senhora é Conceição para a elite e Aparecida para o povo, sem esquecer que Conceição é também Mamãe oxum, a deusa das águas doces, e Iemanjá, a senhora do mar.

Para Victor Turner (1974a), o culto à Nossa Senhora de Guadalupe no México tem uma continuidade espacial com a mãe dos deuses Aztecas, ou seja, surgiu das cinzas do culto à Tonantzin. Para Turner, quando o poder da estrutura secular está nas mãos de um único grupo, sobretudo masculino e patriarcal, que se projeta como fonte de autoridade, legitimidade, garantia econômica e unidade estrutural do grupo surge, em contraposição, num nível social mais profundo, um sentimento de totalidade da comunidade, representado pelo poder do fraco, que irrompe através de figuras femininas e de símbolos maternos como Nossa Senhora e Nhá Zéfa cuja identificação com as pessoas simples é extrema.

\section{A VIRGEM E A ONÇA NO ESPELHO MÁGICO DA PERFORMANCE}

A antropologia da performance de Victor Turner (1987) nos ajuda a pensar a relação entre a Mulher Onça e a Mãe Virgem na medida em que pensamos nos espaços de transformações das pessoas, do ser e da consciência - na capacidade de ser outro em estado liminar, quando o "não-eu" vira "não não-eu". Os rituais também são transformadores - do lugar familiar ao lugar distante e o retorno ao familiar já transformado. Na festa do Divino Espírito Santo de Mogi das Cruzes, presenciamos momentos de transformações. A relação transformadora entre o Espírito Santo e a Virgem Maria, através de uma relação íntima, propiciou a concepção do Salvador. 
Nhá Zéfa (essa figura feminina encontrada em nossa etnografia) é a mulher, a mãe que vira onça, que vira Nossa Senhora na luta que se dá em torno da disputa pelo monopólio do sagrado. A onça Josefina (a mãe profana) diz muito sobre as esperanças depositadas na Mãe Virgem (a mãe santa protetora de todos).

O Espírito Santo é Deus, uma das três pessoas da Santíssima Trindade. Nossa Senhora foi o instrumento que trouxe o filho de Deus para o mundo. Mas ela é uma pessoa humana como todas as outras, uma pessoa que não conheceu o mal. Uma mulher igual às outras. Uma mulher como Nhá Zéfa. A diferença é que Maria foi dignificada porque foi a única que teve a graça de dar a luz ao filho de Deus. Trata-se de uma dignidade participada e não inerente. No meio de todas as mulheres, ela foi a escolhida para dar corpo ao filho de Deus, essa é a grande dignidade de Nossa Senhora.

Na perspectiva de olhar para as margens, Nhá Zéfa é Josefina, ou seja, o feminino de José, o esquecido (ou quase esquecido) marido da Virgem Maria. A história de José ainda não foi revelada na sua totalidade. Trata-se de uma história incompleta, silenciada. Pouco se sabe, pouco se fala dessa figura masculina envolvida no triângulo entre a Virgem, Deus e o filho nascido pela ação do Espírito Santo. José serve para evocar a história dos esquecidos ao mesmo tempo em que Nossa Senhora ocupa o lugar desse pai ausente. Em poucas palavras, “através do processo de performance, o contido e o suprimido revela-se" (Dawsey, 2005, p.163)

Há um parentesco entre Nhá Zéfa e Nossa Senhora na medida que ambas são símbolos multivocais. Nhá Zéfa Onça se aproxima a Nossa Senhora não como contraste dramático, mas como figura que emerge, conforme expressão de Carlo Ginzburg (1991), de sua “história noturna”. Para Ginzburg, está na mentalidade dos camponeses histórias de mulheres que cavalgam à noite, que falam com mortos, que curam moléstias de crianças, que são seduzidas e enganadas pelo demônio. O autor fala de história de mulheres que se disfarçavam de animais nas festas de Pentecostes em diversas regiões da Europa Medieval. 
Apesar das controvérsias, observamos aproximações entre Nossa Senhora e Nhá Zéfa. Uma última observação: etimologicamente, nhá e senhora são da mesma origem. Nhá é o mesmo que sinhá em próclise, ou até mesmo iaiá (tratamento dado pelos escravos a sua senhora). Nhá é sinônimo de senhora, que é sinônimo de "dona de casa", "esposa" ou de qualquer mulher que exerça poder e dominação. Nossa Senhora é a Virgem Maria, porém “Minha Nossa Senhora!” designa uma situação de espanto, de interrupção de uma ação. Com espanto (e admiração) são vistas as figuras arredias como Nhá Zéfa que poderiam ser um escândalo lógico para a liturgia católica, mas, no fundo, são fontes de vida para um grande número de pessoas que se sentem estruturalmente frágeis. Assim, os devotos do Divino Espírito Santo de Mogi das Cruzes olham para Nossa Senhora e vêem Nhá Zéfa.

Por vezes, usamos termos da arqueologia nessa dissertação. Por fim, acrescentaríamos que Nhá Zéfa provoca um abalo sísmico no interior da festa do Divino capaz de estremecer a ordem vigente e a aparente coerência lógica apresentada na superfície da cidade de Mogi das Cruzes. A questão é saber por que sua imagem insiste em permanecer. Nhá Zéfa resiste porque é uma semente que está hermeticamente fechada e que até hoje conserva as forças germinativas dos devotos do Divino Espírito Santo. 


\section{CONSIDERAÇÕES FINAIS}

Estar atento às elipses, incoerências, rasuras e emendas suspeitas para encontrar o que está submerso na superfície foi o objetivo desta dissertação. Buscamos retomar um tema bastante estudado e propor uma outra leitura acerca do catolicismo popular e de suas festas. A análise da festa do Divino Espírito Santo de Mogi das Cruzes demonstrou que isso é possível.

Em muitos momentos, o catolicismo brasileiro foi pensado em termos de uma religião oficial em contraposição a uma religião popular. A primeira estaria no plano de uma religião racional e ética - para usar termos weberianos - distinta da 
segunda que estaria mais próxima a um sistema irracional e não-ético. De qualquer modo, trata-se de um corte meramente formal.

O catolicismo brasileiro foi analisado de diversas maneiras. Para Duglas Teixeira Monteiro (1974), o catolicismo popular (também chamado de rústico) é marcado, de um lado, por uma indiferença aos sacramentos da igreja católica e, de outro, por um grande interesse pela festa. Outra característica importante seria a autonomia dos agentes do catolicismo rústico que se manifesta "através de práticas mágico-religiosas ligadas ao tratamento de moléstias, a recursos de autodefesa e proteção, e à tradição das festas dos padroeiros locais" (p.81). Para Maria Isaura Pereira de Queiroz (1973), o catolicismo popular é uma religião alegre e festiva. As relações familiares, de compadrio, as redes de vizinhança e de solidariedade são características fundamentais que marcam este tipo de catolicismo, conforme estudo realizado por Antônio Cândido (1982). Além disso, o culto aos santos está na base desse catolicismo. Segundo Sérgio Buarque de Holanda (1987), no catolicismo brasileiro as pessoas tratam os santos "com uma intimidade quase desrespeitosa" (p.109).

Para Roger Bastide (1971), os santos católicos foram incorporados ao que o autor chamou de "estrutura dualista brasileira" e usados como forma de legitimação dos valores culturais e das representações coletivas dos brancos. Os negros encontraram no catolicismo a existência de um Deus transcendente, mas para chegar ao divino supremo era preciso passar por intermediários como Jesus Cristo, a Virgem Maria e inúmeros santos cuja analogia com as divindades celestes do candomblé originou um sistema religioso sincrético. Os negros passaram a observar proibições, a guardar dias santos e a terem santos protetores (São Benedito e Nossa Senhora do Rosário). A magia, por sua vez, teve muita importância nesse processo de conversão ao cristianismo, ou "africanização" do catolicismo, sobretudo no panteão dos santos, nos seus sortilégios, nos poderes miraculosos de cura e nos ritos. Para Bastide, a magia está enraizada no catolicismo brasileiro, pois, para além das interpenetrações das religiões, já havia muita influência do catolicismo de Portugal cujo costume de juntar danças com máscaras e cantos profanos às práticas religiosas existia há muito tempo. 
Alba Zaluar (1983) entende o catolicismo popular como uma religião prática. A autora entende essa prática religiosa como uma linguagem que expressa as idéias dos agentes a respeito das oposições e complementaridades existentes entre as pessoas e os grupos sociais. Segundo a autora, o catolicismo popular é um "sistema de classificação para as coisas e os seres e uma interpretação para os acontecimentos diários e extraordinários que remete a uma concepção da ordem universal" (p.23).

A discussão de Zaluar está muito próxima às concepções de Pierre Bourdieu acerca da religião. Segundo o sociólogo francês, "a religião contribui para a imposição (dissimulação) dos princípios de estruturação da percepção e do pensamento do mundo e, em particular, do mundo social, na medida em que impõe um sistema de práticas e de representações cuja estrutura objetivamente fundada em um princípio de divisão política apresenta-se como a estrutura naturalsobrenatural do cosmos" (1999, pp.33-34).

No caso do catolicismo popular, segundo Alba Zaluar, a partir das reflexões de Bourdieu, há uma conjugação entre a magia e a religião, pois ambas constituem racionalização, ou seja, ambas possuem formulações ideológicas que justificam certas posições dentro da estrutura social. Diante desses dois pólos (magia e religião), a autora se pergunta como é possível estudar o catolicismo popular. Para ela, essa possibilidade está na exploração teórica das idéias de magia e religião como contribuintes para a imposição dos princípios de estruturação do pensamento que legitimam como naturais as divisões sociais. Portanto, não se trata de irracionalidade, mas de ilegitimidade diante daqueles que têm o monopólio do sagrado, dos que controlam o campo religioso e os bens de salvação. Zaluar entende o catolicismo popular brasileiro como uma linguagem, que não é apenas verbalizada, mas simbólica e cuja expressão são os rituais. Através dos símbolos, os atores envolvidos compreendem as noções de solidariedade, poder, dependência, reciprocidade, que muitas vezes legitimam o status quo. A autora compreende os símbolos como testemunhas não apenas do consenso, mas das contradições que mascaram as relações. Para ela, é preciso entender a lógica desse catolicismo como um sistema, sua racionalidade, sua coerência, suas categorias relativas aos símbolos e às práticas rituais. 
Em suma, segundo Alba Zaluar, o catolicismo popular brasileiro não é uma religião mistificadora (ou irracional). Nos termos de Pierre Bourdieu, trata-se de um sistema simbólico estruturado como qualquer outro que, eventualmente, contesta o monopólio dos bens de salvação. Em outras palavras, funciona como um veículo do poder simbólico e político, constrói uma experiência nos devotos ao mesmo tempo em que expressa e legitima a ordem do poder dominante, assumindo, enfim, uma função ideológica de legitimação de posições sociais.

O catolicismo popular pode ser melhor compreendido a partir daquilo que Clifford Geertz (1978) chamou de "sistema cultural", pois responde às situações limites como a vida e a morte, o sofrimento e a perda, enfim, confere inteligibilidade ao mundo e significado à existência dos homens nesse mundo "através da formulação de uma ordem de existência geral" (p.104).

De tudo que foi dito acima, preferimos falar em catolicismo barroco cuja matriz é erudita, mas suas principais características são a extravagância, a pompa, o exagero e a relação de proximidade com os santos de devoção. O próprio Divino Espírito Santo é transformado num santo, num ente que está próximo dos devotos. Não se trata de uma polarização entre oficial e popular, ricos e pobres, racional e irracional, mas de uma concepção cosmológica. O barroco, nas palavras de Maria Lúcia Montes, "significa a tradução de uma experiência de mundo marcada pela contradição que cinde sem separar totalmente e integra de modo precário duas metades indissociáveis de uma vivência ao mesmo tempo moderna e arcaica" (1998a, p.148).

Como falar em dois catolicismos (um oficial e outro popular) se quem empregou o catolicismo barroco foi a própria igreja católica no período colonial? Segundo a historiadora Martha Abreu, "as práticas católicas eram marcadas pelas espetaculares manifestações externas da fé, presentes nas pomposas missas, celebradas por dezenas de padres e acompanhadas por corais e orquestras; nos funerais grandiosos, nas procissões cheias de alegorias e nas festas, onde centenas de pessoas das mais variadas condições se alegravam com a música, dança, mascaradas e fogos de artifício" (1999, p.33). 
Carlos Rodrigues Brandão produziu um conjunto de trabalhos sobre a religiosidade popular e suas festas (além dos conhecidos estudos sobre hábitos alimentares e educação popular). $\mathrm{O}$ autor entende que a melhor maneira de compreender a cultura popular é através da religião. Para ele, a festa religiosa é uma forma coletiva e popular de troca entre o homem e a divindade e entre os próprios homens. Uma festa religiosa, sobretudo em sociedades rurais, é um acontecimento social de envolvimento coletivo que produz uma ruptura com a rotina seqüente da vida social. Desse modo, “é a si própria, seus valores, seus preceitos e sua história que ela revê, rememora e conserva" (1974, p.22).

Para Brandão, uma festa religiosa é um "campo oportuno de pedagogia da conservação da ordem social" (1987, p.153). No entanto, nossos dados etnográficos apontam para uma outra direção. Não estamos suficientemente seguros para dizer, ao modo de Roberto da Matta (1978), que procissões católicas e paradas militares reforçam a ordem social. Em campo, observamos que a festa revela brechas capazes de desconstruir o estado atual das coisas, de revitalizar e transformar a vida social. Portanto, não se trata de suspensão de conflitos em nome de uma coesão social, mas de algo rico em contradições e tensões. Uma antropologia da performance e da experiência diz que esperança está nas contradições.

Em Mogi das Cruzes, há uma tensão nas áreas identificadas com os agentes profanos que produzem a festa e as áreas de domínio da igreja católica. Os sacerdotes agem como representantes legítimos de manipulação do sagrado. Porém, identificamos uma afirmação constante do monopólio dos bens de salvação por parte da igreja conciliada às práticas religiosas tradicionais dos devotos. Podemos ver isso, por exemplo, quando o padre sai da sua paróquia para benzer o mastro ou os pedidos antes de serem queimados, quando as rezadeiras igualam o poder da bíblia ao da bandeira, quando Nhá Zéfa e outras mulheres são veneradas como santas, quando os devotos beijam a bandeira, tocam no festeiro, quando caminham nas madrugadas frias, caminham descalços nos cortejos, acendem velas ao pé do mastro etc. Tudo isso significa que, de alguma maneira, essas pessoas se apropriam e se deixam ser apropriadas pelo divino. Assim, humano e divino formam uma 
mesma substância. O catolicismo é vivido pelos devotos do Divino Espírito Santo como algo concreto, verdadeiro e pleno de sentidos.

Antes de colocar um ponto final nesse trabalho, seria interessante - como últimas palavras - realizar um esforço de sintetizar teoricamente as principais idéias discutidas ao longo dos capítulos apontando para o próprio limen do texto.

Buscamos olhar para a cidade de Mogi das Cruzes como uma trama de camadas sobrepostas. O mesmo pode ser dito sobre a disposição dos capítulos. Os dois primeiros capítulos estão próximos na medida em que dialogam acerca de um tema comum: o Divino Espírito Santo na história na cidade, no discurso sobre a tradição e nos atos de devoção. A festa do Divino em Mogi das Cruzes ocorre num cruzamento de diversos tempos históricos, de diferentes agentes e atores, de conteúdos, de valores e visões de mundo. Daí o fato de evidenciarmos tensões que se expressam nos momentos de interrupções e irrompem na superfície.

No catolicismo barroco, os agentes leigos têm grande importância. No entanto, mesmo que o festeiro e as rezadeiras tenham uma certa autonomia, os sacerdotes serão sempre os agentes legítimos de controle e autoridade do poder religioso. Entretanto, segundo Frazer, os feiticeiros, ao trocarem a magia pela religião, tornaram-se reis, mas conservaram o poder em insígnias de características mágicas como o cetro e a coroa que são em si a incorporação da divindade. $\mathrm{O}$ imperador do divino - o festeiro - é uma pessoa sagrada. Ele é a personificação da figura divina do imperador, mas quem é divino não é ele e sim o seu império, ou seja, aquilo que ele representa (Mello e Souza, 2002).

Há um diálogo entre a ereção do mastro e os palmitos introduzidos na cidade como uma relação de troca entre o divino e a terra como lugar de morada, de fertilidade e de subsistência; uma terra de trabalho que se transforma em terra de festa. Conforme vimos nos depoimentos dos devotos, os palmitos vinham em carros de boi e eram fincados nas ruas por onde passava a procissão. Hoje, os palmitos foram substituídos por crianças que são transportadas nos carros de boi. 
Os principais eventos da festa nos remetem à idéia de abundância. A quermesse não é somente comércio, as coisas vendidas têm sua alma, para usar as palavras de Mauss. Na festa, a questão da alimentação é central, não somente do ponto de vista da satisfação física da fome, mas da relação que o devoto estabelece com o divino, com a terra e os frutos da terra. Porém, essa mesma terra que dá os frutos para a manutenção da vida também engole os corpos dos antepassados.

A carne e os palmitos oferecidos podem ser entendidos como sacrifícios para o Divino Espírito Santo. Segundo Mauss, o sacrifício é um ato religioso (2001, p.166). A prestação total de tipo agosnístico é feita através de pagamentos em forma de alimentos. Vale lembrar que patlatch também significa alimento (Mauss, 1974). O deus agonizante é sacrificado, é "afogado" e ressuscita para dar vida. De modo que, se o sacrifício é, por definição, um ato religioso, não há nada de profano (ou folclórico) na entrada dos palmitos.

Comer o "afogado" é comer substancialmente a carne sacrificada, o alimento consagrado e santificado. Os alimentos comidos geram forças na luta contra o mal. Os palmitos demonstram força e o regime de troca estabelecido na festa. A entrada dos palmitos permanece viva até os dias de hoje porque é o único pedaço reconhecível da festa realizada no passado.

A entrada dos palmitos atravessa o centro da cidade porque "o próprio lugar da cena deve ser sagrado; fora de um lugar sagrado, a imolação não passa de um assassínio" (Mauss, 2001, p.162). As raízes dos palmitos são as raízes da cidade.

A imagem do palmito é evocada em razão de esperanças e promessas não realizadas no passado ("Não adorais a palmeira / a cruz haveis de adorar", dizia o verso de Anchieta). O que se busca na festa é o grande desejo de mudança. O Divino Espírito Santo evoca o final dos tempos, o dever de retribuir a graça alcançada, o desejo de transformar o mundo, de converter a escassez em abundância, da consagração da idade do Espírito Santo, do partilhar de todas as coisas do céu na terra e da realização da festa permanente no Reino de Deus.

O fogo do Espírito Santo afasta os malefícios e combate os demônios. Com o "ritual da fogueira", realizado ao final da vigília de Pentecostes, encerra-se um 
período que foi suspenso no sábado pela manhã e inicia-se um novo tempo; uma nova vida renasce como uma fênix das cinzas da fogueira.

Dos olhos da onça Nhá Zéfa irradiam luzes subterrâneas que iluminam Nossa Senhora. Nossa Senhora é o símbolo maior que assimila outras imagens. É uma figura que está acima de todos os santos. Nossa Senhora é evocada como a mãe das mães. Mas não só as imagens de Nossa Senhora e Nhá Zéfa são lembradas. Figuras femininas como as rezadeiras, as "abelhinhas", as "divinetes", as "cafezeiras" e outras personagens maternas que já morreram são vistas como santas. Essas mulheres têm uma relação muito próxima com Nossa Senhora; elas conversam, trocam conselhos e até brigam. Ouvimos em vários momentos a assertiva de que Nossa Senhora é a esposa do Espírito Santo. A explicação é simples: quem fecundou a Virgem Maria foi o Espírito Santo!

Assim como os dois primeiros capítulos estão próximos, os dois últimos também dialogam na medida em que Nhá Zéfa : Palmitos :: Nossa Senhora : Pentecostes ${ }^{(-1)}$. Esse tipo de homologia permite compreender o modo como o universo é ordenado. Elementos não resolvidos surgem como "iluminação profana" (Benjamin, 1985).

Portanto, a festa do Divino Espírito Santo de Mogi das Cruzes consiste em diversas festas sobrepostas umas às outras ao mesmo tempo. Não se trata de uma ordenação hierárquica, do folclórico ao religioso, do profano ao sagrado, mas de camadas que se interpretam conjuntamente. São festas que concorrem, rivalizam, interferem, complementam umas as outras existem num mesmo plano. No entrecruzamento de épocas, reúnem-se “alegorias de reminiscências" (Matos, 1998, p.43).

Como vimos no início (e ao longo) desse trabalho, a festa do Divino Espírito Santo de Mogi das Cruzes se mostra como uma bricolagem de tempos. Segundo Maria Lúcia Montes, “a festa barroca pode assim ser lida como um texto no qual a sociedade fala sobre si mesma por meio da ritualização dos valores que impregnam em profundidade o cotidiano de seus membros, tornando-se, portanto, índice privilegiado de mentalidade" (1998b, pp.104-105). 
Esta dissertação, que acaba ao final desse parágrafo, procurou mostrar que a imaginação do catolicismo barroco se constitui sobre planos sobrepostos na longa duração. O fato de os devotos do Divino Espírito Santo escolherem anualmente alguém do povo e coroá-lo como imperador significa que o sonho e as esperanças de uma vida em abundância ainda permanecem vivas. Segundo Walter Benjamin, “a memória é o meio daquilo que vivemos, assim como a terra é o meio dentro do qual jazem, soterradas, as cidade mortas. Quem pretende se aproximar do próprio passado soterrado tem de proceder como um homem que cava" (1997, p.239). Assim, com as palavras de Benjamin, encerramos esse trabalho. 


\section{REFERÊNCIAS BIBLIOGRÁFICAS}

ABREU, Martha. O Império do Divino: festas religiosas e cultura popular no Rio de Janeiro, 1830-1900. Rio de Janeiro: Nova Fronteira, 1999.

ANDRADE, Mário de. A Entrada dos Palmitos. Revista do Arquivo Municipal, São Paulo, v. 32, n. 3, 1937.

Danças dramáticas do Brasil. São Paulo: Livraria Martins, 1959.

Araújo, Alceu Maynard de. Cultura popular brasileira. São Paulo: Melhoramentos, 1973.

Folclore Nacional. São Paulo: Martins Fontes, 2004. 3 vol.

BAKHTIN, Mikhail. A cultura popular na Idade Média e no renascimento: o contexto de Français Rabelais. São Paulo: Annablume/Hucitec, 2002. 
BASTIDE, Roger. As religiões africanas no Brasil: contribuição a uma sociologia das interpenetrações de civilizações. São Paulo: Pioneira, 1971. Vol. 1.

BENJAMIN, Walter. Origem do drama barroco alemão. São Paulo: Brasiliense, 1984.

. Obras Escolhidas 1: magia e técnica, arte e política. São Paulo: Brasiliense, 1985.

. Obras Escolhidas 2: rua de mão única. São Paulo: Brasiliense, 1997.

BÍBLIA Sagrada: Edição Pastoral. São Paulo: Edições Paulinas, 1989.

BOLLE, Willi. Fisiognomia da metrópole moderna. São Paulo: Edusp, 1994.

BOURDIEU, Pierre. O poder simbólico. Lisboa: Difel, 1989.

A economia das trocas simbólicas. São Paulo: Perspectiva, 1999.

BRANDÃO, Carlos Rodrigues. Cavalhadas de Pirenópolis: um estudo sobre representação de cristãos e mouros em Goiás. Goiânia: Oriente/DEC, 1974.

. O divino, o santo e a senhora. Rio de Janeiro: Funarte, 1978.

Sacerdotes de viola: rituais religiosos do catolicismo popular em São Paulo e Minas Gerais. Petrópolis: Vozes, 1981a.

. Plantar, colher, comer: um estudo sobre o campesinato goiano. Rio de Janeiro: Graal, 1981b.

. A festa do santo de preto. Rio de Janeiro: Funarte, 1985.

. Os deuses do povo: um estudo sobre religião popular. São Paulo: Brasiliense, 1986.

O festim dos bruxos: estudos sobre a religião no Brasil. Campinas: Editora da Unicamp, 1987.

BRECHT, Bertolt. A Santa Joana dos Matadouros. In: Teatro Completo 4. Rio de Janeiro: Paz e Terra, 1990.

1991.

. Mãe coragem e seus filhos. In: Teatro Completo 6. Rio de Janeiro: Paz e Terra,

BRUNER, Edward; TURNER, Victor (Org.). The Anthropology of Experience. Urbana \& Chicago: University of Illinois Press, 1986. 
CABRAL, João de Pina. A difusão do liminar: margens, hegemonias e contradições na antropologia contemporânea. Mana: Estudo de Antropologia Social, v. 2, n. 1, p. 2557, abr. 1996.

CAMPOS, Jurandyr Ferraz de. A Festa do Divino em Mogi das Cruze: mais de trezentos anos de fé e tradição. S.l., s.d.

CÂNDIDO, Antônio. Os parceiros do Rio Bonito: estudo sobre o caipira paulista e a transformação dos seus meios de vida. São Paulo: Duas Cidades, 1982.

CASCUDO, Câmara. Dicionário do folclore brasileiro. São Paulo: Global, 2000.

DA MATTA, Roberto. Carnavais, malandros e heróis: para uma sociologia do dilema brasileiro. Rio de Janeiro: Zahar, 1978.

. Apresentação. In: DA MATTA, Roberto (Org.). Edmund Leach. São Paulo: Ática, 1983.

DAWSEY, John C. De que riem os "bóias-frias"? Walter Benjamin e o Teatro Épico de Brecht em carrocerias de caminhões. 1998. Tese (Livre-Docência) - Faculdade de Filosofia, Letras e Ciências Humanas, Universidade de São Paulo, São Paulo.

Nossa Senhora Aparecida e a Mulher Lobisomem: Benjamin, Brecht e o teatro dramático na antropologia. Ilha: revista de antropologia, v. 2, n. 1, dez. 2000.

De que riem os "bóias-frias"? Teatro Épico em carrocerias de caminhões. In: ABANNE, Reunião de Antropólogos do Norte e Nordeste, 8., São Luís-MA, 01 a 04 jul. 2003. GT 14: Performance, Drama e Sociedade. Anais da VIII ABANNE. [versão atualizada, mimeo, 2004].

. Victor Turner e a antropologia da experiência. Cadernos de campo, v. 14, n. 13, p. 163-176, 2005a.

. O teatro dos "bóias-frias": repensando a antropologia da performance. Horizontes Antropológicos, Porto Alegre, v. 11, n. 24, p. 15-34, jul./dez. 2005 b.

DEBRET, Jean Baptiste. Viagem pitoresca e histórica ao Brasil. Belo Horizonte: Itatiaia, 1989.

DESCOLA, Philippe. La nature domestique: symbolisme et práxis dans l'ecologie dês Achuar. Paris: Maison dês Sciences de L'homme, 1986.

DURKHEIM, Émile. As formas elementares da vida religiosa. São Paulo: Paulinas, 1989.

EISENSTEIN, Serguei. Reflexões de um cineasta. Rio de Janeiro: Zahar, 1969. 
. O sentido do filme. Rio de Janeiro: Jorge Zahar, 1990.

FAUSTO, Carlos. Banquete de gente: comensalidade e canibalismo na Amazônia. Mana: Estudo de Antropologia Social, v. 8, n. 2, p. 7-44, 2002.

FERNANDES, Rubem César. Aparecida: Nossa Rainha, Senhora e Mãe, Saravá!. Ciência Hoje, v. 4, n. 21, p. 24-31, nov./dez. 1985.

FONSECA, Claudia. Ser mulher, mãe e pobre. In: Del PRIORE, Mary (Org.). História das mulheres no Brasil. São Paulo: Contexto, 1997.

FOUCAULT, Michel. A arqueologia do saber. Petrópolis: Vozes, 1972.

GEERTZ, Clifford. A interpretação das culturas. Rio de Janeiro: Zahar, 1978.

Negara: o Estado-Teatro no século XIX. Lisboa: Difel, 1980.

O saber local. Petrópolis: Vozes, 2004.

GINZBURG, Carlo. Os andarilhos do bem: feitiçarias e cultos agrários nos séculos XVI e XVII. São Paulo: Companhia das Letras, 1988.

História noturna: decifrando o sabá. São Paulo: Companhia das Letras, 1991.

GODBOUT, Jacques T. O espírito da dádiva. Rio de Janeiro: Editora Fundação Getúlio Vargas, 1999.

GRINBERG, Issac. Folclore de Mogi das Cruzes. S.l., s.d.

HOLANDA, Sérgio Buarque de. Raízes do Brasil. Rio de Janeiro: José Olympio, 1987.

LEACH, Edmund. O nascimento Virgem. In: DA MATTA, Roberto. Edmund Leach. São Paulo: Ática, 1983.

LÉVI-STRAUSS, Claude. Antropologia estrutural. Rio de Janeiro: Tempo Brasileiro, 1967.

Introdução à obra de Marcel Mauss. In: MAUSS, Marcel. Sociologia e antropologia. São Paulo: EPU/EDUSP, 1974. Vol. 1.

. O cru e o cozido. São Paulo: Brasiliense, 1991.

. O pensamento selvagem. Campinas: Papirus, 1997.

. Tristes trópicos. São Paulo: Companhia das Letras, 1999. 
LÉXICO das Religiões. Petrópolis: Vozes, 1998.

MARTINS, José de Souza. Expropriação e violência: a questão política no campo. São Paulo: Hucitec, 1982.

A morte e os mortos na sociedade brasileira. São Paulo: Hucitec, 1983.

- Caminhada no chão da noite: emancipação política e libertação nos movimentos sociais do campo. São Paulo: Hucitec, 1989.

MATOS, Olgária. Drama Barroco: topografias do tempo. História Oral, n. 1, p. 43-59, 1998.

MAUSS, Marcel. Sociologia e antropologia. São Paulo: EPU/EDUSP, 1974. Vol. 1 e 2. Ensaios de sociologia. São Paulo: Perspectiva, 2001.

MELLO E SOUZA, Marina de. Reis negros no Brasil escravista: história da festa de coroação de Rei Congo. Belo Horizonte: Editora UFMG, 2002.

MONTERO, Paula. O problema da cultura na Igreja Católica contemporânea. Estudos Avançados, v. 9, n. 25, 1995.

Religiões e dilemas da sociedade brasileira. In: BARROS, Sérgio Miceli Pessoa de (Org.). O que ler na ciência social brasileira (1970-1995). São Paulo: Sumaré/ANPOCS/CAPES, 1999. Vol. 1.

MONTEIRO, Duglas Teixeira. Os errantes do novo século: um estudo sobre o surto milenarista do Contestado. São Paulo: Livraria Duas Cidades, 1974.

MONTEIRO, John. Negros da terra: índios e bandeirantes nas origens de São Paulo. São Paulo: Companhia das Letras, 1994.

MONTES, Maria Lúcia. Entre o arcaico e o pós-moderno. Sexta-feira, n. 2, 1998a.

. As figuras do sagrado: entre o público e o privado. In: NOVAIS, Fernando; SCHWARCZ, Lilia Moritz (Orgs.). História da vida privada no Brasil: contrastes da intimidade contemporânea. São Paulo: Companhia das Letras, 1998b.

MORAES, Fernando Oliveira. A Festa do Divino em Mogi das Cruzes: folclore e massificação na sociedade contemporânea. São Paulo: Annablume/FAPESP, 2003.

MORAIS FILHO, Melo. Festas e tradições populares do Brasil. São Paulo: Editora da Universidade de São Paulo, 1979. 
MOURA, Margarida Maria. A morte de um rei do Rosário. In: MARTINS, José de Souza. A morte e os mortos na sociedade brasileira. São Paulo: Editora Hucitec, 1983.

NISBET, Robert. História da idéia de progresso. Brasília: Editora Universidade de Brasília, 1984.

PASTA JR., José Antônio. Cordel, intelectuais e o Divino Espírito Santo: notas sobre artes do povo e estética da representação. In: BOSI, Alfredo. Cultura brasileira: temas e situações. São Paulo: Ática, 1999.

PELIKAN, Jaroslav. Maria através dos séculos: seu papel na história da cultura. São Paulo: Companhia das Letras, 2000.

PEREIRA, João Baptista Borges. Negro e cultura negra no Brasil atual. Revista de Antropologia, n. 16, p. 93-105, 1983.

QUEIROZ, Maria Isaura Pereira de. O campesinato brasileiro: ensaios sobre civilização e grupos rústicos no Brasil. Petrópolis: Vozes, 1973.

QUR'ĀN: Translation. London: Saheeh International, 1997.

RODRIGUES Filho, José Maria; CARLO Filho, José de. Mogi das Cruzes: das origens à Festa do Divino. S.l., s.d.

ROSENFELD, Anatol. O teatro épico. São Paulo: Coleção Buriti, 1965.

SÁEZ, Oscar Calonia. Fantasmas falados: mitos e mortos no campo religioso brasileiro. Campinas: Editora da Unicamp, 1996.

SAHLINS, Marshall. Cultura e razão prática. Rio de Janeiro: Zahar, 1979.

. Ilhas de história. Rio de Janeiro: Jorge Zahar, 1990.

. Cultura na prática. Rio de Janeiro: Editora da UFRJ, 2004.

SANCHIS, Pierre. Arraial: festa de um povo, as romarias portuguesas. Lisboa: Publicações Dom Quixote, 1992.

SCHECHNER, Richard. Between theater and anthropology. Philadelphia: University of Pennsylvania Press, 1985. Performance theory. New York: Routledge, 1988.

SCHWARCZ, Lilia Moritz. As barbas do Imperador: D. Pedro II, um monarca nos Trópicos. São Paulo: Companhia das Letras, 1998. 
SILVA, Rubens Alves. Performances congadeiras e atualizações das tradições "afrobrasileiras" em Minas Gerais. 2005. Tese (Doutorado) - Faculdade de Filosofia, Letras e Ciências Humanas, Universidade de São Paulo, São Paulo.

TAUSSIG, Michael. Xamanismo, colonialismo e o homem selvagem: em estudo sobre o terror e a cura. Rio de Janeiro, Paz e Terra, 1993.

TURNER, Victor. Dramas, Fields and Metaphors: Symbolic Action in Human Society. Ithaca and London: Cornell University Press, 1974a.

O processo ritual: estrutura e antiestrutura. Petrópolis: Vozes, 1974b.

From Ritual to Theatre: The Human Seriousness of Play. New York: PAJ Publications, 1982.

. The Anthropology of Performance. New York: PAJ Publications, 1987.

. Schism and Continuity in an African Society: A study of Ndembu Village Life. Oxford/Washington, D.C.: Berg, 1996.

Dewey, Dilthey e Drama: um ensaio em antropologia da experiência. Cadernos de Campo, v. 14, n. 13, p. 177-185, 2005.

ZALUAR, Alba. Os homens de Deus: um estudo dos santos e das festas no catolicismo popular. Rio de Janeiro: Zahar, 1983. 


\section{ANEXO I - PRINCIPAIS ORAÇÕES}

\section{Coroa do Divino Espírito Santo}

Deus, vinde em nosso auxílio.

Senhor, apressai-vos em socorrer-nos.

Glória ao Pai, ao Filho e ao Espírito Santo. Amém.

Primeiro Dom

Vinde Espírito de Sabedoria,

desprendei-nos das coisas da Terra

e infundi-nos o amor pelos coisas do Céu.

Vinde Espírito Santo, enchei os corações

de vossos fiéis e acendei neles o fogo do vosso amor.

Vinde e renovai a face da Terra.

(repete-se por sete vezes)

Ó Maria, que por obra do Espírito Santo

concebestes o Salvador,

rogai por nós.

\section{Segundo Dom}

Vinde Espirito de Entendimento,

iluminai a nossa mente com a luz da Eterna Verdade

e enriquecei-a de puros e santos pensamentos.

Vinde Espírito Santo... (por sete vezes, no final, Ó Maria)

\section{Terceiro Dom}

Vinde Espírito de Bom Conselho,

fazei-nos dóceis às vossas santas aspirações

e guiai-no no caminho da salvação.

Vinde Espírito Santo... (por sete vezes, no final, Ó Maria)

\section{Quarto Dom}

Vinde Espírito de Fortaleza,

daí-nos a força, constância e vitória nas batalhas

contra os nossos inimigos espirituais e corporais.

Vinde Espírito Santo... (por sete vezes, no final, Ó Maria)

Quinto Dom

Vinde Espírito de Ciência, 
sede o mestre de nossas almas e ajudai-nos

a praticar vossos santos ensinamentos.

Vinde Espirito Santo... (por sete vezes, no final, Ó Maria)

Sexto Dom

Vinde Espírito Santo de Piedade,

vinde morar em nossos corações,

tomai conta deles e santificai todos os seus afetos.

Vinde Espírito Santo... (por sete vezes, no final, Ó Maria)

Sétimo Dom

Vinde Espírito do Santo Temor de Deus,

reinai em nossa vontade e fazei que estejamos sempre

dispostos a antes sofrer e morrer que Vos ofender.

Vinde Espírito Santo... (por sete vezes, no final, Ó Maria)

\section{Senhor, Vem Dar-nos (cantado)}

Senhor, vem dar-nos Sabedoria / que faz ver tudo como Deus quis, / e assim faremos da Eucaristia / o grande meio de ser feliz.

Dá-nos, Senhor, esses dons, essa luz, e nós veremos que o Pão é Jesus!

Dá-nos, Senhor, o Entendimento / que tudo ajuda a compreender / para nós vermos como é alimento / o pão e o vinho que Deus quer ser.

Dá-nos, Senhor, esses dons, essa luz, e nós veremos que o Pão é Jesus!

Dá-nos, Senhor, o teu Conselho / que nos faz sábios para guiar: / homem, mulher, jovem e velho, / nós guiaremos ao santo altar.

Dá-nos, Senhor, esses dons, essa luz, e nós veremos que o Pão é Jesus!

Senhor, vem dar-nos a Fortaleza, I a santa força do coração. / Só quem vencer vai sentar-se à mesa: / para quem luta Deus quer ser pão.

Dá-nos, Senhor, esses dons, essa luz, e nós veremos que o Pão é Jesus!

Senhor, vem dar-nos Divina Ciência / que como o Eterno faz ver sem véus: / "Tu vês por fora, Deus vê a essência, / pensas que é pão, mas é nosso Deus".

Dá-nos, Senhor, esses dons, essa luz, e nós veremos que o Pão é Jesus!

Dá-nos, Senhor, Filial Piedade, / a doce forma de amar, enfim; / para que amemos quem, na verdade, aqui amou-nos até o fim.

Dá-nos, Senhor, esses dons, essa luz, e nós veremos que o Pão é Jesus!

Dá-nos, enfim, Temor Sublime / de não amá-los como convém: / o Cristo-Hóstia, que nos redime, I o Pai Celeste, que nos quer bem.

Dá-nos, Senhor, esses dons, essa luz, e nós veremos que o Pão é Jesus!

\section{Três Invocações a Maria Santíssima}

- Primeira invocação

Ó puríssima Virgem Maria, 
que pela vossa Conceição Imaculada, fostes pelo Espírito Santo transformado em tabernáculo predileto da divindade.

Rogai por nós, para que o Divino Paráclito venha, quanto antes, Renovar a face da Terra.

(Reza-se a Ave Maria)

- Segunda invocação

Ó puríssima Virgem Maria, que no mistério da encarnação, Vos tornastes, pela virtude do Espírito Santo, verdadeira Mãe de Deus.

Rogai por nós, para que o Divino Paráclito venha, quanto antes, renovar a face da Terra.

(Reza-se a Ave Maria)

- Terceira invocação

Ó puríssima Virgem Maria, que no Cenáculo, em oração com apóstolos, fostes repleta do Espírito Santo.

Rogai por nós, para que o Divino Paráclito venha, quanto antes, renovar a face da Terra.

(Reza-se a Ave Maria)

\section{Oração ao Divino Espírito Santo}

Vinde Espírito Santo,

enchei os corações de vossos fieis e acendei neles

o fogo do Vosso Amor.

Enviai o Vosso Espírito e tudo será

criado e renovareis a face da Terra.

Oremos:

Deus, que instruístes os corações

de vossos fiéis com a luz do Espírito Santo,

fazei que apreciamos retamente todas as coisas,

segundo o mesmo Espírito e gozemos sempre de sua consolação.

Por Cristo, Senhor Nosso. Amém.

\section{Oração a Nossa Senhora}

Senhor Jesus Cristo, filho de Deus Pai,

peco-vos enviar agora à Terra o Vosso Espírito.

Fazei que o Espírito Santo habite no coração de todos os povos,

a fim de que sejamos preservados da corrupção,

das calamidades e da guerra.

Seja a Senhora de todos os povos,

Maria Santíssima, a nossa advogada. Amém. 


\title{
ANEXO 2 - PRINCIPAIS MÚSICAS E CANTOS
}

\section{Folia do Divino}

(Mestre Ulisses de Sousa Morais - Biritiba Ussú, Mogi das Cruzes)

\author{
Abertura do Império \\ Deus vos salve, nobre Império \\ muito bem apreparado \\ onde está o Espírito Santo \\ no seu trono adorado. \\ Saída das alvoradas \\ Nóis saímos dos Império, nóis saímos dos Império \\ Nessa hora abençoada, Nóis saímos dos Império.
}

Fim da alvorada

Bendito louvado seja que já vem o claro dia

Nóis vâmo todos acompanhando o santo esposo de Maria... o santo esposo é de Maria.

Passeata das Bandeiras

Numa capela

Boa noite, meu senhor e também dona senhora.

Quem dá boa noite não sou eu é o Espírito Rei da Glória.

Meu Divino aqui chegou e nessa hora abençoada veio salvar o meu senhor e abençoar sua morada.

Meu Divino aqui chegou e nessa hora de alegria veio salvar o meu senhor e confortar sua família.

Divino Espírito Santo é o nosso pai da caridade que veio-lhe trazer saúde e muitas felicidades.

As imagens que aqui está e todas elas são sagradas e nóis dançai pra santa bença por a grande caridade.

Meu senhor dono da casa e licença queira a nóis dar o meu Divino vai embora e nóis queremo acompanhar.

\section{Numa casa}

chegada

Boa noite, meu senhor e também dona senhora.

Quem dá boa noite não sou eu é o Espírito Rei da Glória.

Abençoada foi a mão que acendeu aquela vela e há de ser abençoada e da bandeira donzela.

Meu Divino aqui chegou e nessa hora abençoada veio salvar o meu senhor e abençoar sua morada.

Meu Divino aqui chegou e nessa tão bonita hora veio salvar o meu senhor e também a dona senhora. 
Divino Espírito Santo é o nosso pai da caridade que veio-lhe trazer saúde e muitas felicidades.

Divino Espírito Santo é uma imagem muita sagrada e nóis dançai pra santa bença por a grande caridade.

Meu senhor dono da casa e licença queira a nóis dar o meu Divino vai embora e nóis queremo acompanhar.

Saída

Divino Espírito Santo, são a hora de agradecer e pra cantar tantas palavras do melhor que pode ser.

Deus the pague o bom lanche ai... que a nóis deu em boa hora e vóis será bem ajudado pelo Espírito Rei da Glória.

Deus lhe pague o bom lanche que deu pra nossa companhia e que o Divino lhe ajude toda hora e todo dia.

Vamos agradecer a oferta que deu pra esta bandeira... que deu pra esta bandeira.

E a de ser bem ajudada pelo espírito verdadeiro... o Espírito Rei da Glória.

Volta ao Império

Nóis cheguemo no Império

Nesta hora abençoada

Nóis vâmo receber a benção

Dessas bandeiras sagradas.

Fechamento do Império

Na chegada do Império, na chegada do Império

Fazêmo nossa oração... fazêmo nossa oração.

Ali está o Espírito Santo... o nosso pai da salvação... o nosso pai da salvação.

Algumas músicas dos grupos de congada e moçambique

Congada Nossa Senhora do Rosário, mestre Dico

Jesus Cristo deu a coroa, Nossa Senhora deu o véu.

Oh, oh Rainha, eu vou te levar pro céu

Moçambique de São Benedito e Nossa Senhora do Rosário, mestre José Tavares

Senhora Aparecida, Senhora da Conceição

Permita a Deus do céu abençoar esse chão

Senhora de Aparecida do seu manto azul anil

Permita a Deus do céu abençoar esse Brasil

Bendito louvado seja, bendito seja louvado

O Divino Espírito Santo, bom Jesus crucificado

Congada Santa Ifigênia, mestre Gislaine

Ô verde e branco hoje eu tenho certeza

Ô verde e branco hoje eu tenho certeza 
A bandeira de Santa Ifigênia é de Santa Tereza

Vamos com Deus, ô Virgem Maria

Com o Divino Espírito Santo, Santa Ifigênia é nossa guia

Congada São Benedito - Império de César, mestre Chico Preto

São Benedito é Deus no céu e nada mais, aí, aí, aí

A falsidade nesse mundo é muito grande

Por isso ele na terra não volta mais

Quem somos nóis pra viver entre o mal e o bem

Deus é maior e mais ninguém

São Benedito que fez a escada subiu pro céu de madrugada

São Benedito que fez a escada subiu pro céu de madrugada

Depois desceu do céu pra abençoar nossa congada

Depois desceu do céu pra abençoar nossa congada

\section{Bandeira do Divino}

(Ivan Lins e Vitor Martins)

Os devotos do Divino vão abrir sua morada / pra bandeira do menino / ser bem-vinda, ser louvada.

Deus nos salve esse devoto / pela esmola em vosso nome / dando água a quem tem sede / dando pão a quem tem fome.

A Bandeira acredita / que a semente seja tanta / que esta mesa seja farta / que esta casa seja santa.

Que o perdão seja sagrado / que a fé seja infinita / que o homem seja livre / que a justiça sobreviva.

Assim como os três Reis Magos / que seguiram a estrela-guia / a Bandeira segue em frente I atrás de melhores dias.

No estandarte vai escrito / que Ele voltará de novo / e o rei será bendito / Ele nascerá do povo.

\section{Eu navegarei}

Eu navegarei / no oceano do Espírito / E ali adorarei ao Deus do meu amor.

Espírito, Espírito que desce como fogo / Vem como em Pentecostes / E enche-me de novo.

Eu adorarei ao Deus da minha vida / que me compreendeu / sem nenhuma explicação.

Espírito, Espírito que desce como fogo / Vem como em Pentecostes / E enche-me de novo.

Eu servirei ao meu Deus fiel / ao meu libertador / aquele que venceu.

Espírito, Espírito que desce como fogo / Vem como em Pentecostes / E enche-me de novo.

\section{Vem Espírito Santo}

Vem Espírito Santo, vem! Vem iluminar! 
Nossos caminhos, vêm / iluminar.

Nossas idéias, vêm / iluminar.

Nossas angústias, vêm / iluminar.

As incertezas, vêm / iluminar.

Vem Espírito Santo, vem! Vem iluminar!

Toda a Igreja, vem / iluminar.

A nossa vida, vem / iluminar.

Nossas famílias, vêm / iluminar.

Toda a Terra, vem / iluminar.

Vem Espírito Santo, vem! Vem iluminar!

Os servidores, vem / iluminar.

Nossos pastores, vêm / iluminar.

A Diocese, vem / iluminar.

Todo o povo, vem / iluminar.

Louvemos nosso pai - Deus Criador.

Cantemos a seu filho - Libertador.

Unidos pelo Espírito - Consolador.

Vivamos todos juntos - no seu amor.

\section{A Nós Descei Divina Luz}

A nós descei, Divina luz,

A nós descei, Divina luz,

Em nossas almas acendei o amor, o amor de Jesus.

Vinde Santo Espírito / e do céu mandai / tua luz, um raio.

Vinde pai dos pobres / doador dos dons / luz dos corações / grão consolador / nossa alma habitais / e nos confortais.

Na fadiga, pouso / no ardor, brandura / e na tua dor, ternura.

A nós descei, Divina luz,

A nós descei, Divina luz,

Em nossas almas acendei o amor, o amor de Jesus.

Ó luz venturosa / que vossos clarões encham os corações / sem vosso poder / nada há no vivente / nada há de inocente.

Lavai o impuro / e regai o seco / curai o enfermo / dobrai a dureza / aquecei o frio / livrai do desvio.

A nós descei, Divina luz,

A nós descei, Divina luz,

Em nossas almas acendei o amor, o amor de Jesus.

Aos vossos fiéis / que confiastes oram / dai os sete dons / dai virtude e prêmio / e no fim dos dias / eterna alegria.

Aleluia, aleluia, aleluia, aleluia.

\section{Estaremos aqui reunidos}

Nós estamos aqui reunidos como estavam em Jerusalém / pois só quando vivemos unidos / é que o Espírito Santo nos vem.

Ninguém pára esse vento passando / ninguém e ele sopra onde quer / força igual tem o Espírito quando / faz a Igreja de Cristo crescer. 
Feita de homens a Igreja é divina / pois o Espírito Santo conduz / como o fogo que aquece e ilumina / que é pureza / que é vida / que é luz.

Sua imagem são línguas ardentes / pois amor é comunicação / e é preciso que toda as gentes saibam quanto felizes serão.

Quando o Espírito espalma suas graças / faz dos povos um só coração / cresce a Igreja onde todas as raças / um só Deus / um si Pai louvarão.

\section{Calix Bento}

Ó Deus salve o oratório / Ó Deus salve o oratório

Onde Deus fez a sua morada, oiá meu Deus / Onde Deus fez a sua morada.

Onde mora o cálix bento / onde mora o cálix bento / e a hóstia consagrada, oiá meu

Deus / e a hóstia consagrada.

De Jessé nasceu a vara / de Jessé nasceu a vara / da vara nasceu a flor, oiá meu Deus / da vara nasceu a flor, oiá meu Deus.

E da flor nasceu Maria / da flor nasceu Maria / de Maria o Salvador, oiá meu Deus / de Maria o Salvador, oiá.

\section{Deixa a Luz do Céu Entrar}

Tu anseias, eu sei bem, por salvação / tens desejo de banir a escuridão / abre pois de par em par seu coração e deixa a luz do céu entrar.

Deixa a luz do entrar / Abre bem as portas do teu coração / e deixa a luz do céu entrar.

Cristo, a luz do céu, em ti quer habitar / para as trevas do pecado dissipar / teu caminho e coração iluminar / e deixa a luz do céu entrar.

Deixa a luz do entrar / Abre bem as portas do teu coração / e deixa a luz do céu entrar.

Que alegria andar ao brilho dessa luz / vida eterna e paz no coração produz / Oh! Aceita agora o Salvador Jesus / e deixa a luz do céu entrar.

Deixa a luz do entrar / Abre bem as portas do teu coração / e deixa a luz do céu entrar.

\section{Segura na mão de Deus}

Se as águas do mar da vida quiserem te afogar / segura na mão de Deus e vai. Se as tristezas desta vida quiserem te sufocar / segura na mão de Deus e vai. Segura na mão de Deus / segura na mão de Deus / pois ela, ela te sustentará / não temas / segue adiante / e não olhes para trás / segura na mão de Deus e vai. Se a jornada é pesada / e te cansas a caminhada / segura na mão de Deus e vai. Orando, jejuando, confiando e confessando / segura na mão de Deus e vai. Segura na mão de Deus / segura na mão de Deus / pois ela, ela te sustentará / não temas / segue adiante / e não olhes para trás / segura na mão de Deus e vai. O Espírito do Senhor sempre te revestirá / segura na mão de Deus e vai. Jesus Cristo prometeu que jamais te deixará / segura na mão de Deus e vai. Segura na mão de Deus / segura na mão de Deus / pois ela, ela te sustentará / não temas / segue adiante / e não olhes para trás / segura na mão de Deus e vai. 


\section{Oração pela Família}

Que nenhuma família comece em qualquer de repente.

Que nenhuma família termine por falta de amor.

Que o casal seja um para outro de corpo e de mente.

E que nada no mundo separe um casal sonhador.

Que nenhuma família se abrigue debaixo da ponte.

Que ninguém interfira no lar e na vida dos dois.

Que ninguém os abrigue a viver sem nenhum horizonte.

Que eles vivam do ontem, no hoje em função de um depois.

Que a família comece a termine sabendo onde vai / e que o homem carregue nos ombros a graça de um pai / que a mulher seja um céu de ternura, aconchego e calor / e que os filhos conheçam a força que brota do amor.

Abençoa, Senhor, as famílias. Amém.

Abençoa, Senhora, a minha também!

Que marido e mulher tenham força de amar sem medida.

Que ninguém vá dormir sem pedir ou sem dar seu perdão.

Que as crianças aprendam no colo o sentido da vida.

Que a família celebre a partilha do abraço e do pão.

Que marido e mulher não traiam nem traiam seus filhos.

Que o ciúme não mate a certeza do amor entre os dois.

Que no seu firmamento a estrela que tem maior brilha.

Seja a firme esperança de um céu aqui mesmo e depois.

Que a família comece a termine sabendo onde vai / e que o homem carregue nos ombros a graça de um pai / que a mulher seja um céu de ternura, aconchego e calor / e que os filhos conheçam a força que brota do amor.

Abençoa, Senhor, as famílias. Amém.

Abençoa, Senhora, a minha também!

\section{Outros cantos cantados durante as missas da novena (sem títulos)}

(1)

Não há medo, incerteza ou cansaço / quando o Espírito Santo nos vem / quem temia, recobra seu passo / Quem calava, proclama / porém somos povo de Deus caminheiro / testemunhas do reino que vem / renovar corações por inteiro / não deixando de lado ninguém / toda a terra se vê transformada / quando o Espírito Santo nos vem / e a palavra de Deus é levada / aos cativos e aos pobres também / vida nova na Terra se faz / quando o Espírito Santo nos vem / a justiça é o caminho da paz / povo irmão / ninguém pisa ninguém.

\section{(2)}

Vem, vem, vem Espírito Santo / transforma minha vida / quero renascer / quero abandonar-me em seu amor / encharcar-me em seus rios, Senhor / derrubar as barreiras em meu coração. 
O pão da vida, a comunhão / nos une a Cristo e aos irmãos / e nos ensina abrir as mãos / para partir, repartir o pão / lá no deserto, a multidão / com fome segue o bom Pastor / com sede busca a Nova Palavra / Jesus tem pena e reparte o pão / na Páscoa a Nova da Nova Lei / quando amou-nos até o fim / partiu o pão e disso / "isto é meu corpo / por vós doado: tomai, comei / Se neste pão, nesta comunhão / Jesus por nós dá a própria vida / vamos também repartir os dons / doar a vida por nosso irmão / onde houve fome, reparte o pão / e tuas trevas hão de ser luz / encontrarás Cristo no irmão / será bendito do Eterno Pai / abri, Senhor, estas minhas mãos / que para tudo guardar se fecham / abri minh'alm, meu coração / para doar-me ao eterno dom.

(4)

Vim de longe de outras terras / pelo Espírito enviado / pelo Cristo separado / proclamar a salvação.

Cristo-Pão vem me sustentar / sua palavra é vida / para a vida iluminar / mas não lembro os sofrimentos / os açoites que ganhei / por amor ao meu irmão / esquecido do passado / vivo em Cristo meu presente / e me lanço para frente / para o Reino construir / neste peito meu de barro / para o homem desvalido / trago o Deus desconhecido / e a esperança do porvir / para o fraco sem defesa / para o pobre injustiçado / e o inocente acorrentado / anuncio libertação.

\section{Hino ao Divino Espírito Santo}

Vinde ó Espírito Santo.

Sobre a nossa oração.

Com o vosso divino encanto.

Dai-nos Santa inspiração.

Na terra e no céu.

Ressoa da Trindade.

O nome Santo é o da terceira pessoa.

Salve Espírito Santo.

Essa luz que é a Divindade.

Trouxe aos homens a consciência.

Criando a Paz e a Verdade.

Num Clarão de Inteligência. 